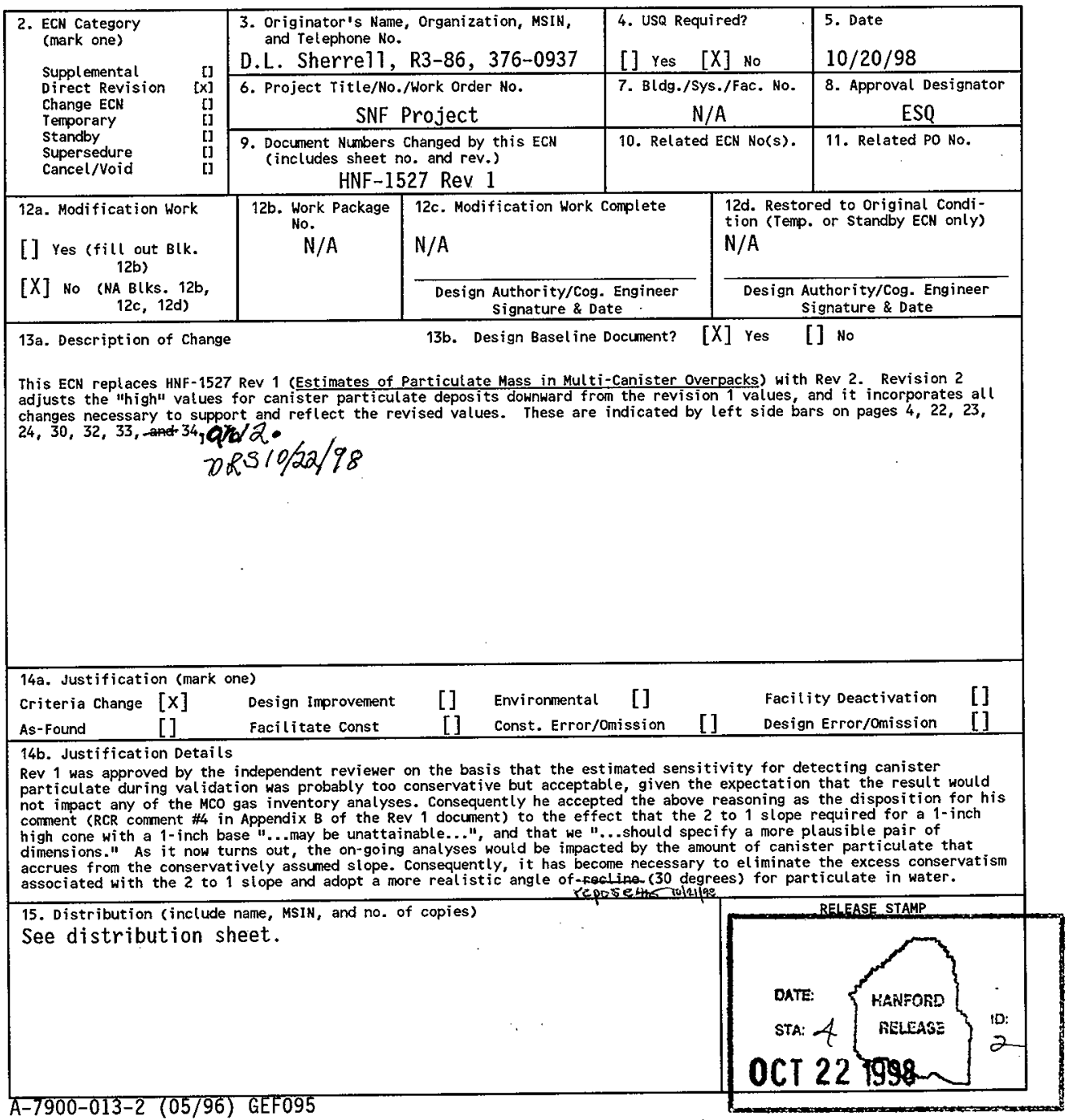




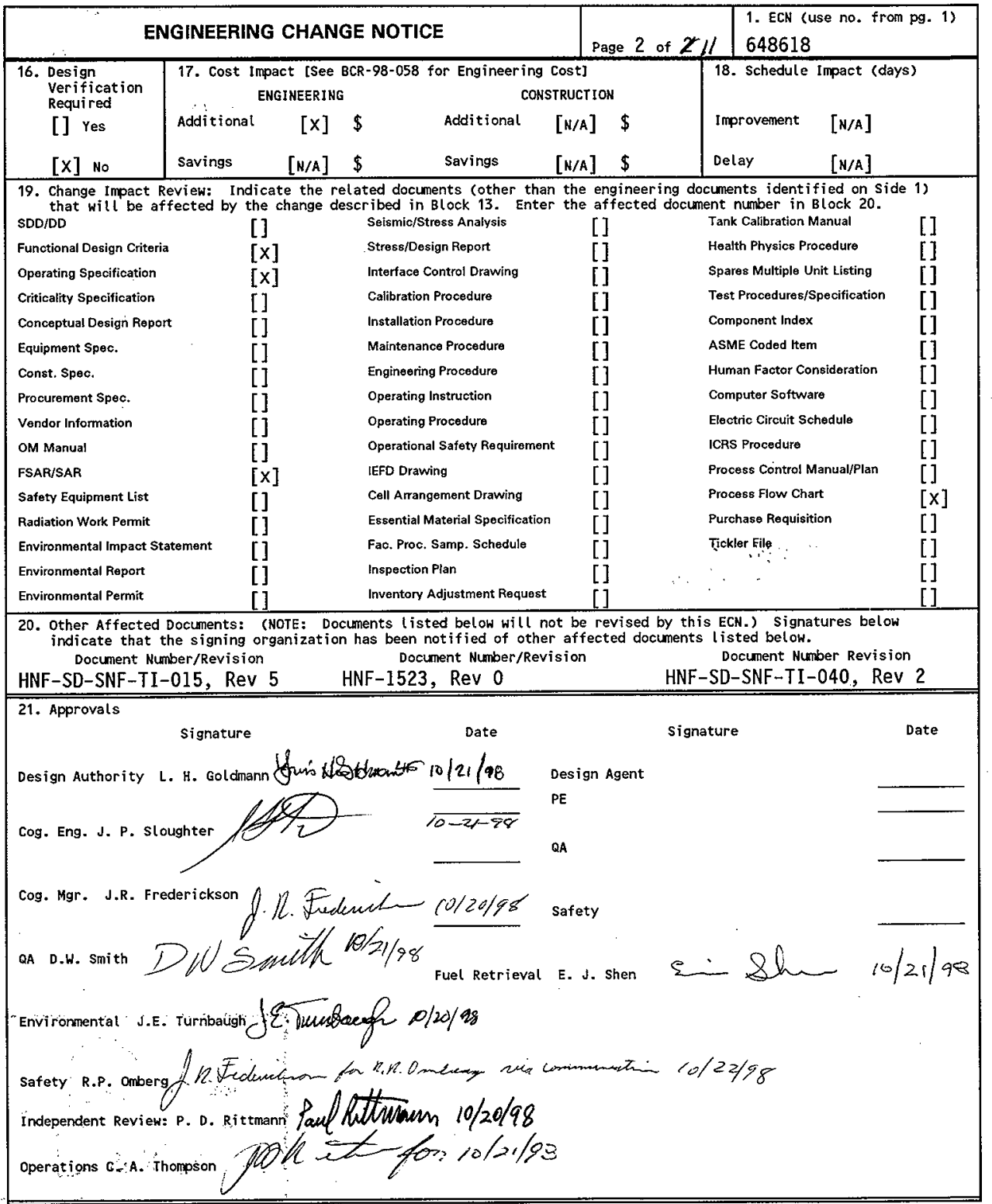


Table 2.2: Particulate Content of a Bounding MCO (See Note 1)

\begin{tabular}{|c|c|c|c|}
\hline PARTICULATE TYPE & PARTICULATE SOURCE & ESTIMATED PARTI CULATE MASS & REFERENCE FOR ESTIMATE \\
\hline $\begin{array}{c}\text { Cladding surface Film } \\
\text { (See note } 2 \text { ) }\end{array}$ & Residual After Cleaning & $9.5 \mathrm{~kg}$ & $\begin{array}{c}\text { Table } 6.1 \text {, Case } 3 \\
\text { (See note } 3 \text { ) }\end{array}$ \\
\hline Adhering Particulate & Residual After Cleaning & $18.8 \mathrm{~kg}$ & Table 6.1 , Case 3 \\
\hline $\begin{array}{c}\text { Canister Particulate } \\
\text { (See Note } 7 \text { ) }\end{array}$ & Residual After Cleaning. & 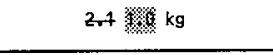 & $\begin{array}{c}\text { Table } 6.1 \text {, Case } 3 \\
\text { (See note } 4 \text { ) }\end{array}$ \\
\hline --ー- & Sub-Total & 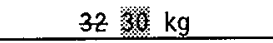 & ------n. \\
\hline Generated Particulate & $\begin{array}{c}\text { Corrosion by Basin Water } \\
\text { in Loadout Queue }\end{array}$ & $\begin{array}{c}7.5 \mathrm{~kg} \\
\text { (See note 5) }\end{array}$ & $\begin{array}{c}\text { HNF-SD-W441-CN-001 } \\
\text { (Sherrell 1998a) }\end{array}$ \\
\hline Generated Particulate & $\begin{array}{l}\text { Corrosion by MCo Water } \\
\text { During Transfer to CVDF }\end{array}$ & $\begin{array}{r}1.7 \mathrm{~kg} \\
\text { (See note 5) }\end{array}$ & $\begin{array}{l}\text { HNF-SD-W441-CN-001 } \\
\text { (Sherrell 1998a) }\end{array}$ \\
\hline Generated Particulate & $\begin{array}{l}\text { Corrosion by MCO Water } \\
\text { During Connection, MCO } \\
\text { Heat-Up, and MCO Draining }\end{array}$ & $\begin{array}{l}0.9 \mathrm{~kg} \\
\text { (See note 5) }\end{array}$ & $\begin{array}{l}\text { HNF-SD-W441-CN-001 } \\
\text { (SherretI 1998a) }\end{array}$ \\
\hline Generated Particulate & $\begin{array}{c}\text { Pre-Drain Corrosion } \\
\text { Cont ingency }\end{array}$ & $\begin{array}{c}4.9 \mathrm{~kg} \\
\text { (see note 5) }\end{array}$ & $\begin{array}{l}\text { HNF-SD-W441-CN-001 } \\
\text { (Sherrell 1998a) }\end{array}$ \\
\hline 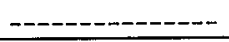 & Sub-Total & $15 \mathrm{~kg}$ & --------- \\
\hline Generated Particulate & $\begin{array}{c}\text { Corrosion by Water Vapor } \\
\text { During Post-Drain CVD } \\
\text { Operations }\end{array}$ & $6.5 \mathrm{~kg}$ & $\begin{array}{c}\text { HNF-3048 } \\
\text { (Sherrell 1998b) }\end{array}$ \\
\hline Generated Particulate & $\begin{array}{l}\text { Post-Drain Corrosion } \\
\text { Contingency for CVDF }\end{array}$ & $3.3 \mathrm{~kg}$ & $\begin{array}{c}\text { HNF-3048 } \\
\text { (Sherrell 1998b) } \\
\end{array}$ \\
\hline 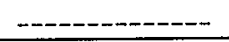 & Sub-Total & $9.8 \mathrm{~kg}$ & $-----\infty$ \\
\hline Generated Particulate & $\begin{array}{l}\text { Corrosion by Water Vapor } \\
\text { During Transport to cSB }\end{array}$ & $\begin{array}{c}1.5 \mathrm{~kg} \\
(\text { See note } 6)\end{array}$ & $\begin{array}{c}\text { HNF-3048 } \\
\text { (Sherrell 1998b) }\end{array}$ \\
\hline Generated Particulate & $\begin{array}{l}\text { Corrosion by Water Vapor } \\
\text { During Storage at CSB }\end{array}$ & $\begin{array}{c}7.3 \mathrm{~kg} \\
\text { (see note } 6 \text { ) }\end{array}$ & $\begin{array}{c}\text { HNF-3048 } \\
\text { (Sherrell 1998b) }\end{array}$ \\
\hline - - - - - - - - - - & $\begin{array}{l}\text { TOTAL BOUNDING } \\
\text { PARTICULATE MASS }\end{array}$ & 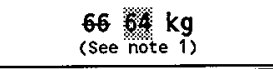 & -ーーー \\
\hline
\end{tabular}

Notes:

1) All estimates in this table are based on the Mco configuration used for Case 3 of Table 6.1 (2 scrap baskets and 3 fuel baskets), which represents a bounding total particulate inventory $M C O$.

2) While most fuel cladding films will contain no altminum hydroxide at all, the bounding value for cladding surface films is based on pure aluminum hydroxide. See section 5.2 .

3) No more than $9.5 \mathrm{~kg}$ of cladding $\mathrm{film}$ can be loaded into a bounding total particulate inventory MCO (i.e. an MCO with 2 scrap baskets \& 3 fuel baskets). However, the actual bounding estimate $(10.7 \mathrm{~kg}\rangle$ is listed under Case 1 ( 5 fuel baskets) of Table 6.1 because that case includes the most cladding.

4) While no more than 2.4 潾 $\mathrm{kg}$ of canister particulate can be loaded into a bounding total particulate inventory MCO, the actual bounding estimate for canister particulate $(3.5$. attributed to materiats that may lodge within fuel assembly flow channets, is listed under case 1 ( 5 fuel baskets) of Table 6.1 because that case includes the largest number of fuel assenblies.

5) Estimates for the particulate mass generated from corrosion of exposed uranium surfaces by water within the basin or MCO are based on results listed [by Table 2-2 of HNF-SD-W441-CN-001] for the mass of uranium metal corroded. The corresponding particulate estimates in this table are based on adjusting the uranium metal values by a factor of $270 / 238$ to reflect the difference between the atonic weight of uranium and the molecular weight of the assumed particulate form $\left(\mathrm{UO}_{2}\right)$.

6) No contingency was deemed necessary for transport to the CSB, nor for storage at the CSB, because those calculations were based on bounding assumptions and/or input data.

7) See Note 4 of Table 2.1. 


\subsubsection{Canister Particulate}

As discussed in section 4.3, deposits of canister particulate may be present in fuel assembly flow channels. This particulate is easily mobilized and is observed to $c$ loud the water when disturbed (note that most of it re-settles rapidly). Fuel handling and washing operations are designed to remove canister particulate from the fuel elements and fragments, including any accumulations within the assembly flow channels.

5.2.3.1 Scrap Basket. Because some scrap baskets will contain some complete fuel assemblies due to excessive damage on one or both ends, scrap baskets have the potential to retain canister particulate within fuel assembly flow channels. However, no canister particulate is allocated to scrap baskets (see Tables 5.1 and 6.1 ) because of the relatively large decrease in adhering particulate that will accompany the small amount of canister particulate that accrues as the high surface area scrap pieces are replaced by essentially intact, low surface area, fuel elements (i.e., it is regarded as a trade-off).

5.2.3.2 Fuel Basket. Accumulation of canister particulate within fuel assembly flow channels has only been observed on one occasion, and essentially none is expected to remain within the assemblies after cleaning (see section 4.3). However, given the relatively long, narrow flow channels within an intact fuel assembly, it must be assumed that there is some potential for a deposit to survive the cleaning process. Therefore, it will be necessary to establish an upper bound for deposits of canister particulate within freshly cleaned, intact fuel assemblies. This can be accomplished by developing an appropriate set of acceptance criteria for the fuel cleaning process validation testing activity (Shen 1997).

In conjunction with the overall fuel cleaning process validation testing protocol, the canister particulate removal criteria will provide a $99 \%$ confidence $_{3}$ (see section 5.2.3.2.1) that no fuel basket will contain more than $264 \mathrm{~m} \mathrm{~cm}^{3}$ of canister particulate.

After initial startup testing, a limited number of fuel canisters will be processed through the fuel cleaning machine while the operating parameters are controlled within defined ranges in order to validate the fuel cleaning process. Following completion of the validation testing, acceptable operation of the cleaning machine will be periodically confirmed on a sampling basis.

During validation testing and follow-on sampling, the inner element will be removed from the outer element of each freshly cleaned fuel assembiy, and both the outside surface and the bore of each element will be inspected to determine if the associated assembly passes a per-assembly cleaning criterion.

Based on the number of assemblies from a given canister that fail the perassembly cleaning criterion, the canister that contained them will either pass or fail a related per-canister criterion.

Finally, based on the number of canisters and/or individual assemblies that fail an overall test-batch criterion, the cleaning process either meets, or fails to meet, the cleaning process validation criteria for removal of canister particulate. If the validation criteria are not met, the cleaning machine operating parameters will be adjusted and the validation test will be repeated. The testing, adjusting, and re-testing must continue until the validation criteria are met prior to initiating routine operations. 
HNF-1527, ReV. 2 (OLS C:IWPDATA ...11527rv2b 10/20/98)

ECN 648518

Page 5 of $10 \%$

D $10 / 22 / 98$

The per-canister cleaning criteria basis utilizes the per-assembly cleaning criterion, based on a pre-defined number of canisters forming a canister batch in the process validation test:

- If one assembly in a canister fails the assembly cleaning criterion, then the canister fails the canister cleaning criterion, and there can be no more than one more assembly in the canister batch that fails the assembly cleaning criterion.

- If two assemblies in a canister fail the assembly cleaning criterion, then the canister fails the canister cleaning criterion, and no more assemblies in the canister batch can fail the assembly cleaning criteria.

- If three assemblies in a process validation test batch fail the assembly cleaning criteria, then the batch fails the process validation test.

The per-assembly process acceptance criterion is developed below, based on a process validation test batch size of 29 canisters. Meeting the overall process validation acceptance criteria (i.e., the per-assembly, per-canister, and per-test-batch criteria) with this batch size provides a $99 \%$ confidence that no more than $15 \%$ of the canisters will fail to meet the per-canister criteria.

The per-assembly cleaning criterion is based on defining the quantity of particulate observed to remain in flow channels after cleaning that would cause an assembly to be considered inadequately cleaned. The definition of an assembly that fails the per-assembly cleaning criterion is:

An assembly fails the cleaning criterion if, when removing the inner element from the outer element, and/or upon subsequent inspection of both elements, the total quantity of particulate observed is equivalent to a cone that is 1-inch in diameter (size of a quarter) at the base and 7 0. -inch high (eonservatively assumed for a worst case

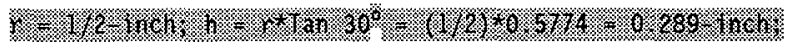

tess.

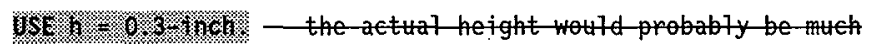

The volume of the above right circular cone is given by $V=1 / 3 * h * \pi * R^{2}$ where; $V=$ volume in $\mathrm{cm}^{3} ; h=$ height in $\mathrm{cm}$; and $R=$ radius of base in $\mathrm{cm}$;

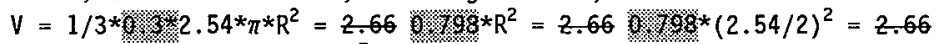

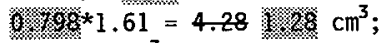

USE $\mathrm{cm}^{3}$.

The per-assembly cleaning criterion is designed to ensure that any assembly which satisfies it contains no more than $\mathrm{f} \mathrm{x} \mathrm{cm}^{3}$ of canister particulate, such that passing the process validation test provides a $99 \%$ confidence that no more than $15 \%$ of the canisters contain an assembiy that has retained over $\mathrm{cm}^{3}$ of canister particulate after undergoing the cleaning process. In addition, a passing canister batch (of 406 assemblies) can contain no more than two assemblies that have each retained over $6 \mathrm{~cm}^{3}$ of canister particulate. 
Failure of the assembly cleaning criteria is assumed to imply that each assembly flow channel contains a $3-i n c h(7.6 \mathrm{~cm})$ plug (average observed particulate depth in canisters [Pitner 1996]). Given the assumption that both flow channels are plugged, an assembly failing the cleaning criterion is estimated to contain $57 \mathrm{~cm}^{3}$ of canister particulate: $V_{\text {tot }}=V_{\text {inner }}+V_{\text {annulus }}$

I.D. of Inner $=1.22 \mathrm{~cm}($ Table 4.1$) ; R_{\text {jnner }}=1.22 / 2 \mathrm{~cm} ; \mathrm{h}=7.6 \mathrm{~cm}$; $V_{\text {inner }}=h^{*} \pi^{*} R^{2}=7.6 \mathrm{~cm} * \pi * R^{2}=23.88 \mathrm{~cm} *(1.22 / 2 \mathrm{~cm})^{2}=8.9 \mathrm{~cm}^{3}$

I.D. of Outer $=4.32 \mathrm{~cm}--R_{1}=4.32 / 2=2.16 \mathrm{~cm}$;

$0 . D$. of Inner $=3.25 \mathrm{~cm}-R_{2}=3.25 / 2=1.63 \mathrm{~cm}$;

$$
\begin{aligned}
& V_{\text {annulus }}=h^{*} \pi^{*}\left(R^{2}-R^{2}{ }^{2}\right)=23.88 \mathrm{~cm} *\left(2.16^{2} \mathrm{~cm}-1.63^{2} \mathrm{~cm}\right)= \\
& 23.88 \mathrm{~cm} *\left(4.67 \mathrm{~cm}^{2}-2.64 \mathrm{~cm}^{2}\right)=23.88 \mathrm{~cm} * 2.03 \mathrm{~cm}^{2}=48.5 \mathrm{~cm}^{3} \\
& V_{\text {tot }}=V_{\text {inner }}+V_{\text {annulus }}=8.9 \mathrm{~cm}^{3}+48.5 \mathrm{~cm}^{3}=57.4 \mathrm{~cm}^{3} ; \text { USE } 57 \mathrm{~cm}^{3}
\end{aligned}
$$

Based on the above, the allocation for canister particulate in flow channels for a batch of 29 canisters containing 406 fuel assemblies (29 canisters a 14 assemblies each $=406$ assemblies) can be expressed by the following terms:

- Volume of canister particulate within those assemblies that met the perassembly criterion is $1.3 \mathrm{~cm}^{3} \times 406$ assembles, or $1624526 \mathrm{~cm}^{3}$;

- Volume from those canisters (15\%) that could still contain one failed assembly, based on the statistics associated with a $99 \%$ confidence level on a 29 canister test batch, is $0.15 \times 29$ canisters per batch $\times 57 \mathrm{~cm}^{3}$ per assembly, or $248 \mathrm{~cm}^{3}$;

- Volume from the two assemblies that are allowed (by the per-test-batch criterion) to fail the cleaning criteria is $2 \times 57 \mathrm{~cm}^{3}$, or $114 \mathrm{~cm}^{3}$.

The maximum volume of canister particulate per batch of 406 assemblies is the sum of the above values: $1624 \mathrm{~s} 2 \mathrm{~cm}^{3}+248 \mathrm{~cm}^{3}+114 \mathrm{~cm}^{3}=198688 \mathrm{~cm}^{3}$. The maximum number of fuel assemblies that can be placed into one fuel basket is 54 (Smith 1998). Therefore the maximum volume of canister particulate that can be loaded into one fuel basket is $(54 / 406) *\left(198688 \mathrm{~cm}^{3}\right)=264 \mathrm{M} / \mathrm{K} \mathrm{cm}^{3}$. Given a bulk. density of $2.7 \mathrm{~g} / \mathrm{cm}^{3}$ (see section 4.7 .3 ) the high value for the canister particulate inventory of a fuel basket is $2.7 \mathrm{~g} / \mathrm{cm}^{3} \times 2641 \%$ $\mathrm{cm}^{3} /$ basket $=7133 \mathrm{~s} / 9 \mathrm{~g}$ USE $700329 \mathrm{~g}$. 


\subsection{RESULTING PARTICULATE MASS VALUES}

Calculations of particulate values are on an MCO basis shown below for three cases. Results are rounded to yield the overall values summarized in Table 6.1.

\subsubsection{Case 1: Zero Scrap Baskets - Five Fue1 Baskets}

1. Cladding Surface Film, Fuel

High: $3156 \mathrm{~cm}^{2} /$ assy * 270 assy $* 1.25 * 10^{-5} \mathrm{~kg} / \mathrm{cm}^{2}=10.65 \mathrm{~kg}$

Best Est: $3156 \mathrm{~cm}^{2} /$ assy * 270 assy * $3.54 * 10^{-6} \mathrm{~kg} / \mathrm{cm}^{2}=3.02 \mathrm{~kg}$

Calculation for Break Down by Film Type Reported in Table 6.1

A1 $(\mathrm{OH})_{3}: 3156 \mathrm{~cm}^{2} /$ assy*0.25*270 assy* $12.5 * 10^{-6} \mathrm{~kg} / \mathrm{cm}^{2}=2.663 \mathrm{~kg}$

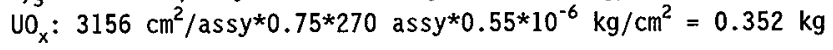

Low: $3156 \mathrm{~cm}^{2} /$ assy * 270 assy * $5.5 * 10^{-7} \mathrm{~kg} / \mathrm{cm}^{2}=0.47 \mathrm{~kg}$

2. Oxide Film, Fuel

High: $7900 \mathrm{~cm}^{2} /$ basket * 5 baskets $10 * 10^{-4} \mathrm{~cm} * 0.01 \mathrm{~kg} / \mathrm{cm}^{3}=0.395 \mathrm{~kg}$

Best Est: $425 \mathrm{~cm}^{2} /$ basket * 5 baskets $3 * 10^{-4} \mathrm{~cm} * 0.01 \mathrm{~kg} / \mathrm{cm}^{3}=0.0064 \mathrm{~kg}$

Low: $160 \mathrm{~cm}^{2} /$ basket $* 5$ baskets $3 * 10^{-4} \mathrm{~cm} * 0.01 \mathrm{~kg} / \mathrm{cm}^{3}=0.0024 \mathrm{~kg}$

3. Particulate on Fue $]$

High: $0.02 \mathrm{~kg} /$ assy * 270 assy $=5.40 \mathrm{~kg}$

Best Est: $0.0076 \mathrm{~kg} /$ assy * 270 assy $=2.05 \mathrm{~kg}$

Low: $0.0013 \mathrm{~kg} /$ assy $* 270$ assy $=0.35 \mathrm{~kg}$

4. Canister Particulate

High: 5 baskets $* .706 .3 \mathrm{~kg} /$ basket $=3.5 / \mathrm{kg}$

Best Est: 5 baskets $* 0.13 \mathrm{~kg} /$ basket $=0.65 \mathrm{~kg}$

Low: 5 baskets $* 0 \mathrm{~kg} /$ basket $=0 \mathrm{~kg}$ 
6. Particulate on Fuel

High: $0.02 \mathrm{~kg} /$ assy * 216 assy $=4.32 \mathrm{~kg}$

Best Est: $0.0076 \mathrm{~kg} /$ assy * 216 assy $=1.64 \mathrm{~kg}$

Low: $0.0013 \mathrm{~kg} /$ assy $* 216$ assy $=0.28 \mathrm{~kg}$

7. Canister Particulate

High: 4 baskets $* 0.7$ f.8. kg/basket $=2.801 \% 28 \mathrm{~kg}$

Best Est: 4 baskets $* 0.13 \mathrm{~kg} /$ basket $=0.52 \mathrm{~kg}$

Low: 4 baskets $* 0 \mathrm{~kg} /$ basket $=0$

\subsubsection{Case 3: Two Scrap Baskets - Three Fuel Baskets}

1. Cladding Surface Film, Scrap

High: $3156 \mathrm{~cm}^{2} /$ assy $* 78$ assy $* 1.25 * 10^{-5} \mathrm{~kg} / \mathrm{cm}^{2}=3.08 \mathrm{~kg}$

Best Est: $3156 \mathrm{~cm}^{2} /$ assy * 78 assy *3.54*10-6 $\mathrm{kg} / \mathrm{cm}^{2}=0.87 \mathrm{~kg}$

Calculation for Break Down by Film Type Reported in Table 6.1 Al $(\mathrm{OH})_{3}: 3156 \mathrm{~cm}^{2} /$ assy*0.25*78 assy* $12.5^{*} 10^{-6} \mathrm{~kg} / \mathrm{cm}^{2}=0.769 \mathrm{~kg}$

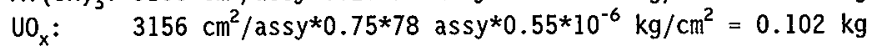

Low: $3156 \mathrm{~cm}^{2} /$ assy * 78 assy $* 5.5 * 10^{-7} \mathrm{~kg} / \mathrm{cm}^{2}=0.14 \mathrm{~kg}$

2. Cladding Surface Film, Fuel

High: $3156 \mathrm{~cm}^{2} /$ assy 162 assy $* 1.25 * 10^{-5} \mathrm{~kg} / \mathrm{cm}^{2}=6.39 \mathrm{~kg}$

Best Est: $3156 \mathrm{~cm}^{2} /$ assy 162 assy $* 3.54 * 10^{-6} \mathrm{~kg} / \mathrm{cm}^{2}=1.81 \mathrm{~kg}$

Calculation for Break Down by Film Type Reported in Table 6.1 Al $(\mathrm{OH})_{3}: 3156 \mathrm{~cm}^{2} /$ assy*0.25*162 assy* $12.5 * 10^{-6} \mathrm{~kg} / \mathrm{cm}^{2}=1.598 \mathrm{~kg}$

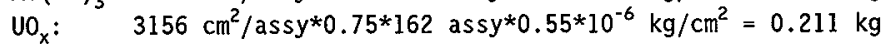

Low: $3156 \mathrm{~cm}^{2} /$ assy 162 assy $* 5.5^{*} 10^{-7} \mathrm{~kg} / \mathrm{cm}^{2}=0.28 \mathrm{~kg}$

3. Oxide Firm, Scrap

High: $45,000 \mathrm{~cm}^{2} /$ Basket*2 Baskets * $10 * 10^{-4} \mathrm{~cm}^{*} 0.01 \mathrm{~kg} / \mathrm{cm}^{3}=0.9 \mathrm{~kg}$ Best Est: $17,000 \mathrm{~cm}^{2} /$ Basket*2 Baskets $* 3 * 10^{-4} \mathrm{~cm}^{*} 0.01 \mathrm{~kg} / \mathrm{cm}^{3}=0.1 \mathrm{~kg}$

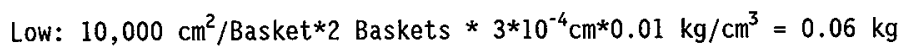


4. Oxide Film, Fuel

High: $7900 \mathrm{~cm}^{2} /$ Basket $* 3$ Baskets $* 10 * 10^{-4} \mathrm{~cm} * 0.01 \mathrm{~kg} / \mathrm{cm}^{3}=0.24 \mathrm{~kg}$

Best Est: $425 \mathrm{~cm}^{2} /$ Basket*3 Baskets $* 3 * 10^{-4} \mathrm{~cm} * 0.01 \mathrm{~kg} / \mathrm{cm}^{3}=0.004 \mathrm{~kg}$

Low: $160 \mathrm{~cm}^{2} /$ Basket $* 3$ Baskets $* 3 * 10^{-4} \mathrm{~cm} * 0.01 \mathrm{~kg} / \mathrm{cm}^{3}=0.001 \mathrm{~kg}$

5. Particulate on Scrap

High: $0.2 \mathrm{~kg} /$ assy $* 78$ assy $=15.60 \mathrm{~kg}$

Best Est: $0.02 \mathrm{~kg} /$ assy $* 78$ assy $=1.56 \mathrm{~kg}$

Low: $0.006 \mathrm{~kg} /$ assy $* 78$ assy $=0.47 \mathrm{~kg}$

6. Particulate on Fuel

High: $0.2 \mathrm{~kg} /$ assy $* 162$ assy $=3.24 \mathrm{~kg}$

Best Est: $0.0076 \mathrm{~kg} /$ assy * 162 assy $=1.23 \mathrm{~kg}$

Low: $0.0013 \mathrm{~kg} /$ assy * 162 assy $=0.21 \mathrm{~kg}$

7. Canister Particulate

High: 3 baskets $* 0.76 \mathrm{~kg} /$ basket $=2.100 .0 \% \mathrm{~kg}$

Best Est: 3 baskets $* 0.13 \mathrm{~kg} /$ basket $=0.39 \mathrm{~kg}$

Low: 3 baskets $* 0 \mathrm{~kg} /$ basket $=0$ 


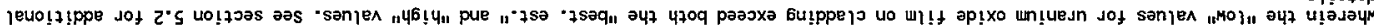

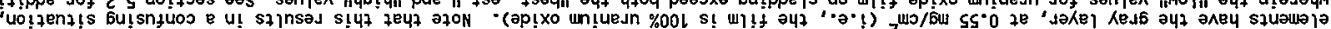

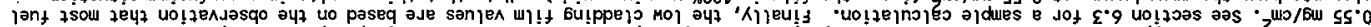

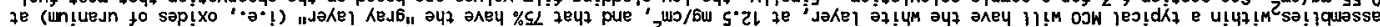

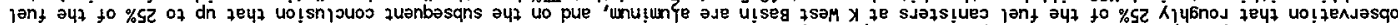

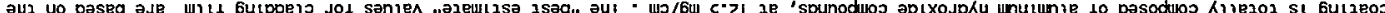

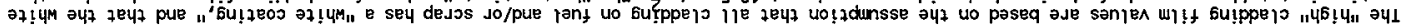

•əł!

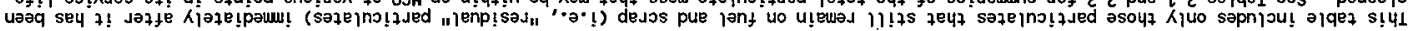

\begin{tabular}{|c|c|c|c|c|c|c|c|c|c|c|}
\hline I & 9 & 数器 & I & 9 & 97 & $\overline{\mathrm{I}}$ & 9 & 6 要 $\theta Z$ & \multicolumn{2}{|r|}{ (Б) 7H101 030NnOd } \\
\hline $9 I \cdot I$ & $96^{\circ} \mathrm{g}$ & 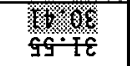 & $66^{\circ} 0$ & $\mathrm{G} 8^{\circ} \mathrm{G}$ & 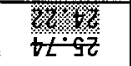 & $28^{\circ} 0$ & $2 L \cdot 9$ & $\begin{array}{l}\text { gigk } \\
96 \cdot 6 t\end{array}$ & & (6x) SSVW $7 \forall \perp 0 \perp$ \\
\hline 0 & $6 \varepsilon^{\circ} 0$ & 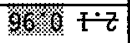 & 0 & $29^{\circ} 0$ & $8 \%$ 的 $8-7$ & 0 & $99^{\circ} 0$ & 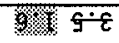 & [an] & \multirow{2}{*}{ 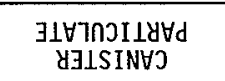 } \\
\hline 0 & 0 & 0 & 0 & 0 & 0 & 0 & 0 & 0 & denos & \\
\hline $12^{\circ} 0$ & $\varepsilon Z^{*} I$ & $\nabla Z^{\circ} \varepsilon$ & $8 Z^{\circ} 0$ & $79^{\circ} \mathrm{I}$ & $2 \varepsilon^{\circ} \dagger$ & $\mathrm{s} \varepsilon^{\circ} 0$ & $90^{\circ} 2$ & $0 t^{*} s$ & Lan」 & \multirow{2}{*}{ 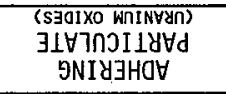 } \\
\hline$\angle t^{\circ} O$ & $99^{\circ} \mathrm{I}$ & $09^{\circ} \mathrm{SI}$ & $\varepsilon Z^{*} 0$ & $8 L^{\circ} 0$ & $08^{\circ} L$ & 0 & 0 & 0 & dedos & \\
\hline$\left[00^{\circ} 0\right.$ & 600.0 & $62 \cdot 0$ & $200^{\circ} 0$ & {$\left[0^{\circ} 0\right.$} & $2 \varepsilon^{\circ} 0$ & $200^{\circ} 0$ & $900^{\circ} 0$ & $0 t^{\circ} 0$ & 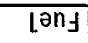 & \multirow{2}{*}{ 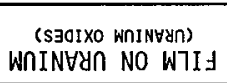 } \\
\hline $90^{\circ} 0$ & $1 \cdot 0$ & $6^{\circ} 0$ & $\varepsilon 0^{\circ} 0$ & $90^{\circ} 0$ & $9 b^{\circ} 0$ & 0 & 0 & $\overline{0}$ & dedos & \\
\hline $82^{\circ} 0$ & $\mathrm{IZ}^{\circ} \mathrm{O}$ & 0 & $8 \varepsilon^{\circ} 0$ & $82^{\circ} 0$ & 0 & $\angle B^{\circ} 0$ & $G \varepsilon^{\circ} 0$ & 0 & $\lfloor\partial)$ & \multirow{2}{*}{ 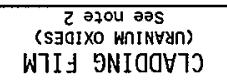 } \\
\hline$\nabla I^{\circ} 0$ & OL'O & 0 & $\angle 0^{\circ} 0$ & $90^{\circ} 0$ & 0 & 0 & 0 & 0 & dejos & \\
\hline 0 & $09^{\circ} \mathrm{I}$ & $6 \varepsilon^{\prime} 9$ & 0 & $\varepsilon I^{\cdot} Z$ & $\mathrm{IG}^{\circ} 8$ & 0 & $99^{\circ} 2$ & $99^{\circ}$ OI & lant & \multirow{2}{*}{ 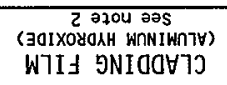 } \\
\hline 0 & $\angle L^{\circ} O$ & $80^{\circ} \varepsilon$ & 0 & $6 \varepsilon \cdot 0$ & $t \mathrm{~S}^{\circ} \mathrm{I}$ & 0 & 0 & 0 & denos & \\
\hline$M 07$ & $\perp S \exists 1 S \exists 8$ & HפIH & $\mathrm{MOT}$ & LSJ 1S & HSIH. & $\mathrm{MOT}$ & LSJ 1539 & H9IH & & \\
\hline$\underset{\text { coow }}{S \perp}$ & 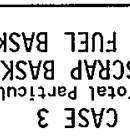 & $\begin{array}{l}\exists \exists y H \perp \\
0 M 1 \\
04 ! \text { sunos) }\end{array}$ & \multicolumn{3}{|c|}{ 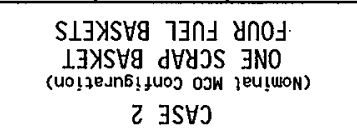 } & \multicolumn{3}{|c|}{ 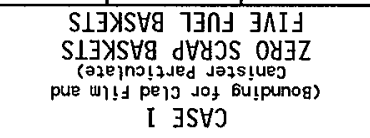 } & & \\
\hline
\end{tabular}

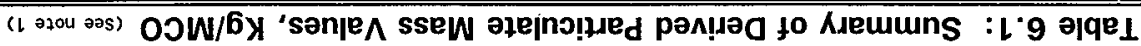




\subsection{SUMMARY}

High, best estimate, and low values are developed for particulate quantities (mass) and types (physical form and chemical make-up) within MCo baskets that have been loaded with freshly cleaned fuel assemblies and scrap. These per-basket estimates are then applied to all anticipated MCO payload configurations (Cases 1 through 3 of Table 6.1) to identify which configurations are bounding for each type of particulate.

The residual particulate material (i.e., particulate that may remain on and within freshly cleaned fuel) consists of films, which are found on the Zircaloy cladding and uranium surfaces, and particulate, which is found on and within the fuel assemblies and fragments.

The "high" values listed for cladding films under Case 1 of Table 6.1 are bounding for cladding films because the five fuel basket/zero scrap basket configuration of Case 1 contains the maximum possible cladding area. Case 1 al so represents the bounding "canister particulate" MCO because that particulate category is limited to materials that may lodge within fuel assembly flow channels, and because that case includes the largest number of intact fuel assemblies (i.e., flow channels). The Case 3 configuration is bounding for total particulates because its two-scrap-basket/three-fuel-basket payload contains the maximum possible exposed uranium area. The "best estimate" values listed under Case 2 are, by definition, "nominal" because Case 2 represents a typical MCO payload configuration (one scrap basket and four fuel baskets).

Finally the resulting bounding and nominal values for residual particulates are combined with corresponding values for particulates that may be generated by corrosion of exposed uranium after the fuel has been cleaned (Sherrel1 1998a/1998b). The resulting rounded nominal estimate for a typical MCO after 40 years of storage is $8 \mathrm{~kg}$ (see Table 2.1). The estimate for a bounding total particulate case $M C O$ is that it may contain up to $6664 \mathrm{~kg}$ of particulate after 40 years of storage (see Table 2.2). Note that the $18.8 \mathrm{~kg}$ of "adhering particulate" Tisted in Table 2.2 is intended to represent only materials that are very difficult to remove and, therefore, not readily available for release from an MCO (see the last paragraph of section 5.3 and the fifth paragraph of section 4.6). The same consideration applies to the table's $1.1 \mathrm{~kg}$ listing for oxide fitms on uranium. 


\title{
Estimates of Particulate Mass in Multi-Canister Overpacks
}

\author{
J. P. Sloughter \\ Numatec Hanford, Inc., Richland, WA 99352 \\ U.S. Department of Energy Contract DE-AC06-96RL13200 \\ EDT/ECN: 648618 \\ Org Code: $2 \mathrm{~F} 300$ \\ B\&R Code: EW7040000 \\ UC: 510 \\ Charge Code: 105355, BA40 \\ Total Pages: 62
}

Key Words: Multi-canister Overpack, MCO, Particulate, Adhering Particulate, Canister Particulate, Cladding Film(s), Oxide Film(s)

Abstract: High, best estimate, and low values are developed for particulate inventories within MCO baskets that have been loaded with freshly cleaned fuel assemblies and scrap. These per-basket estimates are then applied to all anticipated MCO payload configurations to identify which configurations are bounding for each type of particulate. Finally the resulting bounding and nominal values for residual particulates are combined with corresponding values [from other documents] for particulates that may be generated by corrosion of exposed uranium after the fuel has been cleaned. The resulting rounded nominal estimate for a typical MCO after 40 years of storage is $8 \mathrm{~kg}$. The estimate for a bounding total particulate case MCO is that it may contain up to $64 \mathrm{~kg}$ of particulate after 40 years of storage.

TRADEMARK DISCLAIMER. Reference herein to any specific comercial product, process, or service by trade name, trademark, manufacturer, or otherwise, does not necessarily constitute or imply its endorsement, recomendation, or favoring by the United States Government or any agency thereof or its contractors or subcontractors.

Printed in the United States of America. To obtain copies of this document, contact: Document Control Services, P.O. Box 950, Mailstop H6-08, Richland WA 99352, Phone (509) 372-2420;

Fax (509) 376-4989.
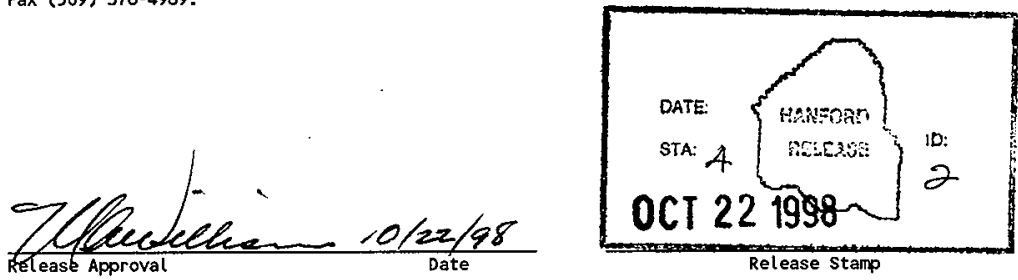

\section{Approved for Public Release}


(2) Title

Estimates of Particulate Mass in Multi-Canister Overpacks

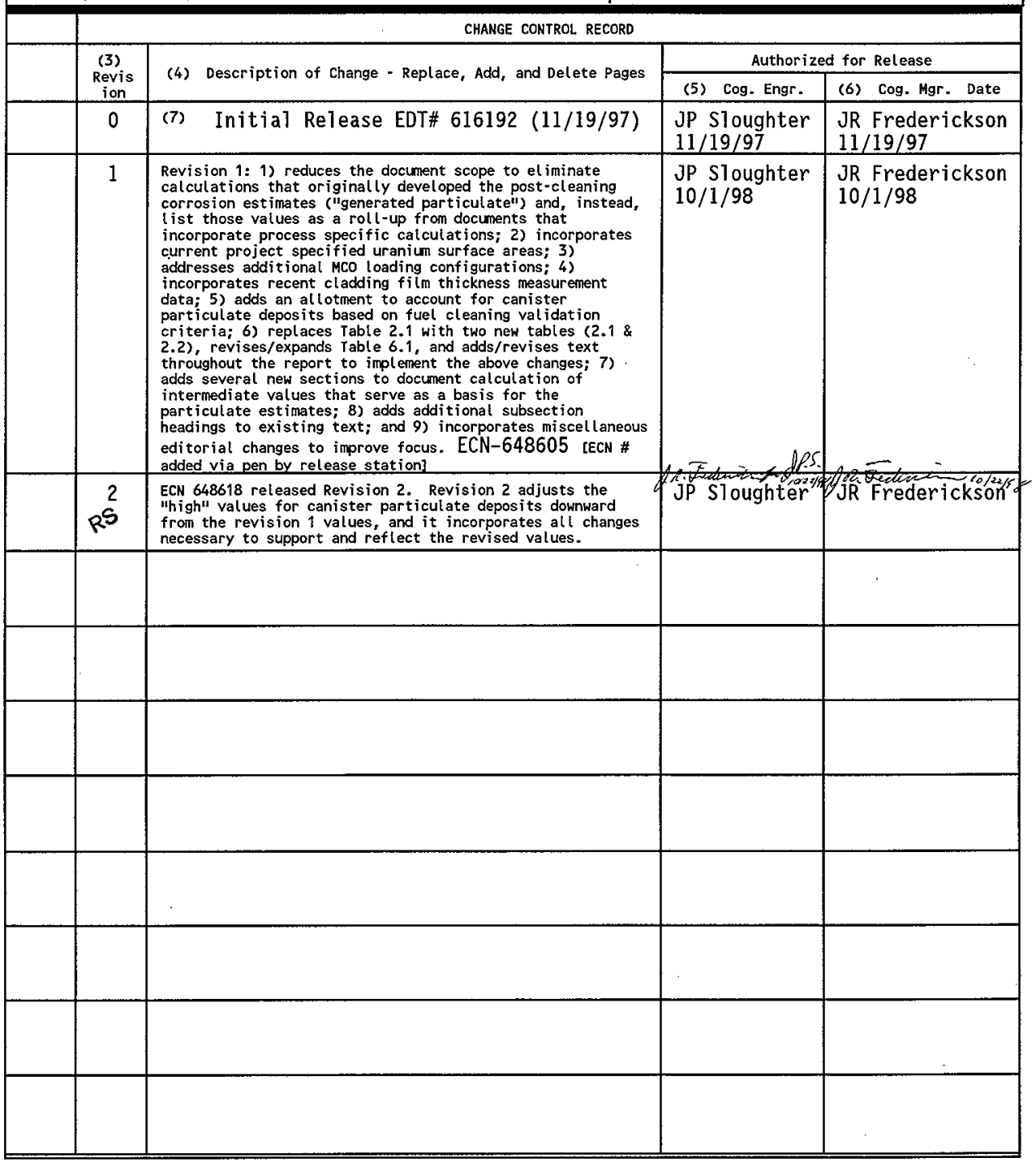


1.0 PURPOSE

1.1 SCOPE OF REVISION 1

2.0 SUMMARY

3.0 INTRODUCTION . . . . . . . . . . . . . . . . . . . . . 6

3.1 ANALYTICAL APPROACH .................. 6

4.0 SOURCES

4.1 PROCESS SUMMARY . . . . . . . . . . . . . 7

4.2 SPENT FUEL DESCRIPTION .................. 8

4.3 PARTICULATE LOCATIONS ................. 9

4.4 K BASIN FUEL SURVEY DATA . . . . . . . . . . . . . . 9

4.5 SURFACE EXAMINATIONS .................. 12

4.6 SUBSURFACE EXAMINATIONS ................. . . . 13

4.7 OTHER PARAMETERS ..................... 14

4.7.1 Cladding Surface Area . . . . . . . . . . . . . . 15

4.7.2 Uranium Surface Area . . . . . . . . . . . . . . 15

4.7.3 Particulate Density ............... 16

5.0 PARAMETERS, TECHNICAL BASES, AND ASSUMPTIONS . . . . . . . . . . . . 17

5.1 PARTICULATE LOCATIONS . . . . . . . . . . . . . . . . 17

5.2 PARAMETERS ....................... 17

5.2 .1 Surface Films ................. 18

5.2.1.1 Cladding Films .............. 19

5.2.1.2 Uranium Surface Films ............. 19

5.2.2 Adhering Particulates . . . . . . . . . . . 20

5.2.2.1 Scrap Basket .. . . . . . . . . . . . 20

5.2.2.2 Fuel Basket ................ 21

5.2 .3 Canister Particulate . . . . . . . . . . . . 22

5.2.3.1 Scrap Basket ............... 22

5.2.3.2 Fuel Basket ............... 22

5.2 .3 .2 .1 Minimum Sample Size to Achieve 99\%
Confidence . . . . . . . . 25

5.3 ASSUMPTIONS . . . . . . . . . . . . . . . . . . . . . . . . . . 26

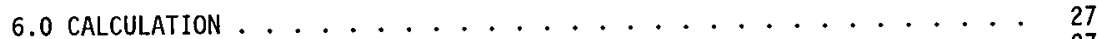

6.1 SCOPE OF CALCULATION . . . . . . . . . . . . . . . . . 27

6.2 MASS CALCULATION EQUATIONS ................. 27

6.3 RESULTING PARTICULATE MASS VALUES . . . . . . . . . . . . . 30

6.3.1 Case 1: Zero Scrap Baskets - Five Fuel Baskets . . . . 30

6.3.2 Case 2: One Scrap Basket - Four Fuel Baskets . . . . . 31

6.3.3 Case 3: Two Scrap Baskets - Three Fuel Baskets . . . . 32

6.5 REMARKS ON USE OF PARTICULATE INVENTORY VALUES . . . . . . . . . . . 35

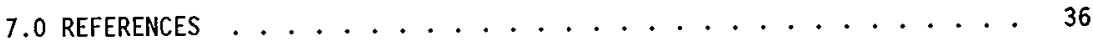

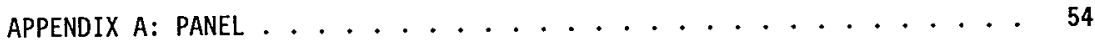

APPENDIX B: INDEPENDENT REVIEW ............... 57 
HNF-1527, Rev. 2

\section{FIGURES}

Figure $1 \quad$ N Reactor Mark IV Fuel Assembly

Figure 2 Example of an Intact Inner Fuel Element

Figure 3 Example of a Breached Outer Fuel Element

Figure 4 Example of a Defected Inner Fuel Element

Figure 5 Bad Fuel Assemblies in K East Basin

Figure $6 \quad$ A Bad $K$ West Outer Fue] Element

Figure $7 \quad$ Cloud Trailing an Extracted Outer Fuel Element

Figure $8 \quad$ Surface Coating Removed by Wire Brushing

Figure 9 Heavy White Coating Found on Some $K$ West Fuel Assemblies

Figure 10 Scraping Heavy White Coating from Surface of Element

Figure 11 Total Heavy White Coating Sample Recovered

Figure 12 Midsection and Bottom End Damage on K West Element $6743 \mathrm{U}$

Figure 13 Top and Bottom Damage on K East Element 5427E

Figure 14 Open Cracks at the Midsection and Bottom of $K$ West Element $7913 \mathrm{U}$

Figure 15 Center Damage Area on 6743U After Peeling and Sampling

Figure 16 Total Particulate Sample Recovered from Top Damage Area of $5427 \mathrm{E}$

\section{TABLES}

$\begin{array}{ll}\text { Table 4-1 } & \text { Spent Fuel Element Description } \\ \text { Table 4-2 } & \text { K Basin Fuel Survey Summary } \\ \text { Table 4-4 } & \text { Particulate Recovery Summary } \\ \text { Table 5-1 } & \text { Particulate Locations } \\ \text { Table 5-2 } & \text { Fixed Parameters } \\ \text { Table 6-1 } & \text { Summary of Derived Particulate Mass Values }\end{array}$


HNF-1527, Rev. 2

\section{ESTIMATES OF PARTICULATE MASS IN MULTI-CANISTER OVERPACKS}

\subsection{PURPOSE}

Reliable estimates of the quantities and types of particulate materials that may be within Multi-canister 0verpacks (MCO) are important to the Spent Nuclear Fuel (SNF) Project for several reasons. Estimates of SNF particulates are necessary in order to define worst case radioactive releases from MCOs for postulated accidents, while estimates of al1 particulates (both radioactive and non-radioactive) are necessary to define the amount of water that could potentially exist as hydrated chemical compounds within MCOs.

The primary purpose of this report is to: 1) develop and document a process for estimating the types and quantities of particulates that may remain on or within spent nuclear fuel and scrap after it has been cleaned at the $K$ Basins and loaded into stainless steel baskets for placement into MCOs; and 2) to provide those estimates. The goal of the estimating process is to: a) create defensible low, best estimate, and high values for post-cleaning residual particulate using the best available evidence; and b) to evaluate possible MCO payload configurations (i.e., fuel baskets versus scrap baskets) against these estimates and, thereby, identify bounding MCO configurations for the various types of particulate considered.

A secondary purpose of this document is to provide an overall roll-up of the particulate mass that may exist within nominal and bounding MCOs by 1 isting this document's results for post-cleaning residual particulate in tables (Table 2.1 and 2.2) that also include (by reference to other documents) results for particulate mass that accrues from post-cleaning fuel corrosion.

Note that the term "particulate", as used in this report, applies to thin surface films as well as to coarse particles and agglomerates. Films may be present on cladding and exposed fuel surfaces, whereas coarse particles and agg Tomerates are typically limited to fuel damage locations, either adhering to the exposed uranium or beneath the surface of the cladding at the damage locations. A small amount of deposited canister particulate may also remain within fuel assembiy flow channels after completion of the cleaning process. Also note that this report addresses both radioactive and non-radioactive particulates.

\subsection{SCOPE OF REVISION 1}

The scope of the Revision 1 document includes: 1) calculation of the quantities (and types) of residual particulate that may be on or within freshly cleaned fuel and scrap; and 2) provision of summary listings of the total particulate mass that may be within nominal and bounding particulate case MCOs at various points during their service life (Tables 2.1 and 2.2). Whereas Revision 0 included calculations for the particulate mass generated by post-cleaning corrosion ("Generated Particulate"), this revision obtains those estimates from two related documents (Sherre11 1998a/1998b). 


\subsection{SUMMARY}

High, best estimate, and low values are developed for particulate quantities (mass) and types (physical form and chemical make-up) within MCO baskets that have been loaded with freshly cleaned fuel assemblies and scrap. These per-basket estimates are then applied to all anticipated MCO payload configurations (Cases 1 through 3 of Table 6.1) to identify which configurations are bounding for each type of particulate.

The residual particulate material (i.e., particulate that may remain on and within freshly cleaned fuel) consists of films, which are found on the Zircaloy cladding and uranium surfaces, and particulate, which is found on and within the fuel assemblies and fragments.

The "high" values listed for cladding films under Case 1 of Table 6.1 are bounding for cladding films because the five fuel basket/zero scrap basket configuration of Case 1 contains the maximum possible cladding area. Case 1 al so represents the bounding "canister particulate" MCO because that particulate category is limited to materials that may lodge within fuel assembly flow channels, and because that case includes the largest number of intact fue $]$ assemblies (i.e., flow channels). The Case 3 configuration is bounding for total particulates because its two-scrap-basket/three-fuel-basket payload contains the maximum possible exposed uranium area. The "best estimate" values listed under Case 2 are, by definition, "nominal" because Case 2 represents a typical MCO payload configuration (one scrap basket and four fuel baskets).

Finally the resulting bounding and nominal values for residual particulates are combined with corresponding values for particulates that may be generated by corrosion of exposed uranium after the fuel has been cleaned (Sherrell $1998 \mathrm{a} / 1998 \mathrm{~b})$. The resulting rounded nominal estimate for a typical MCO after 40 years of storage is $8 \mathrm{~kg}$ (see Table 2.1). The estimate for a bounding total particulate case $M C O$ is that it may contain up to $64 \mathrm{~kg}$ of particulate after 40 years of storage (see Table 2.2). Note that the $18.8 \mathrm{~kg}$ of "adhering particulate" listed in Table 2.2 is intended to represent only materials that are very difficult to remove and, therefore, not readily available for release from an $\mathrm{MCO}$ (see the last paragraph of section 5.3 and the fifth paragraph of section 4.6$)$. The same consideration applies to the table's $1.1 \mathrm{~kg} 1$ isting for oxide films on uranium. 
Table 2.1: Particulate Content of a Nominal MCO (See Note 1)

\begin{tabular}{|c|c|c|c|}
\hline PARTICULATE TYPE & PARTICULATE SOURCE & EST IMATED PART ICULATE MASS & REFERENCE FOR ESTIMATE \\
\hline $\begin{array}{c}\text { Cladding surface Film } \\
\text { (See note 2) }\end{array}$ & Residual After Cleaning & $2.85 \mathrm{~kg}$ & Table 6.1 , Case 2 \\
\hline $\begin{array}{l}\text { oxide Films on } \\
\text { Exposed Uranium }\end{array}$ & Residuat After Cleaning & $0.06 \mathrm{~kg}$ & Table 6.1 , Case 2 \\
\hline Adhering Particulate & Residual After Cleaning & $2.42 \mathrm{~kg}$ & Table 6.1 , Case 2 \\
\hline $\begin{array}{c}\text { Canister Particulate } \\
\text { (See note 4) }\end{array}$ & Residual After Cleaning & $0.52 \mathrm{~kg}$ & Table 6.1 , Case 2 \\
\hline$\ldots-$ & Sub-Total & $5.85 \mathrm{~kg}$ & $-\infty$ \\
\hline Generated Particulate & $\begin{array}{c}\text { Corrosion by Basin Water } \\
\text { in Loadout Queue }\end{array}$ & $\begin{array}{c}0.052 \mathrm{~kg} \\
\text { (See note 3) } \\
\end{array}$ & $\begin{array}{l}\text { HNF-SD-W441-CN-001 } \\
\text { (Sherrell 1998a) }\end{array}$ \\
\hline Generated Particulate & $\begin{array}{l}\text { Corrosion by MCO Water } \\
\text { During Transfer to CVDF }\end{array}$ & $\begin{array}{c}0.003 \mathrm{~kg} \\
\text { (See note 3) }\end{array}$ & $\begin{array}{l}\text { HNF -SD-W441-CN-001 } \\
\text { (Sherrell 1998a) }\end{array}$ \\
\hline Generated Particulate & $\begin{array}{l}\text { Corrosion by MCO Water } \\
\text { During Connection, MCO } \\
\text { Heat-Up, and MCO Draining }\end{array}$ & $\begin{array}{c}0.020 \mathrm{~kg} \\
\text { (See note } 3 \text { ) }\end{array}$ & $\begin{array}{l}\text { HNF-SO-W441-CN-001 } \\
\text { (Sherrell 1998a) }\end{array}$ \\
\hline--------------- & Sub-Total & $0.075 \mathrm{~kg}$ & $---------\cdots----$ \\
\hline Generated Particulate & $\begin{array}{c}\text { Corrosion by Water Vapor } \\
\text { During Post-Drain Cvo } \\
\text { Operations }\end{array}$ & $0.309 \mathrm{~kg}$ & $\begin{array}{c}\text { HNF-3048 } \\
\text { (Sherrell 1998b) }\end{array}$ \\
\hline Generated Particulate & $\begin{array}{l}\text { Corrosion by Water Vapor } \\
\text { During Transport to CSB }\end{array}$ & $0.229 \mathrm{~kg}$ & $\begin{array}{c}\text { HNF-3048 } \\
\text { (Sherrell 1998b) } \\
\end{array}$ \\
\hline Generated Particulate & $\begin{array}{l}\text { Corrosion by Water Vapor } \\
\text { During Storage at CSB }\end{array}$ & $1.544 \mathrm{~kg}$ & $\begin{array}{c}\text { HNF-3048 } \\
\text { (Sherrell 1998b) } \\
\end{array}$ \\
\hline 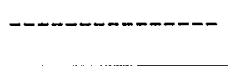 & $\begin{array}{l}\text { TOTAL NOMINAL } \\
\text { PARTICULATE MASS }\end{array}$ & $\begin{array}{l}8.0 \mathrm{~kg} \\
(\text { See note } 1)\end{array}$ & $---n--m$ \\
\hline
\end{tabular}

\section{Notes:}

1) Alt estimates in this table are based on the MCO configuration used for Case 2 of Table 6.1 (1 scrap basket and 4 fuel baskets) because that configuration will be typical of most MCOs.

2) This nominal value is based on the observation that about $25 \%$ of the assemblies are coated with aluminum hydroxide and that the remaining assemblies are only coated with uranium oxides. The cladding $\mathrm{f} i \mathrm{~lm}$ total represents $2.52 \mathrm{~kg}(0.39+2.13)$ of Aluminum Hydroxide $+0.33 \mathrm{~kg}(0.05+0.28)$ of Uranium Oxide(s) $=2.85 \mathrm{~kg}$ total. See section 5.2 and the "best estimate" values listed under Case 2 of Table 6.1 .

3) Estimates for the particulate mass generated from corrosion of exposed uranium surfaces by water within the basin or MCO are based on results listed [by Table 2-1 of HNF-SD-W441-CN-001] for the mass of uranium metal corroded. The particulate estimates in this table are based on adjusting the uranium metal values by a factor of $270 / 238$ to reflect the difference between the atomic weight of uranitum and the molecular weight of the assumed particulate form $\left(\mathrm{UO}_{2}\right)$.

4) The "canister particulate" category refers to agglomerated canister particulate that remains lodged within fuel assembly flow channels after completion of the fuel cleaning process. 
HNF-1527, Rev. 2

Table 2.2: Particulate Content of a Bounding MCO (See Note 1)

\begin{tabular}{|c|c|c|c|}
\hline PARTICULATE TYPE & PARTICULATE SOURCE & ESTIMATED PARTICULATE MASS & REFERENCE FOR ESTIMATE \\
\hline $\begin{array}{c}\text { Cladding surface Film } \\
\text { (See note } 2)\end{array}$ & Residual After cleaning & $9.5 \mathrm{~kg}$ & $\begin{array}{c}\text { Table } 6.1 \text {, Case } 3 \\
\text { (See note } 3 \text { ) }\end{array}$ \\
\hline $\begin{array}{l}\text { Oxide Films on } \\
\text { Exposed Uranium }\end{array}$ & Residual After Cleaning & $1.1 \mathrm{~kg}$ & Table 6.1 , Case 3 \\
\hline Adhering Particulate & Residual After Cleaning & $18.8 \mathrm{~kg}$ & Table 6.3 , Case 3 \\
\hline $\begin{array}{c}\text { Canister Particulate } \\
\text { (See Note 7) }\end{array}$ & Residual After cleaning & $1.0 \mathrm{~kg}$ & $\begin{array}{c}\text { Table } 6.1 \text {, Case } 3 \\
\text { (See note 4) }\end{array}$ \\
\hline ---------- & Sub-Tota] & $30 \mathrm{~kg}$ & 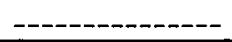 \\
\hline Generated Particulate & $\begin{array}{c}\text { Corrosion by Bas in Water } \\
\text { in Loadout Queue }\end{array}$ & $\begin{array}{c}7.5 \mathrm{~kg} \\
\text { (See note 5) }\end{array}$ & $\begin{array}{c}\text { HNF-SD-W441-CN-001 } \\
\text { (Sherrell 1998a) }\end{array}$ \\
\hline Generated Particulate & $\begin{array}{l}\text { Corrosion by MCO Water } \\
\text { During Transfer to CVDF }\end{array}$ & $\begin{array}{c}1.7 \mathrm{~kg} \\
\text { (See note 5) }\end{array}$ & $\begin{array}{c}\text { HNF-SD-W441-CN-001 } \\
\text { (Sherrell 1998a) }\end{array}$ \\
\hline Generated Particulate & $\begin{array}{l}\text { Corrosion by MCO Water } \\
\text { During Connection, MCO } \\
\text { Heat-Up, and MCO Draining }\end{array}$ & $\begin{array}{c}0.9 \mathrm{~kg} \\
\text { (See note 5) }\end{array}$ & $\begin{array}{l}\text { HNF-SD-W441-CN-001 } \\
\text { (Sherretl 1998a) }\end{array}$ \\
\hline Generated Particulate & $\begin{array}{l}\text { Pre-Drain Corrosion } \\
\text { Contingency }\end{array}$ & $\begin{array}{c}4.9 \mathrm{~kg} \\
\text { (see note 5) }\end{array}$ & $\begin{array}{c}\text { HNF-SD-W441-CN-001 } \\
\text { (Sherrel ( 1998a) }\end{array}$ \\
\hline --ーーー-ー-ー-ー-ー-ー & Sub-Tota] & $15 \mathrm{~kg}$ & -------------- \\
\hline Generated Particulate & $\begin{array}{c}\text { Corrosion by Water Vapor } \\
\text { During Post-Drain CVD } \\
\text { Operations }\end{array}$ & $6.5 \mathrm{~kg}$ & $\begin{array}{c}\text { HNF-3048 } \\
\text { (Sherrell 1998b) }\end{array}$ \\
\hline Generated Particulate & $\begin{array}{l}\text { Post-Orain corrosion } \\
\text { Contingency for cVDF }\end{array}$ & $3.3 \mathrm{~kg}$ & $\begin{array}{c}\text { HNF-3048 } \\
\text { (Sherrell 1998b) }\end{array}$ \\
\hline 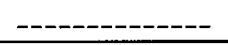 & Sub-Total & $9.8 \mathrm{~kg}$ & ------------u- \\
\hline Generated Particulate & $\begin{array}{l}\text { Corrosion by Water Vapor } \\
\text { During Transport to CSB }\end{array}$ & $\begin{array}{c}1.5 \mathrm{~kg} \\
\text { (see note } 6 \text { ) }\end{array}$ & $\begin{array}{c}\text { HNF-3048 } \\
\text { (Sherretl 1998b) }\end{array}$ \\
\hline Generated Particulate & $\begin{array}{c}\text { Corrosion by Water Vapor } \\
\text { During Storage at CSB }\end{array}$ & $\begin{array}{c}7.3 \mathrm{~kg} \\
\text { (See note 6) }\end{array}$ & $\begin{array}{c}\text { HNF-3048 } \\
\text { (Sherrell 1998b) }\end{array}$ \\
\hline$-m-n-m-n$ & $\begin{array}{l}\text { TOTAL BOUNDING } \\
\text { PARTICULATE MASS }\end{array}$ & $\begin{array}{c}64 \mathrm{~kg} \\
(\text { see note } 1)\end{array}$ & ------ \\
\hline
\end{tabular}

\section{Notes:}

1) All estimates in this table are based on the MCo configuration used for Case 3 of Table 6.1 (2 scrap baskets and 3 fuel baskets), which represents a bounding total particulate inventory $\mathrm{MCO}$.

2) While most fuel cladding films will contain no aluminun hydroxide at all, the bounding value for cladding surface films is based on pure aluminum hydroxide. See section 5.2.

3) No more than $9.5 \mathrm{~kg}$ of cladding film can be loaded into a bounding total particulate inventory MCO (i.e., an MCO with 2 scrap baskets \& 3 fuel baskets). However, the actual bounding estimate (10.7 kg) is listed under Case 1 ( 5 fuel baskets) of Table 6.1 because that case includes the most cladding.

4) While no more than $1.0 \mathrm{~kg}$ of canister particulate can be loaded into a bounding total particulate inventory $\mathrm{MCO}$, the actual bounding estimate for canister particulate $(1.6 \mathrm{~kg})$, which is entirely attributed to materials that may ladge within fuel assembly flow channels, is listed under Case 1 ( 5 fuel baskets) of Table 6.1 because that case includes the largest number of fuel assembt ies.

5) Estinates for the particulate mass generated from corrosion of exposed uraniun surfaces by water within the basin or MCO are based on results listed [by Table 2-2 of HAF-SD-W441-CN-001] for the mass of uranium metal corroded. The corresponding particulate estimates in this table are based on adjusting the uranium metal values by a factor of $270 / 238$ to reflect the difference between the atomic weight of uranium and the molecular weight of the assuned particulate form $\left(\mathrm{UO}_{2}\right)$.

6) No contingency was deemed necessary for transport to the CSB, nor for storage at the CSB, because those calculations were based on bounding assumptions and/or input data.

7) See Note 4 of Table 2.1. 
Due to the inherent variability in the geometry of fuel (damage level, character of scrap, character of particulate, etc.) and the Timited amount of characterization data presently and economically available, it is not possible to develop an estimate that is based entirely on a quantitative, statistical analysis. The estimate is, instead, based on the collective judgement of an expert panel in light of a mix of extensive visual surveys, limited characterization data, and existing project evaluations. In providing this estimate, the panel strived to document a clear traceable path from available evidence to the bottom-1ine results. The panel was composed of persons with diverse backgrounds but familiarity with K-basins fuel and the issues associated with particulate loading. Participants were: Thierry Flament (Numatec Hanford Corporation), Lewis Muhlestein (ARES), Al Pitner (Duke Engineering \& Services Hanford), Marty Plys (Fauske \& Associates), and Jim Sloughter (Numatec Hanford Corporation). A brief statement of qualifications appears in Appendix A.

Basic steps in the process were to gather and review available evidence, identify and mathematically describe locations holding particulate, formulate appropriate technical bases and assumptions, 1ist the required parameters, and provide parameter values supported by the evidence. Evidence used includes videotapes and photographs of fue 1 assemblies and particulate, survey data on the damage state of $\mathrm{K}$ Basins fuel, and characterization data. Simple geometric relations were developed for the identified particulate locations. Reasons for selection of each parameter value are documented here. 
HNF-1527, Rev. 2

\subsection{INTRODUCTION}

The material loaded into an MCO that could potentially be released from an MCO or contain compounds that may contain hydrated water can be present as: 1) films on the materials in an $\mathrm{MCO}$; and 2) particulate adhering to, or trapped within the fuel segments and assemblies.

The residual film and particulate estimates developed by this document are calculated as a mass per MCO. The calculations involve relatively simple equations that rely on physical and process design values, existing project technical baseline evaluations, and available characterization data. Section 3.1 provides an outline of the analytical approach and the information used in the calculations. Equations and calculational details are presented in section 6 .

\subsection{ANALYTICAL APPROACH}

The quantity of material from films on the cladding and uranium surfaces is calculated by multiplying an appropriate area by the weight of the film per unit area. Cladding surface film areas are calculated from fuel assembly dimensions. The number of equivalent assemblies is derived from the design number of assemblies placed in fuel baskets in an MCO and the equivalent number of assemblies that can be placed in a scrap basket. Uranium surface areas are from existing project technical baseline documents.

Direct mass per unit area data were obtained on cladding films by removing films from known areas on cladding samples retrieved from $K$ West Basin and then weighing the recovered materials. Indirect cladding film data were obtained by measuring the film thickness on fuel assemblies within the basin and then using literature values for compound densities to convert the thickness data to mass per unit area. The mass per unit area data for films on uranium surfaces were obtained by multiplying laboratory film thickness measurements by literature values for the densities of uranium compounds.

The quantity of particulate that may adhere to, or be trapped within, fuel assemblies and scrap segments is calculated by multiplying weights of particulate removed from fuel assemblies by the equivalent fuel assembly count of an MCO.

The calculation for the quantity of particulate deposited within fuel flow channels (i.e., "canister particulate") is based on fuel cleaning process validation criteria.

This report is organized to provide: 1) an overall summary (in section 2) of the estimated particulate burdens for bounding and nominal MCOs, including estimates from other documents that address particulate from post-cleaning fuel corrosion; 2) a summary (in Section 4) of the information sources used by this document to develop the residual particulate estimates; 3 ) data summaries and assumptions (in Section 5) that were input to the residual particulate calculations; and 4) the equations, calculations, and results (in section 6) for the post-cleaning residual particulate estimate that it develops. 
HNF-1527, Rev. 2

\subsection{SOURCES}

This section provides the information sources used to formulate technical bases, create assumptions, and assign values to process and geometric parameters.

\subsection{PROCESS SUMMARY}

Spent fuel is retrieved, cleaned, loaded into stainless steel baskets, placed into MCOs, and transferred to the Cold Vacuum Drying Facility (CVDF) using a truck transport system. After completion of draining and drying operations at the CVDF, the MCO is transported to the Canister Storage Building (CSB).

Fuel retrieval systems, installed underwater in each basin, transfer fuel from the current basin storage canisters into stainless steel baskets that are sujtable for loading into MCOs. Fuel materials are separated from particulates and debris during the fuel retrieval process. Particulate removal is accomplished by inserting the fuel canisters into a fuel washing machine; the machine provides both mechanical agitation and flushing by slowly tumbling the fuel canisters past high pressure water jets. This is performed within a confinement enclosure to minimize the impact of fuel washing on basin water quality.

After washing, the fuel is dumped onto a table for fuel segregation. A remote manipulator system is used to handle material on the dump table. Non-fuel material is separated and transferred to the debris handling system. The remaining cleaned fuel is loaded into stainless steel baskets and staged within a loadout queue near the basin's loadout pit.

Two types of baskets are available for the cleaned fuel, depending on the fuel condition after cleaning: a fuel basket for generally intact fuel assemblies, and a scrap basket for fuel fragments and pieces. Separate fuel and scrap baskets have been designed for Mark $1 \mathrm{~A}$ and Mark IV fuel to address criticality controls for the different fuel enrichments. Fuel and scrap baskets are removed from each basin by loading the baskets into an MCO/Cask assembly that is designed for transport by a tractor-trailer system. 


\subsection{SPENT FUEL DESCRIPTION}

Spent fuel consists of the irradiated fuel elements currently stored within canisters in the $K$ East and $K$ West basins. Each canister provides storage for up to fourteen fuel elements. Regardless of type, each fuel element has a concentric tube-in-tube configuration (Figure 1). Diameter, 1ength and fue 1 enrichment vary between the fuel types. Each uranium metal tube is clad with Zircaloy-2. Table 4.1 provides a summary of the variation in the basic characteristics of N Reactor fuel (Praga 1998).

Table 4.1: Spent Fuel Element Description

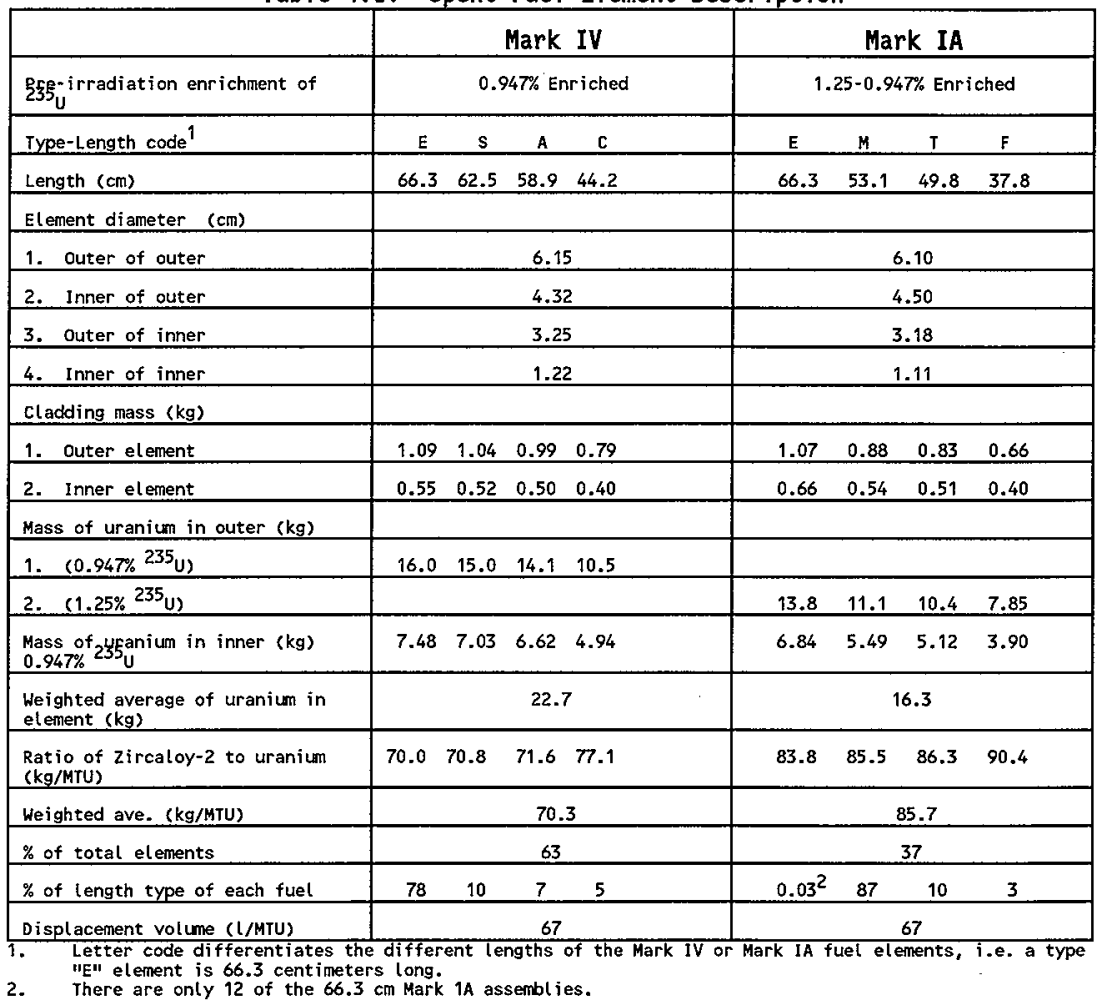

Gross Weight of Type E Mark IV Assembly

From above: Cladding $=1.09 \mathrm{~kg}$ (Outer) $+0.55 \mathrm{~kg}$ (Inner) $=1.64 \mathrm{~kg}$

Fuel $=16.0 \mathrm{~kg}$ (Outer) $+7.48 \mathrm{~kg}$ (Inner) $=\underline{23.48 \mathrm{~kg}}$

TOTAL WEIGHT $25.12 \mathrm{~kg}$ 
HNF-1527, Rev. 2

\subsection{PARTICULATE LOCATIONS}

Particulate locations are defined based on avajlable characterization data (Jensen 1998; Marschman 1997a and 1997b), visual examinations (Pitner 1995, 1996, 1997a, 1997b, 1997c, 1998), and fuel geometry (Praga 1998). Particulate locations considered for this analysis are in two categories: 1) films or coatings; and, 2) particulate material existing on and within the fuel assemblies.

Films have been observed and measured on the Zircaloy cladding and on exposed uranium surfaces. This report further categorizes the film locations into the films present in the scrap baskets and the fuel baskets. Thus there are four film locations:

- Zircaloy cladding surface film - scrap basket

- Zircaloy cladding surface film - fuel basket

- Uranium surface film - scrap basket

- Uranium surface film - fuel basket

Adhering particulate has been observed and measured on and within the fuel elements and fragments. In addition to the adhering particulate, some fuel canisters also contain significant quantities of settled particulate (herein termed "canister particulate"). Fuel handling and washing operations are designed to separate the canister particulate from fuel elements and fragments, including any accumulations within the fuel assembly flow channels. Such an accumulation has only been observed within flow channels once, and that was easily dislodged. Although flow channel deposits are not expected to remain within the assemblies after cleaning, validation testing can only verify that a certain percentage of the assemblies will be free of canister particulate deposits. Based on a trade-off that is outlined in section 5.2.3.1, it can be assumed that the pieces and fragments of fuel in the scrap baskets do not contain deposits of canister particulate (even though they may contain some). Thus there are three particulate locations:

- Adhering/trapped particulate - scrap basket

- Adhering/trapped particulate - fuel basket

- Canister particulate deposits - fuel basket

\subsection{K BASIN FUEL SURVEY DATA}

A full basin video survey of fuel stored in K East Basin was conducted in 1994 (Pitner 1995). The fuel in this basin is stored in open canisters with the tops of the fuel elements visible in most of the canisters (some were covered with debris). The condition of each of the fuel assemblies visually examined was rated, based on the top end views. The video survey was subsequently followed up by limited "lift and look" surveys where about 225 individual assemblies were extracted from selected canisters and examined over their full length (Pitner 1997a). These extended examinations basically confirmed the results for fuel damage distributions established from the previous "top only" visual survey. 
In $K$ West Basin, the fuel is stored within sealed canisters. Valves and vent isolation traps are incorporated into the canister lids to permit the addition of corrosion inhibitor (potassium nitrite) and cover gas (nitrogen), and to allow excess gas to escape while isolating the canister water from the basin water. A limited "lift and look" survey was conducted in K West Basin where lids were removed from some twenty selected canisters and about 250 fuel assemblies were extracted and examined (Pitner 1997b).

The original visual fuel survey in K East Basin (Pitner 1995) rated fuel based on how well it could be handled, which was the characteristic of interest at that time. Subsequent developments led to the current fuel disposition strategy, which entails cleaning the fuel and loading it into MCOs. An additional assessment of observations from the original visual survey was accordingly conducted to evaluate the condition of each fuel assembly with respect to the relative need for cleaning (Pitner 1996). The results of the $K$ West "lift and look" campaign were also subsequently evaluated on this. same basis. Fuel conditions in these assessments were rated based on the following four categories (Pitner 1998).

Intact No evidence of cladding breach or deposited particulate. Figure 2 is an example of an intact inner element from $K$ East Basin. The element is being held by a grapple used to extract it from the canister. A "W-spring" and spacer shoe used to center the inner element inside the outer element are visible in the photo.

Breached Minor cladding rupture with no reacted fuel or deposited particulate visibly present. Figure 3 is an example of a breached outer fuel element from $K$ West Basin. A top end rupture and a minor spiral crack can be seen. A portion of the top of the element evidently protruded into the cover gas above the water in the canister, and does not exhibit the grayish coating seen on the lower portion.

Defected Definite evidence of cladding breach with reacted fuel egressing from the element. The amount of exposed fuel may be significant, but there is no gross cladding spljtting, element dilation, or fuel voiding. In Figure 4, the top end of an inner element from $K$ East Basin is seen to be ruptured, with reacted fuel present in the area of the rupture.

Bad Gross failure is evident with substantial element dilation, cladding splitting, fuel "mushrooming," or fuel voiding. Figure 5 shows a canister in $K$ East Basin that contains fuel assemblies that would all be rated in the "Bad" category. Considerable cladding splitting and fuel voiding are prevalent in this canister.

The resulting damage distributions for fuel elements in the two basins are given in Table 4.2 (Reilly 1998). Fuel elements in the "Bad" category can be considered scrap basket candidates, while it should be possible to load most of the remaining elements into fuel baskets. 
HNF-1527, Rev. 2

Table 4.2: K Basin Fuel Survey Summary

\begin{tabular}{||c||c|c|c|c||}
\hline \multirow{2}{*}{$\begin{array}{l}\text { Fue1 } \\
\text { Condition } \\
\text { Category }\end{array}$} & \multicolumn{2}{|c|}{ K East } & \multicolumn{2}{c||}{ K West } \\
\cline { 2 - 5 } & Inners & Outers & Inners & 0uters \\
\hline Intact & $86 \%$ & $49 \%$ & $84 \%$ & $50 \%$ \\
\hline Breached & $9 \%$ & $9 \%$ & $14 \%$ & $39 \%$ \\
\hline Defected & $4 \%$ & $38 \%$ & $0 \%$ & $0 \%$ \\
\hline Bad & $1 \%$ & $4 \%$ & $2 \%$ & $11 \%$ \\
\hline
\end{tabular}

The majority of the damage occurs in the outer elements, which is to be expected based on their greater vulnerability during discharge and handling operations. About $85 \%$ of the inner elements and about half of the outer elements in both basins were found to be intact. It is seen that no $K$ West fuel elements fall into the defected category. This presumably reflects the effectiveness of the corrosion inhibitor added to the canisters. While the percentage of bad outer elements in $K$ West appears to be significantly greater than that in $K$ East, the actual degree of damage on bad $K$ West elements is generally less than that seen on bad K East elements. Figure 6 shows a $K$ West element that has split cladding on the top end, and would accordingly be classified as bad. However, the overall damage level on this element is significantly less than on any of those shown in Figure 6 for bad elements at. K East Basin.

When fuel elements were extracted from the canisters for examination within the basin or transfer to a shipping cask for subsequent characterization activities, clouds of flocculent particulate often trailed the element, particulariy in the $K$ East Basin. This is canister particulate that is drawn from the bottom of the canister. by the lifting action on the element. Figure 7 shows an intense cloud trailing a $K$ East outer element being transferred from the canister to a shipping container. The clouds were very flocculent in nature, but generally settled relatively quickly.

Most of the fuel elements in the $K$ Basins had a thin grayish colored coating on their surface. One barrel of one canister examined in $K$ West Basin contained fuel elements with reddish or bright orange film on them. It was found that these light coatings were easily removed by a wire brush apparatus. Figure 8 shows an outer element after wire brushing the portion below the top spacers shoes. As shown, the lower brushed portion appears clean, while the grey film can still be seen on the upper portion. The rust blisters on the carbon steel spacer shoes were also readily removed by wire brushing.

Some of the fuel elements in the sealed $K$ West canisters were found to have a heavy white or translucent coating on them. This coating is illustrated in Figure 9, which shows the coating present on both the inner and outer elements of the fuel assembly. It was noted that the coating sometimes flaked off the surface of the element when struck by another object. About $15 \%$ (3 of 20) of the canisters opened in $K$ West were found to have this heavy coating on the fuel assemblies, and always in both barrels of the canister. Alt of the fuel assemblies displaying this heavy white coating were contained in three

aluminum canisters. The assemblies in a fourth aluminum canister had a lesser degree of this type of coating. 
HNF-1527, Rev. 2

\subsection{SURFACE EXAMINATIONS}

Cladding Films - Surface films on Zircaloy cladding and uranium surfaces have been examined in the laboratory. Based on visual examinations at $K$ East Basin, eleven fuel elements were selected for characterization. All elements were observed to have a grey film coating the cladding surface. Two outer elements were selected for characterization of the grey film. The entire outer surfaces of the outer elements were scraped and brushed with Scotchbrite. The film was easily removed, and approximately $200 \mathrm{mg}$ of material was recovered from each element. The quantity of material per unit area was conservatively estimated at $0.55 \mathrm{mg} / \mathrm{cm}^{2}$ (Marschman, 1997a). This value was calculated by multiplying the amount of recovered material by a factor of 3 to account for material losses, removal efficiencies, and retention on the Scotchbrite, and then dividing by the outer surface area of the elements. The material has been analyzed by $x$-ray diffraction to contain several uranium compounds including $\mathrm{UO}_{4}, 4 \mathrm{H}_{2} \mathrm{O}, \mathrm{UO}_{4} .2 \mathrm{H}_{2} \mathrm{O}, \mathrm{UO}_{3}, \mathrm{U}_{3} \mathrm{O}_{7}, \mathrm{U}_{4} \mathrm{O}_{9}, \mathrm{UO}_{2}, \mathrm{U}_{3} \mathrm{O}_{8}$ and $\mathrm{UO}_{3} .1 .5 \mathrm{H}_{2} \mathrm{O}$ (Marschman 1997a).

The KW canister cladding coatings appear somewhat different than the KE canister coatings (Sloughter 1998). Four samples were analyzed by X-ray diffraction and elemental analysis. Only one sample had high uranium content. The other three coatings were primarily iron and aluminum compounds. The coating sample observed to be reddish or bright orange was primarily composed of iron compounds.

A white film was observed on several assemblies from closed aluminum canisters in $K$ West Basin. The material was present on all assemblies in the four aluminum canisters observed. The coating was particularly heavy on assemblies from three of the canisters. The material was present on the outer surface of both outer and inner elements. Visual examination indicated that the material is also present on the inner surfaces of both outer and inner elements.

One $\mathrm{K}$ West element that was visually judged to represent elements with the largest amount of coating was selected and transferred to the hot cells for recovery of the heavy white coating from the fuel element. Figure 10 shows a putty knife being used to remove the coating from the surface of the element. Based on visual examinations, this technique was successful in removing all of the material, which typically spalled off as large flakes after air drying in the hot cel1. Figure 11 shows the total sample recovered after scraping the full outer surface of the element. The weight of this sample was $8.5 \mathrm{~g}$, which transiates into $8.3 \mathrm{mg} / \mathrm{cm}^{2}$. This material was determined to be approximately 90 percent aluminum hydroxide by a combination of $X$-Ray Diffraction and Inductively Coupled Plasma (ICP) techniques (Sloughter 1998).

The high levels of aluminum hydroxide on the fuel assemblies in the KW Basin aluminum canisters have been evaluated further. The coating thickness was determined by eddy current techniques on 40 fuel elements from 20 randomly selected aluminum canisters. Statistical analysis of the thickness data show that the mean weight of aluminum hydroxide per assembly is $10.6 \mathrm{mg} / \mathrm{cm}^{2}$, with a 99 percent confidence upper bound of $12.5 \mathrm{mg} / \mathrm{cm}^{2}$ (Jensen 1998).

FueT Uranium Oxide Films - Seven specimens from a Mark IV-E outer fuel element were examined using an optical metallograph (Marschman 1997b). Included were four specimens that had been subjected to conditioning tests simulating process conditions, and three that were in the as-received, as-cut condition. 
One of the as-received specimens had been cut from the damaged (or breached) end of the element. All other specimens were cut from the undamaged midregion of the fuel element.

The specimens were microscopically examined to 1) identify uranium hydride inclusions present in the uranium metal fuel, 2) measure the thickness of the oxide layer formed on the uranium edges and assess the apparent integrity and adhesion of the oxide layer, and 3) look for features in the microstructure that might provide an insight into the various corrosion processes that occurred during underwater storage in the $K$ West Basin. Observed metallographic features of the conditioned specimens were compared with those of the as-received specimens.

Short segments of a very thin uranium oxide layer were observed atong the fuel edges of most specimens. The layer appeared to be porous and was obviously non-adherent. Typically, the layer appeared to be in the process of pulling away from the fuel and flaking off. In all but one case, the maximum thickness of the layer was $3 \mu \mathrm{m}$. The one exception was a very short segment that was about $10 \mu \mathrm{m}$ thick, which was observed on a conditioned specimen.

\subsection{SUBSURFACE EXAMINATIONS}

Two outer fuel elements from $K$ West Basin and one outer element from $K$ East Basin were transferred to a hot cell to examine the fuel condition underneath damaged cladding areas (Pitner 1997c). The elements were selected based on the apparent "peelability" of the damaged cladding and the potential for corroded fuel beneath the damaged area.

The in-basin appearance of $\mathrm{K}$ West Element $6743 \mathrm{U}$ is shown in Figure 12 . The fuel element had open cracks near its midsection and split open cladding, with some fuel voiding at the bottom. Significant particulate trails out the bottom were noted when the fuel element was extracted from its canister for visual examination, and again, when it was extracted for transfer to the Single Fuel Element Canister (SFEC) for shipment to the hot cells. No particulate was seen to exit from the midsection breach during the in-basin handling.

The in-basin appearance of $\mathrm{K}$ East Element $5427 \mathrm{E}$ is shown in Figure 13 . The inner element was found to be stuck under the displaced end cap of the outer e] ement, so the full assembly was transferred to the SFEC. There was major damage apparent on both ends of the outer fuel element. Substantial particulate trailed from the assembly when it was removed from the canister, and particulate material was also released from the top end during the transfer operation. The outer element was subsequently broken in two near its cracked midsection when a flaring tool was used in the hot cell to open up the top end so that a grapple could be inserted.

The in-basin appearance of $\mathrm{K}$ West Element $7913 \mathrm{U}$ is shown in Figure 14 . The element had an open crack near its midsection, and also at the bottom. The fuel element actually had a hinged appearance at the midsection breach, and appeared ready to break in two. Considerable particulate was released when the element was extracted from its canister. At the visual examination station in the basin, particulate was observed to be continuously suctioned from the bottom breach area by a nearby pump used to capture loose debris in the pit. When the fuel element was extracted a second time for transfer to 
the SFEC, an overhead camera showed that particulate was periodically expelled from the midsection breach area as the element flexed during the extraction and transfer operation.

The loose cladding around damaged areas was peeled away and the underlying surface examined. Figure 15 shows the center breach area on the 67430 element after peeling and particulate sampling. As much of the particulate matter under the peeled region was collected as possible, using a combination of picks, scrapers, and brushes. However, it was found that, for the most part, the fuel under the peeled cladding was quite firm and it was difficult to remove particulate material. The largest amount obtained from any damage area (top of $5427 \mathrm{E}$ ) was $15.5 \mathrm{~g}$, shown in Figure 16.

The water from each SFEC was strained to capture any residue material that might have escaped from the fuel elements during shipping and handling. Typically, the quantity of material recovered from the SFEC was equal to or greater than that which could be scraped from damaged areas on the fue 1 elements after peeling away the cladding. This suggests that the cleaning procedure planned for the fuel elements prior to MCO loading should be quite effective in removing particulate material.

The total particulate material quantities recovered from all damaged areas on the fuel elements are given in Table 4.3 (Pitner 1997C).

Table 4.3: Particulate Recovery Summary

\begin{tabular}{|c|c|}
\hline Element & Total Recovered (g) \\
\hline KW 6743U & 6.1 \\
\hline KE 5427E & 20.3 \\
\hline KW 7913U & 11.9 \\
\hline
\end{tabular}

\subsection{OTHER PARAMETERS}

Cladding surface area, uranium surface area, and particulate density are all important parameters for this analysis. 
HNF-1527, Rev. 2

\subsubsection{Cladding Surface Area}

\section{Cladding Area of One Intact Fuel Assembly}

The cladding surface area of intact fuel is calculated from the dimensions given in Table 4.1 for a maximum length Mark IV assembly. The surface area of a maximum length Mark IA assembly is a few $\mathrm{cm}^{2}$ Tess. Although the resulting surface area represents the maximum area for all the types and lengths of elements in the $K$ Basins, it is conservatively input to all the cladding film calculations (i.e., low and best estimate, as well as high). From Table 4.1: Maximum Length $=66.3 \mathrm{~cm} ; 0$. . of Outer $=6.15 \mathrm{~cm} ; 1 . D$. of Outer $=4.32 \mathrm{~cm}$; $0 . D$. of Inner $=3.25 \mathrm{~cm}$; I.D. of Inner $=1.22 \mathrm{~cm}$.

$$
\begin{array}{lr}
\text { Area of Outer's O.D. }=66.3 \mathrm{~cm} *(\pi * 6.15 \mathrm{~cm})= & 1281.0 \mathrm{~cm}^{2} \\
\text { Area of Outer's I.D. }=66.3 \mathrm{~cm} *(\pi * 4.32 \mathrm{~cm})= & 899.8 \mathrm{~cm}^{2} \\
\text { Area of Outer's End }=2 *\left[\left(\pi^{*} \mathrm{R}^{2}\right)_{\mathrm{OD}}-\left(\pi^{*} \mathrm{R}^{2}\right)_{\mathrm{ID}}\right]= & \\
\qquad 2^{*}\left[\pi^{*}(6.15 \mathrm{~cm} / 2)^{2}-\pi^{*}(4.32 \mathrm{~cm} / 2)^{2}\right]=2 *\left[29.7 \mathrm{~cm}^{2}-14.7 \mathrm{~cm}^{2}\right]= & 30.0 \mathrm{~cm}^{2} \\
\text { Area of Inner's O.D. }=66.3 \mathrm{~cm} *(\pi * 3.25 \mathrm{~cm})= & 676.9 \mathrm{~cm}^{2} \\
\text { Area of Inner's I.D. }=66.3 \mathrm{~cm} *(\pi * 1.22 \mathrm{~cm})= & 254.1 \mathrm{~cm}^{2} \\
\text { Area of Inner's End }=\left(\pi^{*} \mathrm{R}^{2}\right)_{\mathrm{OD}}-\left(\pi^{*} \mathrm{R}^{2}\right)_{\mathrm{ID}}= & \\
\qquad 2^{*}\left[\pi^{*}(3.25 \mathrm{~cm} / 2)^{2}-\pi^{*}(1.22 \mathrm{~cm} / 2)^{2}\right]=2^{*}\left[8.3 \mathrm{~cm}^{2}-1.2 \mathrm{~cm}^{2}\right]=14.2 \mathrm{~cm}^{2}
\end{array}
$$

TOTAL CLADDING AREA OF ONE INTACT FUEL ASSEMBLY $=3156 \mathrm{~cm}^{2}$

\section{Cladding Area in One Scrap Basket}

The cladding surface area in a scrap basket is calculated based on the number of equivalent assemblies that could be in a scrap basket. The number of equivalent assemblies is calculated by dividing the $980 \mathrm{~kg}$ maximum net weight (uranium plus cladding and any other materials that may be present) allowed in a scrap basket for criticality purposes (Kessler 1998) by the weight of a full length Mark IV assembly (25.12 kg -- see section 4.2) to arrive at a value of 39.0 equivalent assemblies. The analys is above provides for the maximum number of equivalent elements and the maximum cladding surface area that can be loaded into a scrap basket, based on the criticality limits. Smaller, lighter Mark IA assemblies have lower criticality weight limits and thus result in fewer assemblies being allowed in a scrap basket.

\subsubsection{Uranium Surface Area}

Uranium surface areas have been the subject of in depth analyses. The values used in this report are obtained from the project technical baseline. An upper bound of $45,000 \mathrm{~cm}^{2}$ per basket has been establ ished for scrap baskets, and $7,900 \mathrm{~cm}^{2}$ has been established for fuel baskets (Ba11 1998). Nominal and low estimates of scrap and fuel reactive surface area are also documented in Ba11 1998. See section 5.2.1.2 for a detailed listing. 


\subsubsection{Particulate Density}

The theoretical density of uranium dioxide is $10.95 \mathrm{~g} / \mathrm{cc}$. The oxide layers on uranium surfaces will have lower than theoretical density. Hydrated layers would have a theoretical density half this value; but this can be considered explicitly for water content evaluations. All calculations used by this document to estimate adhering particulate mass are conservatively based on pure uranium dioxide at $10 \mathrm{~g} / \mathrm{cc}$.

A value of $2.7 \mathrm{~g} / \mathrm{cm}^{3}$ is used (section 5.2 .3 ) to estimate the mass of canister particulate that may be retained within fuel assembly flow channels. This value was obtained from [Pearce 1998]. That document lists the bulk density of $\mathrm{KW}$ Basin canister particulate as $2.68 \mathrm{~g} / \mathrm{cm}^{3}$, whereas it lists the bulk density of KE Basin canister particulate as $1.62 \mathrm{~g} / \mathrm{cm}^{3}$. All estimates in this document, regardless of which basin the fuel is from, are based on the higher of the two values $\left(2.7 \mathrm{~g} / \mathrm{cm}^{3}\right)$. 
HNF-1527, Rev. 2

\subsection{PARAMETERS, TECHNICAL BASES, AND ASSUMPTIONS}

\section{1 PARTICULATE LOCATIONS}

Particulates are films on the cladding and fuel surfaces, sludge deposits of canister particulate within the fuel assembly flow channels, and particles adhering to uranium at fuel damage locations, either openly exposed or lying beneath the surface of the cladding at the damage location. Accumutation of non-adherent beds of particles in vojds at ballooned element ends or in areas of peeled cladding on element sides is not expected, based on observations of particulate falling out of assemblies and causing notable turbid plumes during fuel handling. This is in contrast to tenaciousiy adhering particles found under mildly displaced cladding at failure Tocations. Particulate locations, as discussed in section 4.3, are summarized in Table 5.1.

Table 5.1: Particulate Locations

\begin{tabular}{||l|l|l|l||}
\hline MCO Location & \multicolumn{1}{|c|}{ Films } & Adhering Particulate & \multicolumn{1}{|c|}{$\begin{array}{c}\text { Canister } \\
\text { Particulate }\end{array}$} \\
\hline \hline Scrap Basket & $\begin{array}{l}\text { On cladding and } \\
\text { exposed uranium } \\
\text { surfaces }\end{array}$ & $\begin{array}{l}\text { On uranium surfaces } \\
\text { within/around damage } \\
\text { areas }\end{array}$ & $\begin{array}{l}\text { N/A -- See section } \\
5.2 .3 .1 \text { for a } \\
\text { discussion }\end{array}$ \\
\hline Fuel Basket & $\begin{array}{l}\text { On cladding and } \\
\text { exposed uranium } \\
\text { surfaces }\end{array}$ & $\begin{array}{l}\text { On uranium surfaces } \\
\text { within/around damage } \\
\text { areas }\end{array}$ & $\begin{array}{l}\text { Within flow } \\
\text { channels }\end{array}$ \\
\hline
\end{tabular}

\subsection{PARAMETERS}

Parameters used in this analysis can be categorized into fixed and variable parameters. Fixed parameters are those that are fixed by geometry or process design, and cannot or are not expected to vary significantiy. In instances where a parameter can have some minor variance, the maximum values are used. Table 5.2 1ists the parameters that are treated as fixed values.

Table 5.2: Fixed Parameters

\begin{tabular}{||l|l||}
\hline \multicolumn{1}{|c|}{ Item } & \multicolumn{1}{|c|}{ Value } \\
\hline \hline Cladding surface area & $3156 \mathrm{~cm}^{2}$ per assembly (see section 4.7.1) \\
\hline Uranium oxide density & $10 \mathrm{~g} / \mathrm{cc}$ (See section 4.7.3) \\
\hline Canister particulate density & $2.7 \mathrm{~g} / \mathrm{cc}$ (See section 4.7.3) \\
\hline
\end{tabular}


Three configurations of scrap and fuel baskets are considered: 1). Five fuel baskets; 2) One scrap basket and four fuel baskets; and 3) Two scrap baskets and three fuel baskets.

Based on characterization data and process design, several parameters used in this analysis are expected to either vary significantly or cannot be precisely quantified. These parameters are: 1) surface films; 2) adhering particulate; 3) canister particulate; and, 4) uranium surface areas. High, best estimate, and low values were assigned to these parameters.

Three estimate values are chosen because: 1) realistic expectations and variability in the quantities are addressed by considering more than just a high value, with the result that the estimates are more physically based; 2) the reason for selection of the high value is better understood in relation to choice of the best-estimate; 3 ) it is easier to understand these estimates than to intuitively grasp the meaning of more complex probability density functions ( $p f d s$ ); and 4) pdfs with greater detail are simply not justified by the data. Definitions of these values are:

- High The contents of any MCO are not reasonably expected to exceed a particulate quantity derived using the high parameter value. Locally, some fuel or scrap could have parameter values that exceed those assumed for the high value, but it would be unreasonable and inappropriate to assign such a value to calculate the contents of an entire MCO.

- Best Est The contents of most MCOs are wel1-represented by this value, although local variation within a given $M C O$ is expected.

- Low The contents of an MCO could occasionally be characterized by this value.

\subsubsection{Surface Films}

Surface films consist of films on intact cladding and films on exposed uranium surfaces. The cladding surface films can vary significantly in form and amount on the fuel elements that have been observed and characterized. The cladding on most elements has a thin grayish colored film. The cladding surface on some elements contains a heavier, whitish coating. This material was determined to be approximately 90 percent aluminum hydroxide by a combination of X-Ray Diffraction and Inductively Coupled Plasma (ICP) techniques (Sloughter 1998). The amount of the film varies by over an order of magnitude. 
5.2.1.1 Cladding Films. Visual examinations show that the grayish coating is prevalent on all $\mathrm{K}$ East assemblies. Analyses have shown this material to be uranium oxide compounds. The white coating was observed on assemblies stored in closed aluminum canisters in $\mathrm{K}$ West Basin. About 25 percent of the assemblies in $\mathrm{K}$ West Basin are stored in closed aluminum canisters. Based on these measured values, and applying them to all assemblies in an MCO, the following high, best estimate, and low values for film contributions were established for the analysis.

Mass per unit area of layer, $(\mathrm{m} / \mathrm{A})_{\text {layer }}$

- High $12.5 \mathrm{mg} / \mathrm{cm}^{2}$ Based on statistical analys is of cladding thickness measurements made by eddy current techniques.

- Best Est $3.54 \mathrm{mg} / \mathrm{cm}^{2}$ Weighted average, assuming that $25 \%$ of the assemblies have the white layer, at $12.5 \mathrm{mg} / \mathrm{cm}^{2}$, and that $75 \%$ have the gray layer, with an estimated mass per unit area of $0.55 \mathrm{mg} / \mathrm{cm}^{2}$

- Low $\quad 0.55 \mathrm{mg} / \mathrm{cm}^{2} \quad \begin{aligned} & \text { Most fue] elements have the gray layer with an } \\ & \text { estimated mass per unit area of } 0.55 \mathrm{mg} / \mathrm{cm}^{2}\end{aligned}$

5.2.1.2 Uranium Surface Films. High, best estimate, and low values for uranium surface film volume and mass are calculated from the values for film thickness and fitm area given below.

\section{Film Thickness}

Uranium surface oxide films have been measured in the laboratory. The thickness on most elements is from 2 to 3 microns. One sample heated and held at elevated temperature had a measured thickness of 10 microns.

Thickness of uranium surface film, $\delta_{\text {layer }}$

- High $\quad 10 \mu \mathrm{m}$ Three times nominal reported observation and equivalent to value measured on treated specimen.

- Best Est $3 \mu \mathrm{m}$ Reported observation. Data ranges are small, and therefore the maximum reported value was chosen.

- Low $\quad 3 \mu \mathrm{m}$. Ranges of observed thickness is small. No compelling reason to consider a lower value. 


\section{Fi]m Area}

Exposed uranium areas have been evaluated extensively. High values from existing project technical baselines have been used in this analysis. High, best estimate, and low values used are given below:

\section{Exposed area of scrap, $A_{o x}$ scrap}

- High $45,000 \mathrm{~cm}^{2} /$ basket From Ball 1998

- Best Est $17,000 \mathrm{~cm}^{2} /$ basket From Ball 1998

- Low $10,000 \mathrm{~cm}^{2} /$ basket Scrap can consist of damaged assembilies with few "fine" fragments by its definition.

Exposed area of fuel, $A_{o x}$, fuel

- High $7,900 \mathrm{~cm}^{2} /$ basket From Bal1 1998

- Best Est $425 \mathrm{~cm}^{2} /$ basket From Ball 1998

- Low $160 \mathrm{~cm}^{2} /$ basket From Ball 1998 , based on $\mathrm{KW}$

basin data. Values not established from KE Basin

5.2.2 Adhering Particulates. Values for adhering particulates are established based on fuel survey data and characterization of elements.

5.2.2.1 Scrap Basket. High, best estimate, and low values for the particulate content of a scrap basket are given below.

Mass of particulate per equivalent assembly in scrap basket, $m_{\text {par, assy, scrap }}$

- High $200 \mathrm{~g}$ An order of magnitude greater than the largest observed particulate mass on an element, $20 \mathrm{~g}$ (Pitner 1997c); the particular assembly selected was among the worst observed. The value is about $1 \%$ of the mass of an assembly and it is deemed incredible that such a mass of particles would survive cleaning. The value is equivalent to a particle layer about $1 \mathrm{~mm}$ thick if $10 \%$ of the assembly area were damaged, indicating that cladding would have to be badly deformed to retain such particles, lending credibility to the cleaning assumption. This value accounts for any deposits of canister particulate and contributions of both inner and outer elements because it is so large, and the damage fraction of inner elements is smal1.

- Best Est $20 \mathrm{~g}$ This is the worst measured vaTue, taken from an element destined for a scrap basket, so it is at least representative of scrap.

- Low $6 \mathrm{~g} \quad$ Lowest measured value. 
HNF-1527, Rev. 2

\section{Alternate Method for Scrap Basket}

An alternate method for estimating high values for adhering particulate in the scrap basket was also evaluated. The primary method described above used the highest particulate recovery from an assembly in laboratory measurements (20 $\mathrm{g}$ per assembly) and a factor of 10 multiplier to arrive at $200 \mathrm{~g}$ per equivalent assembly. In the alternate method the data from the laboratory are applied differently. The highest amount of particulate recovered from the damaged portion of an assembly is calculated. This value is derived in terms of grams of particulate per lineal centimeter of the damaged portion. The high value for damaged fuel in a scrap basket assumes that all equivalent assemblies are damaged the full length and have the maximum particulate loading.

The highest quantity of particulate recovered was $15.5 \mathrm{~g}$ from the top of element 5427E. The damaged portion was about $8 \mathrm{~cm}$ long, therefore the particulate Toading is $15.5 \mathrm{~g} / 8 \mathrm{~cm}=2$ grams per lineal centimeter of the damage region. Using a bounding value of 39 equivalent assemblies per scrap basket and an assembly length of $66 \mathrm{~cm}$, the total equivalent assembly length would be 39 assemblies * $66 \mathrm{~cm}$ per assembly $=2574 \mathrm{~cm}$. Multiplying by the loading factor of $2 \mathrm{~g} / \mathrm{cm}$ gives a particulate mass of $5.2 \mathrm{~kg}$, which is 1 ower than the high value calculated using the primary method. This alternate method corresponds to a scrap basket loaded with $8 \mathrm{~cm}$ long assembly sections with the amount of damage seen on element 5427E (Figure 13). The primary method assigned a loading of $200 \mathrm{~g}$ per equivalent assembly and arrived at a total mass of $7.8 \mathrm{~kg}$. The $7.8 \mathrm{~kg}$ value is more conservative than the alternate calculation and is therefore adopted for this analysis.

5.2.2.2 Fuel Basket. High, best estimate, and low values for the particulate content of a fuel basket are given below.

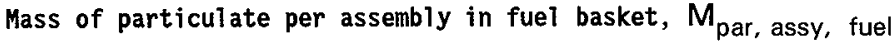

- High $20 \mathrm{~g}$ Fuel cannot look worse than scrap. This assumes that all the fuel loaded into all four fuel baskets corresponds to fue] assemblies similar to element 5427 (Figure 13), which represents the highest measured value taken from an element destined for a scrap basket.

- $\quad$ Best Est $7.6 \mathrm{~g}$

$38 \%$ of fuel elements are defective (Table 4.2 ), hence $38 \%$ is applied to the high value to create the best estimate.

- Low $\quad 1.3 \mathrm{~g}$ Most fuel assemblies are not signifjcantly damaged. An MCO with one canister pair containing damaged fuel would have a value $14 / 216$, or $6.5 \%$ of the high value. The low value could well be zero, but is not considered important. 
HNF-1527, Rev. 2

\subsubsection{Canister Particulate}

As discussed in section 4.3 , deposits of canister particulate may be present in fuel assembly flow channels. This particulate is easily mobilized and is observed to cloud the water when disturbed (note that most of it re-settles rapidly). Fuel handling and washing operations are designed to remove canister particulate from the fuel elements and fragments, including any accumulations within the assembly flow channels.

5.2.3.1 Scrap Basket. Because some scrap baskets will contain some complete fuel assemblies due to excessive damage on one or both ends, scrap baskets have the potential to retain canister particulate within fuel assembly flow channels. However, no canister particulate is allocated to scrap baskets (see Tables 5.1 and 6.1) because of the relatively large decrease in adhering particulate that will accompany the small amount of canister particulate that accrues as the high surface area scrap pieces are replaced by essentially intact, low surface area, fuel elements (i.e., it is regarded as a trade-off).

5.2.3.2 Fuel Basket. Accumulation of canister particulate with in fuel assembly flow channels has only been observed on one occasion, and essentially none is expected to remain within the assemblies after cleaning (see section 4.3). However, given the relatively long, narrow flow channels within an intact fuel assembly, it must be assumed that there is some potential for a deposit to survive the cleaning process. Therefore, it will be necessary to establish an upper bound for deposits of canister particulate within freshly cleaned, intact fuel assemblies. This can be accomplished by developing an appropriate set of acceptance criteria for the fuel cleaning process validation testing activity (Shen 1997).

In conjunction with the overall fuel cleaning process validation testing protocol, the canister particulate removal criteria will-provide a $99 \%$ confidence (see section 5.2.3.2.1) that no fuel basket will contain more than $118 \mathrm{~cm}^{3}$ of canister particulate.

After initial startup testing, a limited number of fuel canisters will be processed through the fuel cleaning machine while the operating parameters are controlled within defined ranges in order to validate the fuel cleaning process. Following completion of the validation testing, acceptable operation of the cleaning machine will be periodically confirmed on a sampling basis.

During validation testing and follow-on sampling, the inner element will be removed from the outer element of each freshly cleaned fuel assembly, and both the outside surface and the bore of each element will be inspected to determine if the associated assembly passes a per-assembly cleaning criterion.

Based on the number of assemblies from a given canister that fail the perassembly cleaning criterion, the canister that contained them will either pass or fail a related per-canister criterion.

Finally, based on the number of canisters and/or individual assemblies that fail an overall test-batch criterion, the cleaning process either meets, or fails to meet, the cleaning process validation criteria for removal of canister particulate. If the validation criteria are not met, the cleaning machine operating parameters will be adjusted and the validation test will be repeated. The testing, adjusting, and re-testing must continue until the validation criteria are met prior to injtiating routine operations. 
HNF-1527, Rev. 2

The per-canister cleaning criteria basis utilizes the per-assembly cleaning criterion, based on a pre-defined number of canisters forming a canister batch in the process validation test:

- If one assembly in a canister fails the assembly cleaning criterion, then the canister fails the canister cleaning criterion, and there can be no more than one more assembly in the canister batch that fails the assembly cleaning criterion.

- If two assemblies in a canister fail the assembly cleaning criterion, then the canister fails the canister cleaning criterion, and no more assemblies in the canister batch can fail the assembly cleaning criteria.

- If three assemblies in a process validation test batch fail the assembly cleaning criteria, then the batch fails the process validation test.

The per-assembly process acceptance criterion is developed below, based on a process validation test batch size of 29 canisters. Meeting the overall process validation acceptance criteria (i.e., the per-assembly, per-canister, and per-test-batch criteria) with this batch size provides a $99 \%$ confidence that no more than $15 \%$ of the canisters will fail to meet the per-canister criteria.

The per-assembly cleaning criterion is based on defining the quantity of particulate observed to remain in flow channels after cleaning that would cause an assembly to be considered inadequately cleaned. The definition of an assembly that fails the per-assembly cleaning criterion is:

An assembly fails the cleaning criterion if, when removing the inner element from the outer element, and/or upon subsequent inspection of both elements, the total quantity of particulate observed is equivalent to a cone that is 1-inch in diameter (size of a quarter) at the base and $0.3-$ inch high (based on a worst case $\left[30^{\circ}\right]$ angle of repose):

$$
\begin{aligned}
& r=1 / 2-\text { inch; } h=r^{*} \operatorname{Tan} 30^{\circ}=(1 / 2) * 0.5774=0.289-\text { inch; } \\
& \text { USE } h=0.3 \text {-inch. }
\end{aligned}
$$

The volume of the above right circular cone is given by $V=1 / 3 * h * \pi * R^{2}$ where; $V=$ volume in $\mathrm{cm}^{3} ; \mathrm{h}=$ height in $\mathrm{cm}$; and $\mathrm{R}=$ radius of base in $\mathrm{cm}$; $V=1 / 3 * 0.3 * 2.54 * \pi * R^{2}=0.798 * R^{2}=0.798 *(2.54 / 2)^{2}=0.798 * 1.61=$ $1.28 \mathrm{~cm}^{3}$; USE $1.3 \mathrm{~cm}^{3}$.

The per-assembly cleaning criterion is designed to ensure that any assembly which satisfies it contains no more than $1.3 \mathrm{~cm}^{3}$ of canister particulate, such that passing the process validation test provides a $99 \%$ confidence that no more than $15 \%$ of the canisters contain an assembly that has retained over 1.3 $\mathrm{cm}^{3}$ of canister particulate after undergoing the cleaning process. In addition, a passing canister batch (of 406 assemblies) can contain no more than two assemblies that have each retained over $1.3 \mathrm{~cm}^{3}$ of canister particulate. 
Failure of the assembly cleaning criteria is assumed to imply that each assembly flow channel contains a $3-$ inch $(7.6 \mathrm{~cm}$ ) plug (average observed particulate depth in canisters [Pitner 1996]). Given the assumption that both flow channels are plugged, an assembly failing the cleaning criterion is estimated to contain $57 \mathrm{~cm}^{3}$ of canister particulate: $V_{\text {tot }}=V_{\text {inner }}+V_{\text {annulus }}$

I.D. of Inner $=1.22 \mathrm{~cm}($ Table 4.1$) ; R_{\text {inner }}=1.22 / 2 \mathrm{~cm} ; \mathrm{h}=7.6 \mathrm{~cm}$; $V_{\text {inner }}=h^{*} \pi * R^{2}=7.6 \mathrm{~cm} * \pi * R^{2}=23.88 \mathrm{~cm} *(1.22 / 2 \mathrm{~cm})^{2}=8.9 \mathrm{~cm}^{3}$

I.D. of Outer $=4.32 \mathrm{~cm}--R_{1}=4.32 / 2=2.16 \mathrm{~cm}$;

$0 . D$. of Inner $=3.25 \mathrm{~cm}-R_{2}=3.25 / 2=1.63 \mathrm{~cm}$;

$$
\begin{aligned}
& V_{\text {annulus }}=h^{*} \pi^{*}\left(R^{2}-R^{2}\right)=23.88 \mathrm{~cm} *\left(2.16^{2} \mathrm{~cm}-1.63^{2} \mathrm{~cm}\right)= \\
& 23.88 \mathrm{~cm} *\left(4.67 \mathrm{~cm}^{2}-2.64 \mathrm{~cm}^{2}\right)=23.88 \mathrm{~cm} * 2.03 \mathrm{~cm}^{2}=48.5 \mathrm{~cm}^{3} \\
& V_{\text {tot }}=V_{\text {inner }}+V_{\text {annulus }}=8.9 \mathrm{~cm}^{3}+48.5 \mathrm{~cm}^{3}=57.4 \mathrm{~cm}^{3} ; \text { USE } 57 \mathrm{~cm}^{3}
\end{aligned}
$$

Based on the above, the allocation for canister particulate in flow channels for a batch of 29 canisters containing 406 fuel assemblies (29 canisters 14 assemblies each $=406$ assemblies) can be expressed by the following terms:

- Volume of canister particulate within those assemblies that met the perassembly criterion is $1.3 \mathrm{~cm}^{3} \times 406$ assembles, or $523 \mathrm{~cm}^{3}$;

- Volume from those canisters (15\%) that could still contain one failed assembly, based on the statistics associated with a $99 \%$ confidence level on a 29 canister test batch, is $0.15 \times 29$ canisters per batch $\times 57 \mathrm{~cm}^{3}$ per assembly, or $248 \mathrm{~cm}^{3}$;

- Volume from the two assemblies that are allowed (by the per-test-batch criterion) to fail the cleaning criteria is $2 \times 57 \mathrm{~cm}^{3}$, or $114 \mathrm{~cm}^{3}$.

The maximum volume of canister particulate per batch of 406 assemblies is the 1) sum of the above values: $523 \mathrm{~cm}^{3}+248 \mathrm{~cm}^{3}+114 \mathrm{~cm}^{3}=885 \mathrm{~cm}^{3}$. The maximum number of fuel assemblies that can be placed into one fuel basket is 54 (Smith 1998). Therefore the maximum volume of canister particulate that can be loaded into one fuel basket is $(54 / 406)^{*}\left(885 \mathrm{~cm}^{3}\right)=118 \mathrm{~cm}^{3}$. Given a bulk density of $2.7 \mathrm{~g} / \mathrm{cm}^{3}$ (see section 4.7 .3 ) the high value for the canister particulate inventory of a fuel basket is $2.7 \mathrm{~g} / \mathrm{cm}^{3} \times 118 \mathrm{~cm}^{3} /$ basket $=319 \mathrm{~g}$; USE $320 \mathrm{~g}$. 
5.2.3.2.1 Minimum Sample Size to Achieve 99\% Confidence. The minimum sample size required to achieve a $99 \%$ confidence that no more than $15 \%$ of the canister population will fail the cleaning criteria is derived from the following equation (from Shen 1997):

$$
n=0.5\left(1-B^{1 / D a}\right)\left(2 N-D_{a}+1\right)
$$

where

$$
\begin{aligned}
& n=\text { the number of canisters processed during validation testing } \\
& B=\text { the probability of stating an item is clean when it is not clean } \\
& D_{a}=\text { the number of defects allowed with probability } B \\
& N=\text { the total number of } N \text { Reactor fuel, canisters within the basin }
\end{aligned}
$$

Basis for selection of $\mathbb{N}$

The total number of fuel canisters within the KW Basin is 3841, of which "... approximately 30 ..." contain Single Pass Reactor (SPR) fuel (Praga 1998). The total number of $\mathrm{KW}$ Basin canisters containing $N$ Reactor fuel is therefore on the order of $3841-30=3811$ canisters -- USE $N=3820$ Canisters.

\section{Basis for selection of $B$}

If the confidence is to be 0.99 , then the probability for error ( $B$ ) must be equal to $1.00-0.99=0.01$.

\section{Basis for selection of $\mathrm{D}_{\mathrm{a}}$}

If the validation testing is to confirm (at any given confidence level) that no more than $15 \%$ of the canister population would have failed the validation test (were it to be performed on every canister within the basin), then the number of defects $\left(D_{a}\right)$ must be equal to the total canister population (3820) times $0.15=0.15 * 3820=573$ defects.

Based on the above, the minimum required sample size ( $n$ ) is given by:

$$
\begin{aligned}
n= & \left.0.5\left(1-0.01^{1 / D a}\right)(2 * 3820-573+1)\right]=0.5\left(1-0.01^{1 / 573}\right)(7068)= \\
& 3534(1-0.991995)=3534(0.0080)=28.29 ; \text { USE } 29 \text { Canisters. }
\end{aligned}
$$

5.2.3.2.2 Basis for Best Estimate. In view of the evidence that the flow channels of most fuel assemblies will contain little or no particulate prior to cleaning, let alone after cleaning, it should be reasonable to assume that the total canister particulate content of a nominal fuel basket wi11 not exceed that portion of the high estimate that is associated with assemblies that would have failed the per-assembly cleaning criterion, with no allowance for any canister particulate from those assemblies that would have met the criterion. From the above discussion, this amounts to $248 \mathrm{~cm}^{3}+114 \mathrm{~cm}^{3}=362$ $\mathrm{cm}^{3}$ per 406 assembly validation batch. At 54 fuel assemblies per basket, that translates to $54 / 406 \times 362 \mathrm{~cm}^{3}=48 \mathrm{~cm}^{3}$ per basket. At $2.7 \mathrm{~g} / \mathrm{cm}^{3}$, the resulting mass of canister particulate within a nominal fuel basket would be $2.7 \mathrm{~g} / \mathrm{cm}^{3} \times 48 \mathrm{~cm}^{3} /$ basket $=130$ grams . 
HNF-1527, Rev. 2

\section{Canister particulate mass per fuel basket:}

- High $700 \mathrm{~g} /$ basket The bounding value is based on the cleaning process validation criteria

- Best Est $130 \mathrm{~g} /$ basket Assumes pluggage per above, but without the bounding allowance of $4.3 \mathrm{~cm}^{3}$ per assembly

- Low 0 No canister particulate deposits

\subsection{ASSUMPTIONS}

Other key assumptions used in this analysis are:

Fuel elements described as "bad" are assumed to be $\mathrm{placed}$ in scrap baskets (Pitner 1998).

Formation of white layers in local spots and the presence of local reddish spots are considered to be included in the "high" estimate.

While no credit is taken for the cleaning equipment's ability to remove any of the white layer that was measured on fuel element samples, the estimate does assume that the cleaning process will be at least as effective as the limited cleaning obtained from transporting the fuel elements to the laboratory.

The above statement should not be taken to imply that "adhering particulate" would be readily available for release from an $\mathrm{MCO}$. What it does imply is that the adhering particulate estimate is both reasonable (in that it does not include the particulate that was found on the bottom of the transfer cask) and conservative (in that it does include all of the particulate that was recovered from the sample, even though the sample had not been cleaned). The adhering particulate category is intended to represent only those materials that are very difficult to remove (see the fifth paragraph of section 4.6). 


\subsection{CALCULATION}

\subsection{SCOPE OF CALCULATION}

The calculation considers materials which may be loaded into an MCO that are literally not cladding and fuel in their original form.

\subsection{MASS CALCULATION EQUATIONS}

Particulate masses are calculated for cladding and uranium surface area films, adhering particulates, and canister particulate deposits loaded into the MCO. The mass values are calculated for scrap and fuel.

1. Cladding Film -- Scrap. The associated mass is given by:

$$
M_{\text {layer }}=A_{\text {assy }} N_{\text {assy }}(m / A)_{\text {layer }}
$$

where

$$
\begin{aligned}
& M_{\text {layer }}=\text { Layer mass, } \mathrm{kg} \\
& A_{\text {assy }}=\text { Assembly area, } \mathrm{cm}^{2} \\
& N_{\text {assy }}=\text { Number of assemblies, fuel plus scrap } \\
& (\mathrm{m} / \mathrm{A})_{\text {layer }}=\text { Mass per unit area of layer, } \mathrm{kg} / \mathrm{cm}^{2}
\end{aligned}
$$

The area of an assembly is given by the geometric data in section 4.2:

$$
A_{\text {assy }}=3156 \mathrm{~cm}^{2}
$$

The number of equivalent assemblies in a scrap basket is determined by the scrap basket weight limit divided by the average weight of an assembly:

$$
N_{\text {assy }}=(980 \mathrm{~kg} / \mathrm{scrap} \text { basket }) /(25.12 \mathrm{~kg} / \text { assembly })=39.0
$$

Mass per unit area of the layer values are defined in section 5.2. 
2. Cladding Film -- Fuel. The associated mass is given by equation (2), with the exception that the number of fuel assemblies is taken as the sum of fuel assemblies for an MCO with four fuel baskets:

$$
N_{\text {assy, fuel }}=4 * 54=216
$$

3. 0xide Film -- Scrap. All exposed uranium metal should have some oxide film because some corrosion must have occurred. Scrap is considered separately from fuel because the area for scrap is deduced differently than the area for fuel. The mass of an oxide layer is given by:

where

$$
M_{o x, \text { scrap }}=A_{o x, \text { scrap }}(m / A)_{o x}
$$

$$
\begin{aligned}
M_{\text {ox }, \text { scrap }} & =\text { Oxide mass on scrap, } \mathrm{kg} \\
A_{\mathrm{ox}, \text { scrap }} & =\text { Oxidation area of scrap, } \mathrm{m}^{2} \\
\langle\mathrm{~m} / \mathrm{A})_{\mathrm{ox}} & =\text { Mass per unit area oxide layer, } \mathrm{kg} / \mathrm{m}^{2}
\end{aligned}
$$

The area $A_{o x}$ scrap is chosen as discussed in Section 5.2.

The mass per unit area is further decomposed as the product of layer thickness and density:

where

$$
(\mathrm{m} / \mathrm{A})_{\mathrm{ox}}=\rho_{\text {layer }} \delta_{\text {layer }}
$$

$$
\rho_{\text {layer }}=\text { Layer density, } \mathrm{kg} / \mathrm{m}^{3}
$$

4. Oxide Layer -- Fue1. Fuel in fuel baskets has areas with cladding failure and the exposed metal must have some oxide layer. The mass of this oxide is given by the same formula as for the scrap basket oxide:

$$
M_{\text {ox } \text { fuel }}=A_{\text {ox, fuel }}(\mathrm{m} / \mathrm{A})_{\text {ox }}
$$

The exposed area is defined in section 5.2 and the mass per unit area is chosen in the same way as for that in the scrap basket. 
5. Particulate on Scrap. Particulate is found to be associated with failed areas, both on the failed area and underneath adjacent cladding that has become unbonded from the fuel (Figures 16 and 17). Particulates associated with fuel and scrap are considered separately because the damage in scrap is more extensive than it is in fuel. The mass of particulate associated with scrap is given by:

$$
M_{\text {par, scrap }}=N_{\text {assy, scrap }} m_{\text {par, assy }}
$$

where

$$
\begin{aligned}
& M_{\text {par, scrap }}=\text { Particulate mass on scrap, } \mathrm{kg} \\
& m_{\text {par, assy }}=\text { Mass of particulate per assembly, } \mathrm{kg}
\end{aligned}
$$

The mass of particulate per assembly in a scrap basket is given in section 5.2.

6. Particulate on Fuel. Similariy, particulate may be found on the failed area and locally underneath adjacent cladding on fuel assemblies in fuel baskets. The total mass is given by:

$$
M_{\text {par, fuel }}=N_{\text {assy, fuel }} m_{\text {par, assy }}
$$

The mass of particulate per assembly in a fuel basket is given in section 5.2 . 


\subsection{RESULTING PARTICULATE MASS VALUES}

Calculations of particulate values are on an MCO basis shown below for three cases. Results are rounded to yield the overall values summarized in Table 6.1.

\subsubsection{Case 1: Zero Scrap Baskets - Five Fuel Baskets}

1. Cladding Surface Film, Fuel

High: $3156 \mathrm{~cm}^{2} /$ assy * 270 assy $* 1.25 * 10^{-5} \mathrm{~kg} / \mathrm{cm}^{2}=10.65 \mathrm{~kg}$

Best Est: $3156 \mathrm{~cm}^{2} /$ assy * 270 assy * $3.54 * 10^{-6} \mathrm{~kg} / \mathrm{cm}^{2}=3.02 \mathrm{~kg}$

Calculation for Break Down by Film Type Reported in Table 6.1 Al $(\mathrm{OH})_{3}: 3156 \mathrm{~cm}^{2} /$ assy*0.25*270 assy* $12.5 * 10^{-6} \mathrm{~kg} / \mathrm{cm}^{2}=2.663 \mathrm{~kg}$

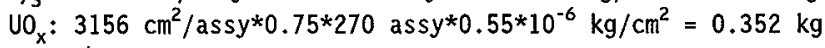

Low: $3156 \mathrm{~cm}^{2} /$ assy * 270 assy * $5.5^{*} 10^{-7} \mathrm{~kg} / \mathrm{cm}^{2}=0.47 \mathrm{~kg}$

2. Oxide Film, Fuel

High: $7900 \mathrm{~cm}^{2} /$ basket * 5 baskets $10 * 10^{-4} \mathrm{~cm} * 0.01 \mathrm{~kg} / \mathrm{cm}^{3}=0.395 \mathrm{~kg}$

Best Est: $425 \mathrm{~cm}^{2} /$ basket $* 5$ baskets $3 * 10^{-4} \mathrm{~cm} * 0.01 \mathrm{~kg} / \mathrm{cm}^{3}=0.0064 \mathrm{~kg}$ Low: $160 \mathrm{~cm}^{2} /$ basket * 5 baskets $3 * 10^{-4} \mathrm{~cm} * 0.01 \mathrm{~kg} / \mathrm{cm}^{3}=0.0024 \mathrm{~kg}$

3. Particulate on Fuel

High: $0.02 \mathrm{~kg} /$ assy * 270 assy $=5.40 \mathrm{~kg}$

Best Est: $0.0076 \mathrm{~kg} /$ assy $* 270$ assy $=2.05 \mathrm{~kg}$

Low: $0.0013 \mathrm{~kg} /$ assy * 270 assy $=0.35 \mathrm{~kg}$

4. Canister Particulate

High: 5 baskets $* 0.32 \mathrm{~kg} /$ basket $=1.6 \mathrm{~kg}$

Best Est: 5 baskets $* 0.13 \mathrm{~kg} /$ basket $=0.65 \mathrm{~kg}$

Low: 5 baskets $* 0 \mathrm{~kg} /$ basket $=0 \mathrm{~kg}$ 


\subsubsection{Case 2: One Scrap Basket - Four Fuel Baskets}

1. Cladding Surface Film, Scrap

High: $3156 \mathrm{~cm}^{2} /$ assy * 39 assy * $1.25 * 10^{-5} \mathrm{~kg} / \mathrm{cm}^{2}=1.54 \mathrm{~kg}$

Best-Est: $3156 \mathrm{~cm}^{2} /$ assy * 39 assy $* 3.54 * 10^{-6} \mathrm{~kg} / \mathrm{cm}^{2}=0.44 \mathrm{~kg}$

Calculation for Break Down by Film Type Reported in Table 6.1 Al $(\mathrm{OH})_{3}: 3156 \mathrm{~cm}^{2} /$ assy*0.25*39 assy* $12.5 * 10^{-6} \mathrm{~kg} / \mathrm{cm}^{2}=0.385 \mathrm{~kg}$

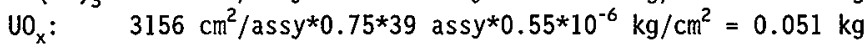
Low: $3156 \mathrm{~cm}^{2} /$ assy * 39 assy * $5.5 * 10^{-7} \mathrm{~kg} / \mathrm{cm}^{2}=0.07 \mathrm{~kg}$

2. Cladding Surface $F i l m$, Fue 1

High: $3156 \mathrm{~cm}^{2} /$ assy * 216 assy * $1.25 * 10^{-5} \mathrm{~kg} / \mathrm{cm}^{2}=8.51 \mathrm{~kg}$ Best Est: $3156 \mathrm{~cm}^{2} /$ assy * 216 assy * $3.54 * 10^{-6} \mathrm{~kg} / \mathrm{cm}^{2}=2.41 \mathrm{~kg}$

Calculation for Break Down by Film Type Reported in Table 6.1 $\mathrm{Al}(\mathrm{OH})_{3}: 3156 \mathrm{~cm}^{2} /$ assy*0.25*216 assy* $12.5^{*} 10^{-6} \mathrm{~kg} / \mathrm{cm}^{2}=2.13 \mathrm{~kg}$

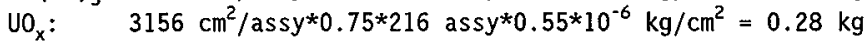
Low: $3156 \mathrm{~cm}^{2} /$ assy * 216 assy $* 5.5 * 10^{-7} \mathrm{~kg} / \mathrm{cm}^{2}=0.38 \mathrm{~kg}$

3. Oxide Film, Scrap

High: $45,000 \mathrm{~cm}^{2} /$ basket $* 1$ basket $* 10^{\star} 10^{-4} \mathrm{~cm}^{\star} 0.01 \mathrm{~kg} / \mathrm{cm}^{3}=0.450 \mathrm{~kg}$ Best Est: $17,000 \mathrm{~cm}^{2} /$ basket*1 basket $* 3 * 10^{-4} \mathrm{~cm}^{*} 0.01 \mathrm{~kg} / \mathrm{cm}^{3}=0.051 \mathrm{~kg}$ Low: $10,000 \mathrm{~cm}^{2} /$ basket $* 1$ basket $* 3 * 10^{-4} \mathrm{~cm}^{*} 0.01 \mathrm{~kg} / \mathrm{cm}^{3}=0.030 \mathrm{~kg}$

4. Oxide Film, Fuel

High: $7,900 \mathrm{~cm}^{2} /$ Basket*4 baskets $* 10 * 10^{-4} \mathrm{~cm}^{* 0} 0.01 \mathrm{~kg} / \mathrm{cm}^{3}=0.32 \mathrm{~kg}$

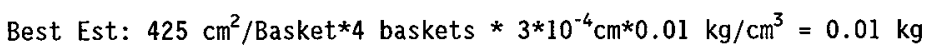
Low: $160 \mathrm{~cm}^{2} /$ Basket*4 baskets $* 3 * 10^{-4} \mathrm{~cm} * 0.01 \mathrm{~kg} / \mathrm{cm}^{3}=0.0019 \mathrm{~kg}$

5. Particulate on Scrap

High: $0.2 \mathrm{~kg} /$ assy * 39 assy $=7.8 \mathrm{~kg}$

Best-Est: $0.02 \mathrm{~kg} /$ assy * 39 assy $=0.78 \mathrm{~kg}$

Low: $0.006 \mathrm{~kg} /$ assy $* 39$ assy $=0.23 \mathrm{~kg}$ 
HNF-1527, Rev. 2

6. Particulate on Fuel

High: $0.02 \mathrm{~kg} /$ assy $* 216$ assy $=4.32 \mathrm{~kg}$

Best Est: $0.0076 \mathrm{~kg} /$ assy * 216 assy $=1.64 \mathrm{~kg}$

Low: $0.0013 \mathrm{~kg} /$ assy $* 216$ assy $=0.28 \mathrm{~kg}$

7. Canister Particulate

High: 4 baskets $* 0.32 \mathrm{~kg} /$ basket $=1.28 \mathrm{~kg}$

Best Est: 4 baskets $* 0.13 \mathrm{~kg} /$ basket $=0.52 \mathrm{~kg}$

Low: 4 baskets $* 0 \mathrm{~kg} /$ basket $=0$

\subsubsection{Case 3: Two Scrap Baskets - Three Fuel Baskets}

1. Cladding Surface Film, Scrap

High: $3156 \mathrm{~cm}^{2} /$ assy $* 78$ assy $* 1.25 * 10^{-5} \mathrm{~kg} / \mathrm{cm}^{2}=3.08 \mathrm{~kg}$

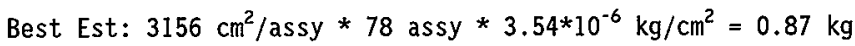

Calculation for Break Down by Film Type Reported in Table 6.1 Al $(\mathrm{OH})_{3}: 3156 \mathrm{~cm}^{2} /$ assy*0.25*78 assy* $12.5^{*} 10^{-6} \mathrm{~kg} / \mathrm{cm}^{2}=0.769 \mathrm{~kg}$

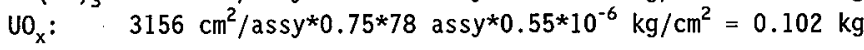

Low: $3156 \mathrm{~cm}^{2} /$ assy * 78 assy * $5.5^{*} 10^{-7} \mathrm{~kg} / \mathrm{cm}^{2}=0.14 \mathrm{~kg}$

2. Cladding Surface Film, FueT

High: $3156 \mathrm{~cm}^{2} /$ assy 162 assy * $1.25 * 10^{-5} \mathrm{~kg} / \mathrm{cm}^{2}=6.39 \mathrm{~kg}$

Best Est: $3156 \mathrm{~cm}^{2} /$ assy 162 assy $* 3.54 * 10^{-6} \mathrm{~kg} / \mathrm{cm}^{2}=1.81 \mathrm{~kg}$

Calculation for Break Down by Film Type Reported in Table 6.1 Al $(\mathrm{OH})_{3}: 3156 \mathrm{~cm}^{2} /$ assy*0.25*162 assy* $12.5^{*} 10^{-6} \mathrm{~kg} / \mathrm{cm}^{2}=1.598 \mathrm{~kg}$

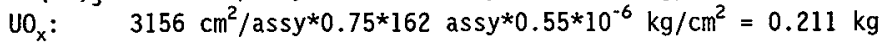
Low: $3156 \mathrm{~cm}^{2} /$ assy 162 assy $* 5.5^{*} 10^{-7} \mathrm{~kg} / \mathrm{cm}^{2}=0.28 \mathrm{~kg}$

3. Oxide Film, Scrap

High: $45,000 \mathrm{~cm}^{2} /$ Basket*2 Baskets $* 10 * 10^{-4} \mathrm{~cm}^{*} 0.01 \mathrm{~kg} / \mathrm{cm}^{3}=0.9 \mathrm{~kg}$ Best Est: $17,000 \mathrm{~cm}^{2} /$ Basket*2 Baskets $* 3 * 10^{-4} \mathrm{~cm}^{*} 0.01 \mathrm{~kg} / \mathrm{cm}^{3}=0.1 \mathrm{~kg}$ Low: $10,000 \mathrm{~cm}^{2} /$ Basket*2 Baskets $* 3 * 10^{-4} \mathrm{~cm}^{*} 0.01 \mathrm{~kg} / \mathrm{cm}^{3}=0.06 \mathrm{~kg}$ 
4. Oxide FiTm, Fuel

High: $7900 \mathrm{~cm}^{2} /$ Basket*3 Baskets * $10 * 10^{-4} \mathrm{~cm} * 0.01 \mathrm{~kg} / \mathrm{cm}^{3}=0.24 \mathrm{~kg}$

Best Est: $425 \mathrm{~cm}^{2} /$ Basket*3 Baskets $* 3 * 10^{-4} \mathrm{~cm} * 0.01 \mathrm{~kg} / \mathrm{cm}^{3}=0.004 \mathrm{~kg}$

Low: $160 \mathrm{~cm}^{2} /$ Basket*3 Baskets * $3 * 10^{-4} \mathrm{~cm} * 0.01 \mathrm{~kg} / \mathrm{cm}^{3}=0.001 \mathrm{~kg}$

5. Particulate on Scrap

High: $0.2 \mathrm{~kg} /$ assy $* 78$ assy $=15.60 \mathrm{~kg}$

Best Est: $0.02 \mathrm{~kg} /$ assy $* 78$ assy $=1.56 \mathrm{~kg}$

Low: $0.006 \mathrm{~kg} /$ assy $* 78$ assy $=0.47 \mathrm{~kg}$

6. Particulate on Fuel

High: $0.2 \mathrm{~kg} /$ assy * 162 assy $=3.24 \mathrm{~kg}$

Best Est: $0.0076 \mathrm{~kg} /$ assy * 162 assy $=1.23 \mathrm{~kg}$

Low: $0.0013 \mathrm{~kg} /$ assy * 162 assy $=0.21 \mathrm{~kg}$

7. Canister Particulate

High: 3 baskets $* 0.32 \mathrm{~kg} /$ basket $=0.96 \mathrm{~kg}$

Best Est: 3 baskets $* 0.13 \mathrm{~kg} /$ basket $=0.39 \mathrm{~kg}$

Low: 3 baskets $* 0 \mathrm{~kg} /$ basket $=0$ 


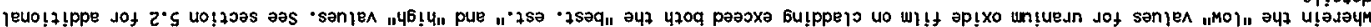

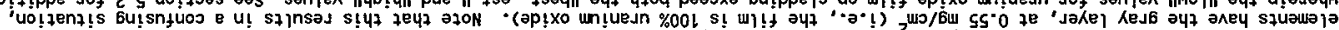

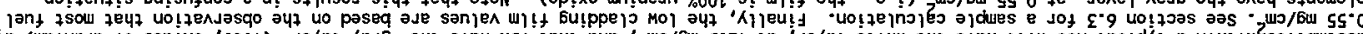

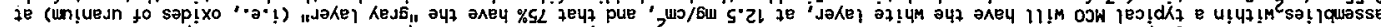

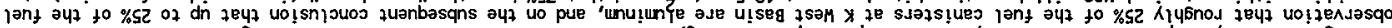

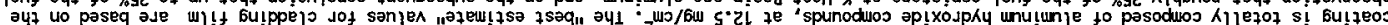

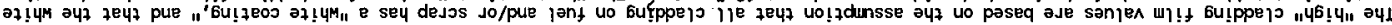

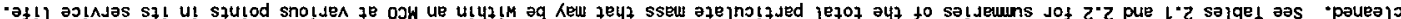

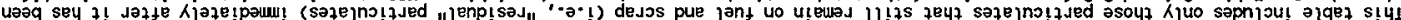

\begin{tabular}{|c|c|c|c|c|c|c|c|c|c|c|}
\hline$\overline{I I}$ & 9 & $0 \varepsilon$ & $\bar{I}$ & $\overline{99}$ & 72 & $\bar{I}$ & 9 & $8 I$ & \multicolumn{2}{|c|}{ (Б) $7 \forall 101$ OJaNnOY } \\
\hline $9 I^{*}[$ & $96^{\circ} \mathrm{G}$ & {$\left[b^{\circ} 0 \varepsilon\right.$} & $66^{\circ} 0$ & $98^{\circ} \mathrm{G}$ & $22^{\circ}+22$ & $28^{\circ} 0$ & $2 L \cdot 9$ & 50.81 & \multicolumn{2}{|r|}{ (6У) SSHW $7 \forall 10 \perp$} \\
\hline 0 & $6 \varepsilon^{\cdot} 0$ & $96 \cdot 0$ & 0 & $29 \cdot 0$ & $82 \cdot I$ & 0 & $99^{\circ} 0$ & $9^{\circ} \mathrm{I}$ & Lant & \multirow{2}{*}{ 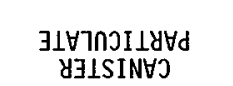 } \\
\hline 0 & 0 & 0 & 0 & 0 & 0 & 0 & 0 & 0 & dedos & \\
\hline & & & & & & & & & & \\
\hline$I 2 \cdot 0$ & $\varepsilon Z^{*} \mathrm{I}$ & $b z^{\prime} \varepsilon$ & $82^{\circ} 0$ & $69^{\circ} I$ & $2 \varepsilon^{\circ} t$ & $\mathrm{G} \varepsilon^{\prime} 0$ & so'z & $0 t^{\circ} 9$ & Lant & \multirow{2}{*}{ 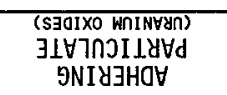 } \\
\hline$\angle B \cdot O$ & $99^{\circ} \mathrm{I}$ & $09^{\circ} \mathrm{SI}$ & $\varepsilon 2^{\cdot} 0$ & $8 L^{\circ} 0$ & $08 \%$ & 0 & 0 & 0 & dedos & \\
\hline 500.0 & & & & & & 70000 & $0000^{\circ}$ & & & \\
\hline$\frac{100^{\circ} 0}{90^{\circ} 0}$ & $\frac{600.0}{I \cdot 0}$ & $\frac{62.0}{6.0}$ & $\frac{200^{\circ} 0}{90^{\circ} 0}$ & $10^{\circ} 0$ & $\frac{2 \varepsilon^{\circ} 0}{c^{*} \cdot 0}$ & $200^{\circ} 0$ & $900^{\circ} 0$ & $\frac{00^{\circ} 0}{0}$ & $\frac{\operatorname{densc}}{\text { Lant }}$ & 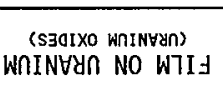 \\
\hline & & & & & & & & & & \\
\hline $82 \cdot 0$ & {$\left[2^{\circ} 0\right.$} & 0 & $8 \varepsilon^{\circ} 0$ & $82^{\circ} 0$ & 0 & $\angle t^{\circ} 0$ & $9 \varepsilon^{\circ} 0$ & 0 & 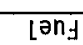 & \multirow{2}{*}{ 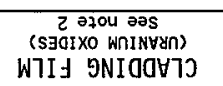 } \\
\hline$t I^{\circ} 0$ & $0 I^{\prime} 0$ & 0 & $\angle 0^{\circ} 0$ & $90^{\circ} 0$ & 0 & 0 & 0 & 0 & dens & \\
\hline & & & & & & & & & & \\
\hline 0 & $09^{\circ} \mathrm{I}$ & $6 \varepsilon^{\prime} 9$ & 0 & $\varepsilon[\cdot z$ & IG'8 & 0 & $99 \cdot 2$ & $99^{\circ} 0 \mathrm{I}$ & Lanf & \multirow{2}{*}{ 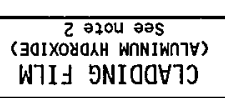 } \\
\hline 0 & $\angle L^{\circ} 0$ & $80^{\circ} \varepsilon$ & 0 & $6 \varepsilon^{\circ} 0$ & $t G^{*} I$ & 0 & 0 & 0 & dedos & \\
\hline M07 & $1 S \exists \quad 1 S \exists g$ & H9IH & M01 & IS 1 LIg & $\mathrm{HOIH}$ & M07 & LS $\exists$ LS Jg & H9IH & & \\
\hline $\begin{array}{r}S 1 \\
51 \\
\cos 2 \theta\end{array}$ & 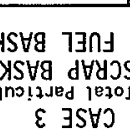 & $\begin{array}{l}\text { JyHL } \\
\text { OML } \\
\text { sutpunog) }\end{array}$ & \multicolumn{3}{|c|}{ 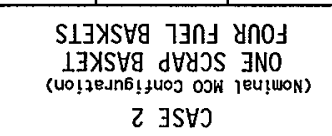 } & \multicolumn{3}{|c|}{ 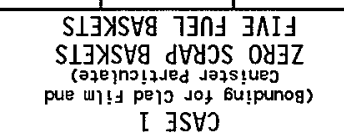 } & & \\
\hline
\end{tabular}

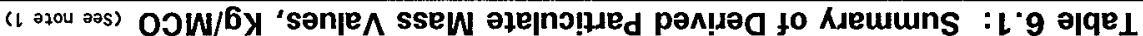


HNF-1527, Rev. 2

\subsection{REMARKS ON USE OF PARTICULATE INVENTORY VALUES}

This analysis provides estimates of residual particulates that may remain on an MCO payload immediately after cleaning. (See Tables 2.1 and 2.2 for a combined summary of residual and generated particulates that may be within MCOs at various points in their service life.) These residual particulate estimates are derived from extensive visual surveys and cataloging of spent fuel assemblies and elements in the $\mathrm{K}$ Basins, and from laboratory measured values on selected elements that were chosen on the basis of their visual examination.

It is important to recognize the evaluation is based on limited information. Key values for cladding films and adhering particulates are based on laboratory measurements that were performed on a very limited number of fuel e] ements. The basis for using these values is that the elements examined in the laboratory were selected as some of the worst encountered in the visual examination of about 500 assemblies.

Substantial conservatism is incorporated into the calculations that develop the high values. Due to the inherent variability in the geometry of fuel (damage level, character of scrap, character of particulate, etc.) and the limited amount of characterization data presently and economically available, it is not possible to develop an estimate that is based entirely on a quantitative, statistical anaTysis.

Note that the material 1isted in the tables as "adhering particulate" is not expected to be readily available for release from an $M C O$. The adhering particulate category is intended to represent only those materials that are very difficult to remove (see the fifth paragraph of section 4.6 and the 1 ast paragraph of section 5.3). This same consideration applies to the listings for oxide films on uranium. 
HNF-1527, Rev. 2

\subsection{REFERENCES}

Ba11 (1998), D. E. and Duncan, D. R., Fuel Surface Area, HNF-SD-SNF-CN-017, Rev. 3, Ju1y 1998.

Jensen (1998), L., and S. R. Wilmarth, Statistical Analysis of A7uminum Trihydroxide Thickness Data, HNF-3247, Rev. 0, August, 1998.

Kessler (1998), S. F. and Peck, S. H., Criticality Safety Evaluation Report for the $K$ Basin Fuel Retrieval Subproject, HNF-SD-SNF-CSER-010, Rev. 0, February, 1998.

Marschman (1997a), S.C., Abrefah, J., and Jenson, E.D., Highlight Report: Spent Nuclear Fuel Characterization Highlight Report, SNFCT97:006, January, 1997.

Marschman (1997b), S.C., Pyecha, and Abrefah, J., Metallographic Examination of Damaged N Reactor Spent Nuclear Fue7 Element SFEC5,4378, PNNL-11438, UC-602, August, 1997.

Pearce (1998), K. L, 105-K Basin Material Design Basis Feed Description for Spent Nuclear Fue7 Project Facilities, Volume 2, S7udge,

HNF-SD-SNF-TI-009, Volume 2, Rev. 2, September, 1998.

Pitner (1995), A. L., K East Basin Underwater Visual Fuel Survey, WHC-SD-SNF-TI-012, Rev. 0, February 1995.

Pitner (1996), A. L., K East Cleanliness Evaluation, WHC-SD-SNF-TI-018, Rev.0, January 1996.

Pitner (1997a), A. L., Visual Examinations of K East Fuel Elements, HNF-SD-SNF-TI-045, Rev. 0, February 1997.

Pitner (1997b), A. L., Visual Examinations of $K$ West Fuel Elements, HNF-SD-SNF-TI-046, Rev. 0, February 1997.

Pitner (1997c), A. L., K Basin Fuel Subsurface Examinations and Surface Coating Sampling, HNF-SD-SNF-TI-060, Rev. O, September 1997.

Pitner (1998), A. L., Summary Assessment of Fuel Damage Distributions in the K Basins, HNF-2586, Rev. 0, Apri1 1998.

Plys (1997), M.G., Fuel Surface Area Independent Estimates, FAI/97-69, Fauske \& Associates, Inc., Burr Ridge, IL, July, 1997.

Praga (1998), A. N., 105-K Basin Material Design Basis Feed Description for Spent Nuclear fuel Project Facilities, Volume 1, Fuel, HNF-SD-SNF-TI-009, Volume 1, Rev. 2, August, 1998. 
Reilly (1998), M. A., Spent Nuclear Fuel Project Technical Databook; HNF-SD-SNF-TI-015. Rev. 5, July, 1998.

Shen (1997), E. J., Fuel Retrieval System Process Validation P7an, HNF-SD-SNF-PAP-003, Rev. 0, Apri], 1997.

Sherrel1 (1998a), D. L., Spent Nuclear Fuel Inventory in Bulk MCO Water at the Cold Vacuum Drying Facility, HNF-SD-W441-CN-001, Rev. 2, August, 1998.

Sherrel1 (1998b), D. L., Post Fuel-Cleaning Corrosion of Uranium within, MCO Payloads, HNF-3048, Rev. 0, August, 1998.

Sloughter (1998), J. P., Identities of Compounds in Spent Nuclear Fuel Coatings and Particulates Sealed in Multi-Canister Overpacks, HNF-2667, Rev. 0, Apri1, 1998.

Smith (1998), K. E., Multi-Canister Overpack Design Report, HNF-SD-SNF-DR-003, Rev. 1, August, 1998. 
HNF-1527, Rev. 2

Figure I. N Reactor Mark IV Fuel Assembly.

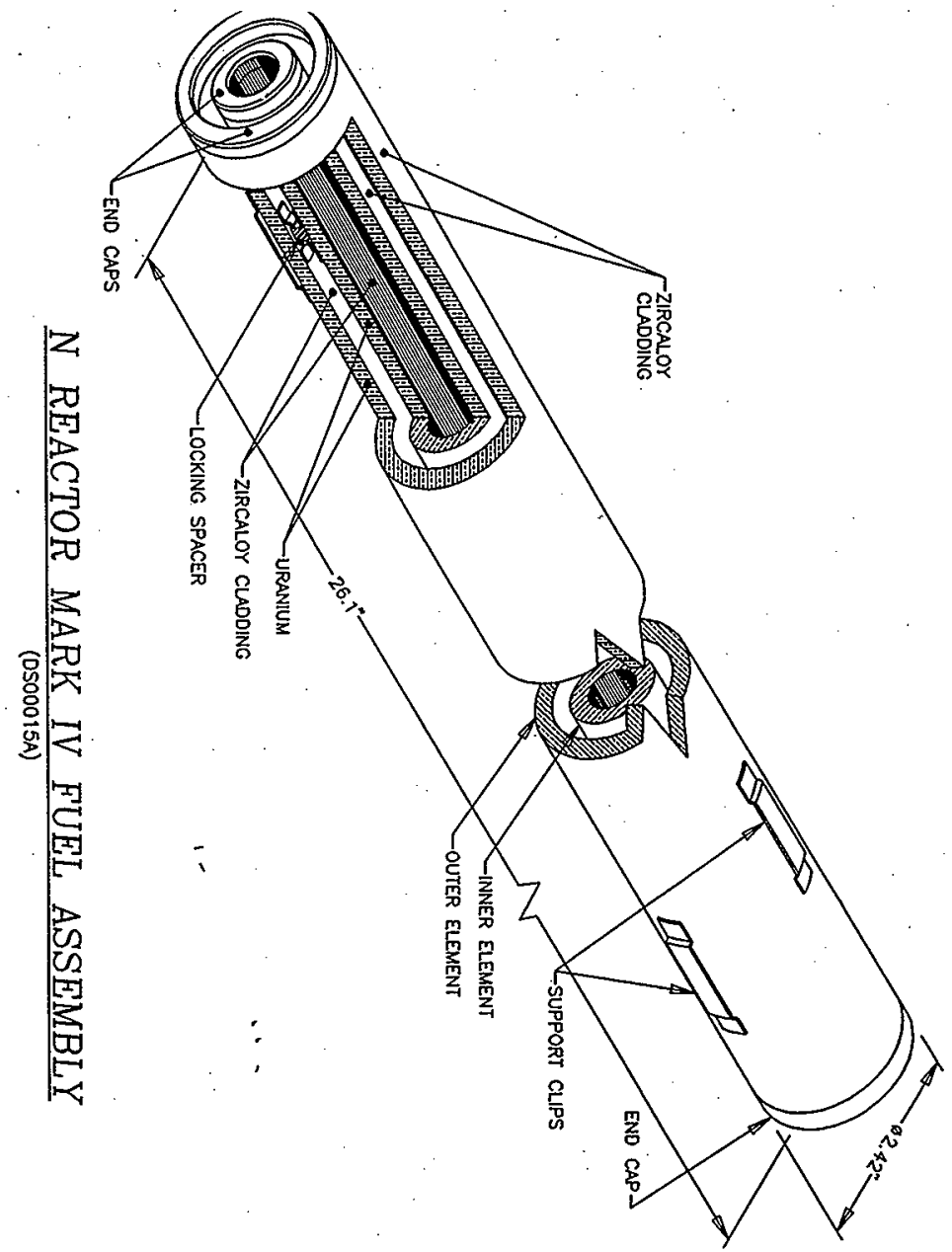


HNF-1527, Rev, 2

Figure 2. Example of a Intact Inner Fuel Element.

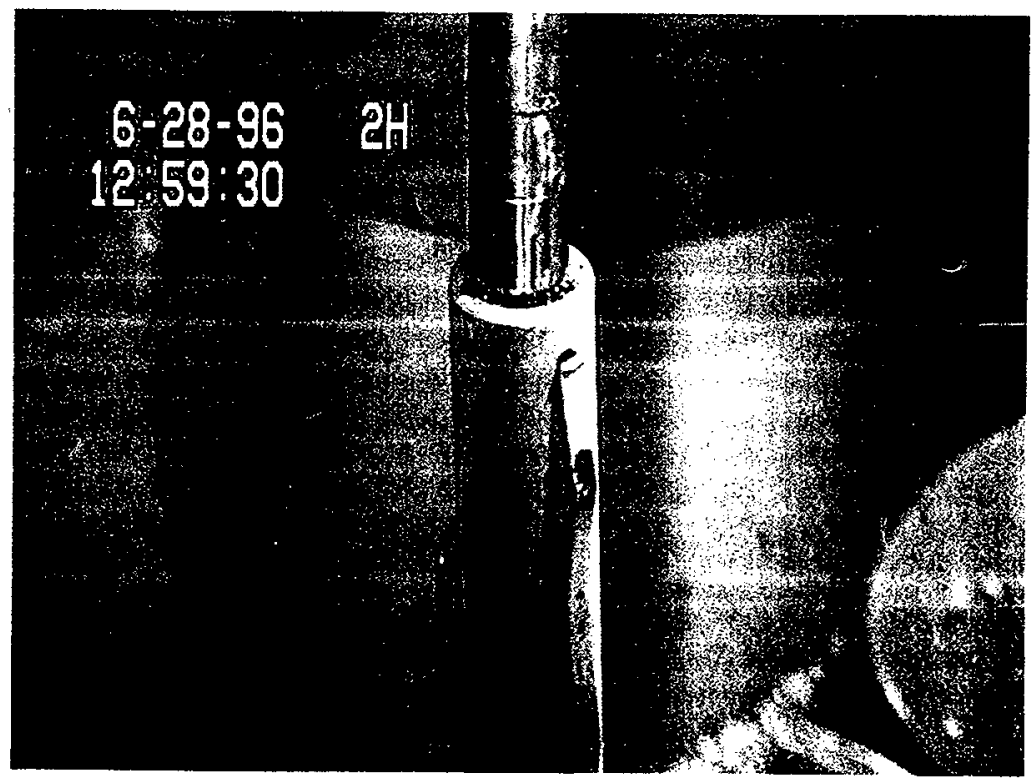




\section{HNF-1527, Rev. 2}

Figure 3. Example of a Breached Outer Fuel Element

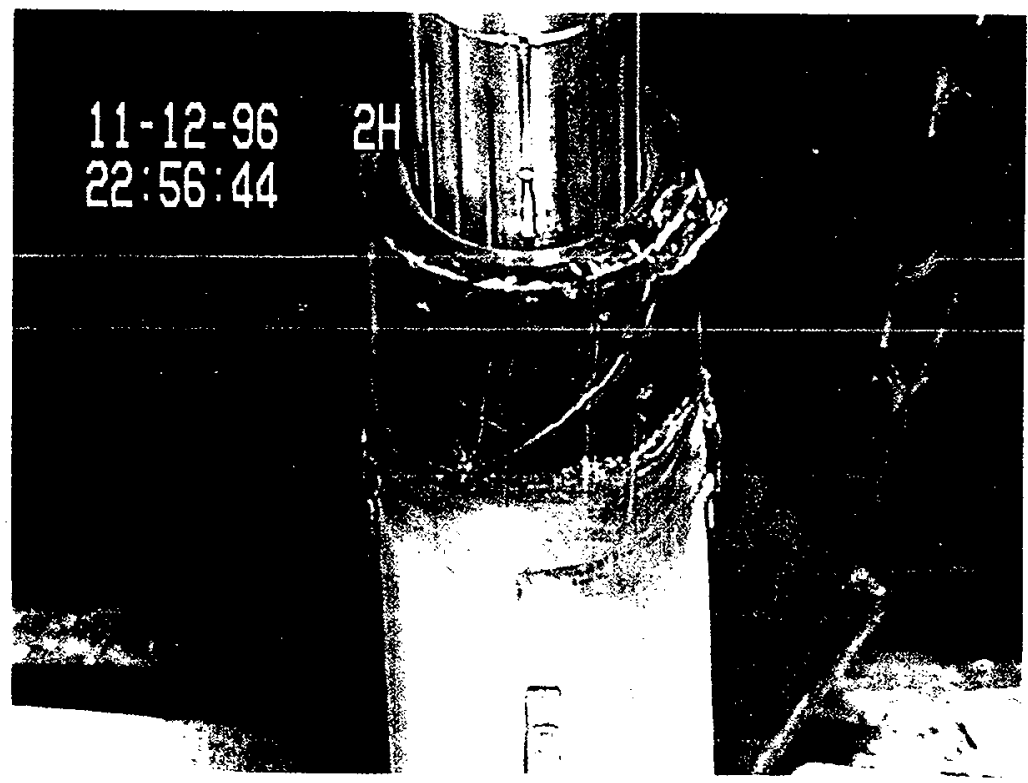


HNF-1527, Rev. 2

Figure 4. Example of a Defected Inner Fuel Element

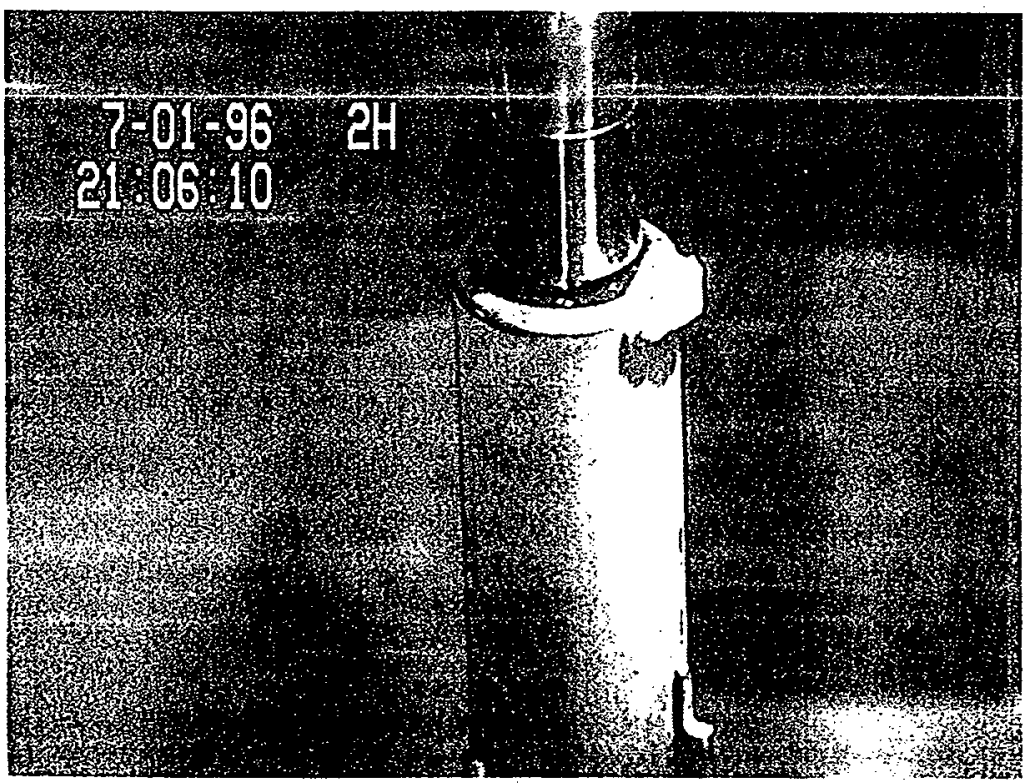


HNF-1527, Rev. 2 .

Figure 5. Bad Fuel Assemblies in K East Basin

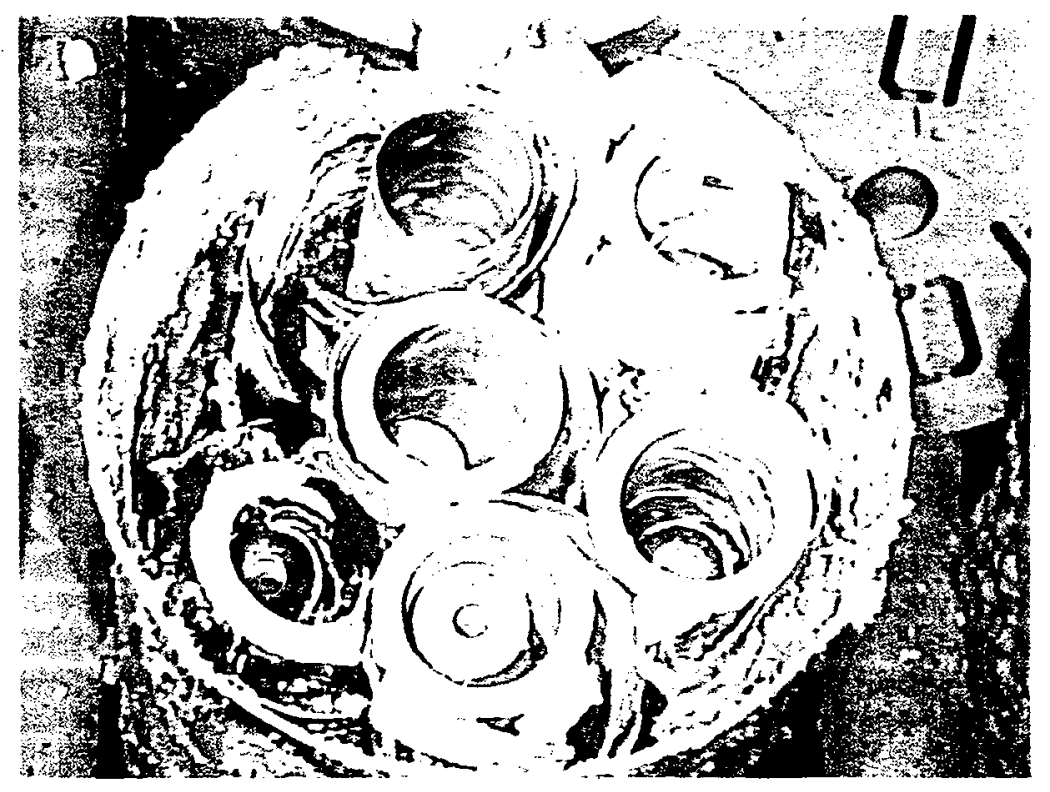


HNF-1527, Rev. 2 .

Figure 6. A Bad $K$ West Outer Fue 1 Element

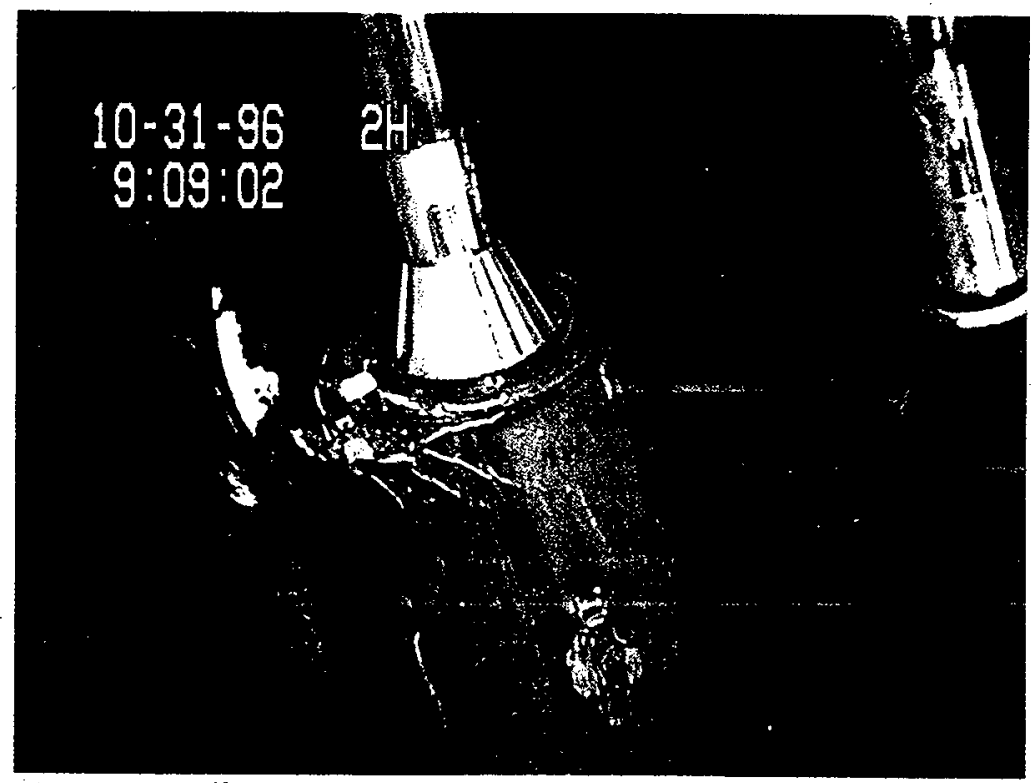


HNF-1527, Rev. 2 .

Figure 7. Sludge Cloud Trailing an Extracted Outer Fuel Element

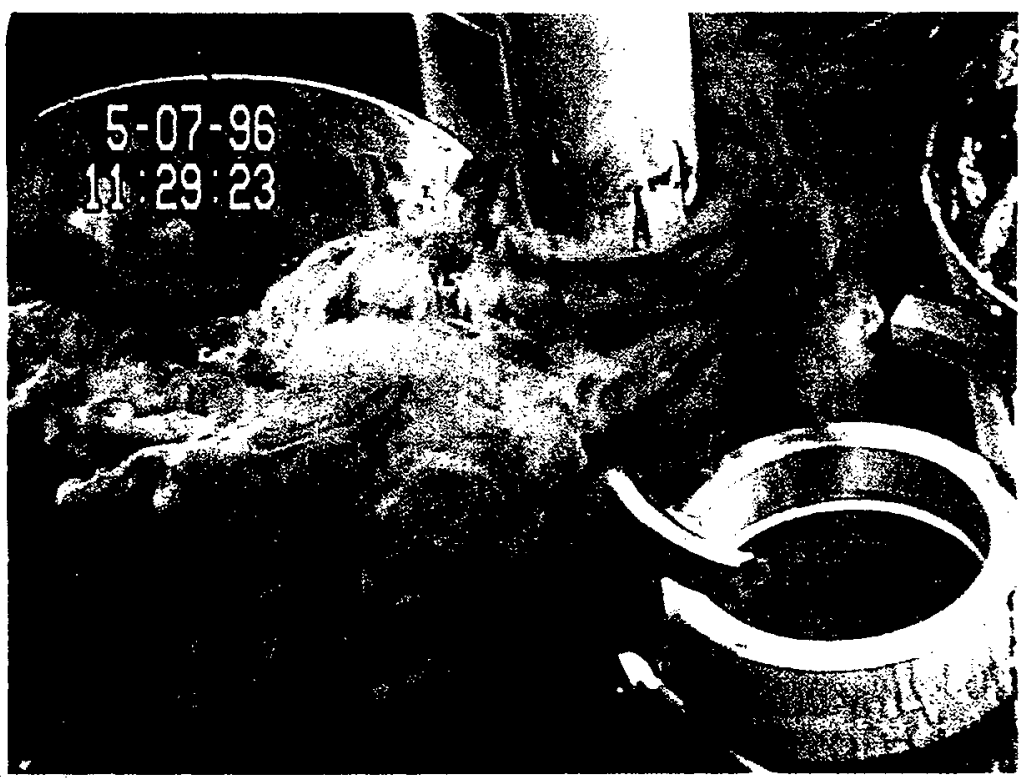




$$
\text { HNF-1527, Rev. } 2
$$

Figure 8. Surface Coating Removed by Wire Brushing

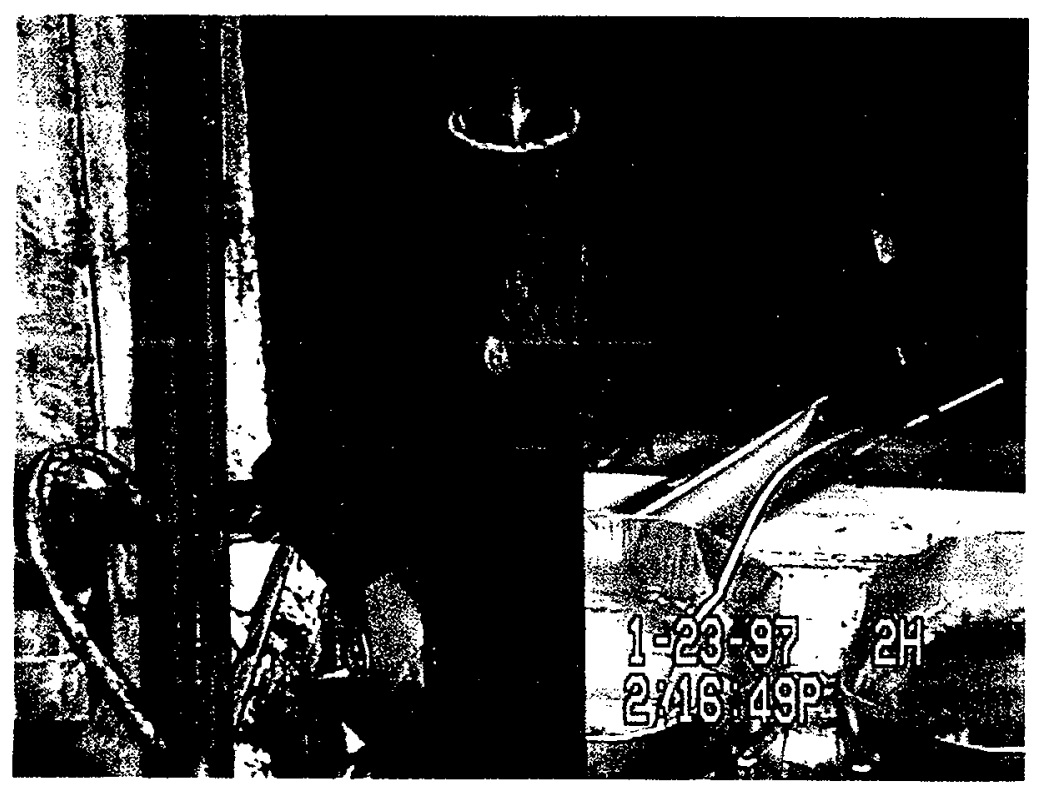




$$
\text { HNF-1527, Rev. } 2
$$

Figure 9. Heavy White Coating Found on Some K West Fuel Assemblies

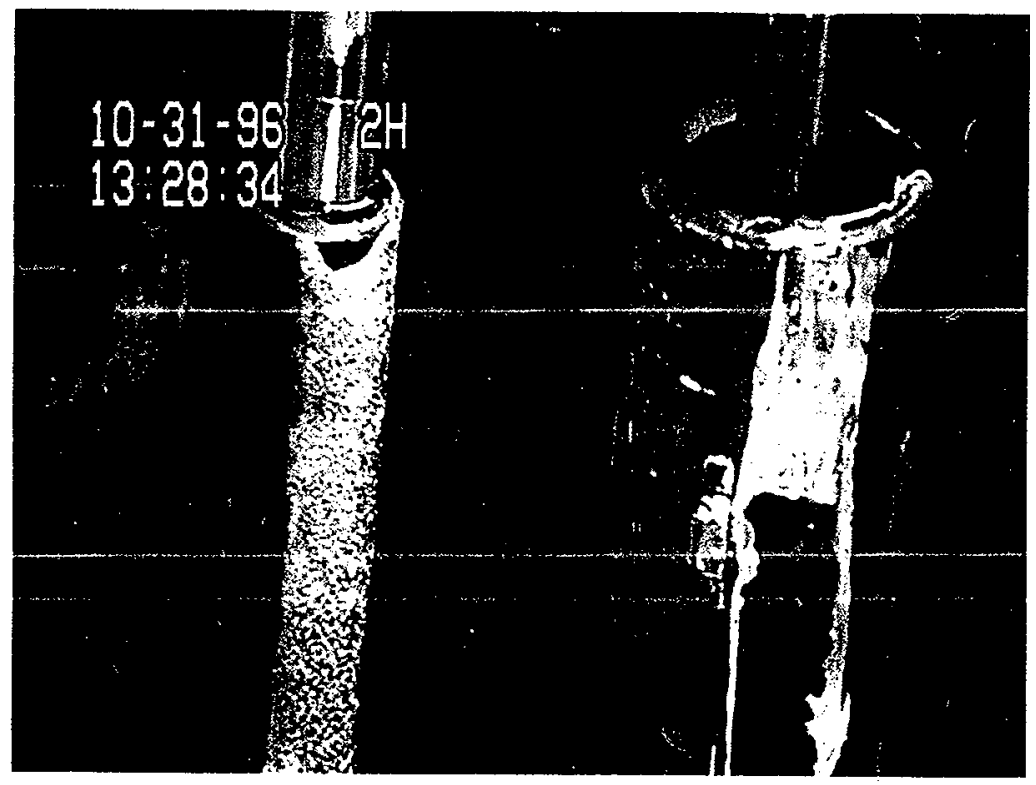




\section{HNF-1527, Rev. 2}

Figure 10. Scraping Heavy White Coating from Surface of Element.

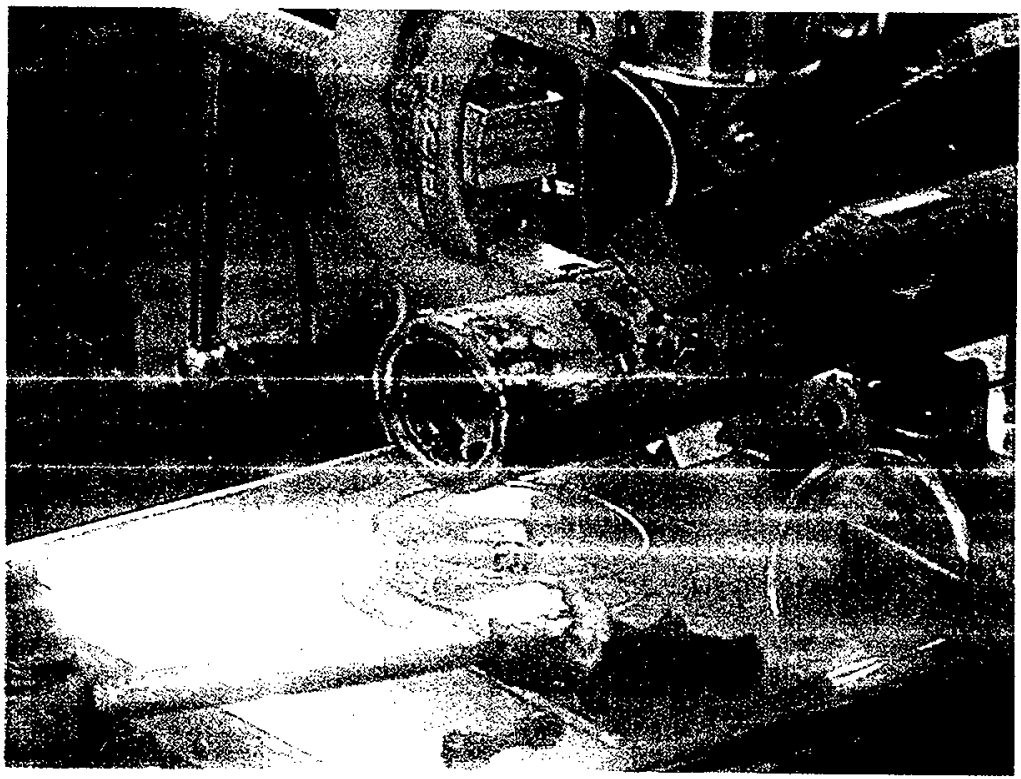


HNF-1527, Rev. 2 .

Figure 11. Total Heavy White Coating Sample Recovered.

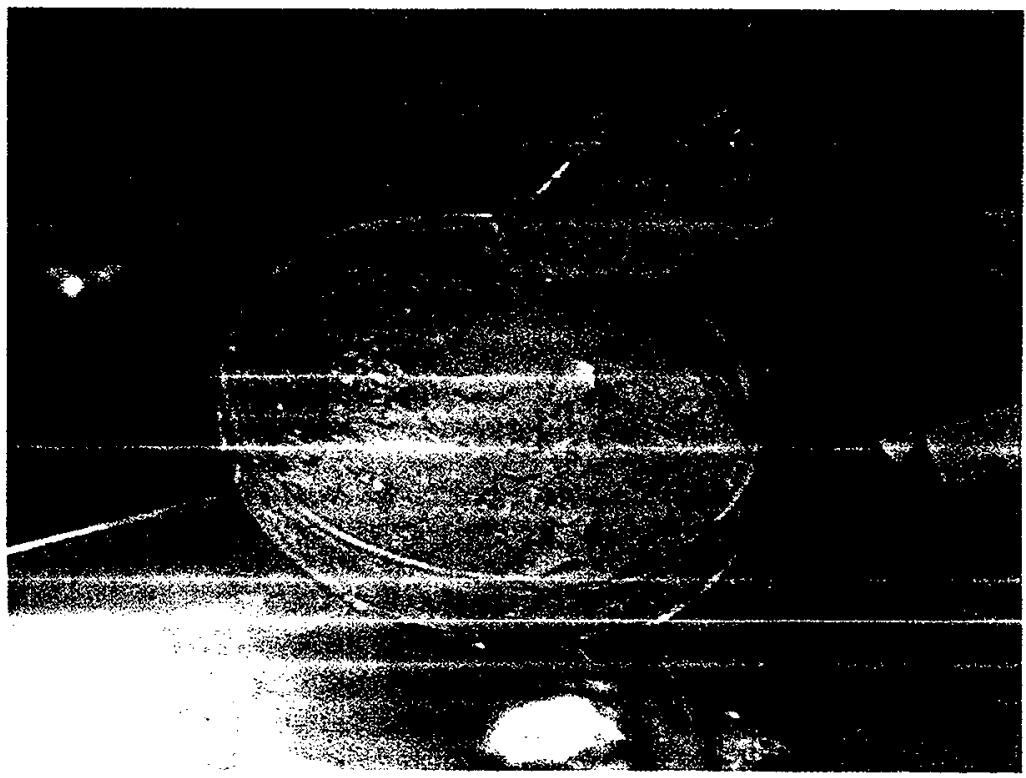


HNF-1527, Rev. 2

Figure 12. Midsection and Bottom End Damage on $K$ West Element $6743 U$.
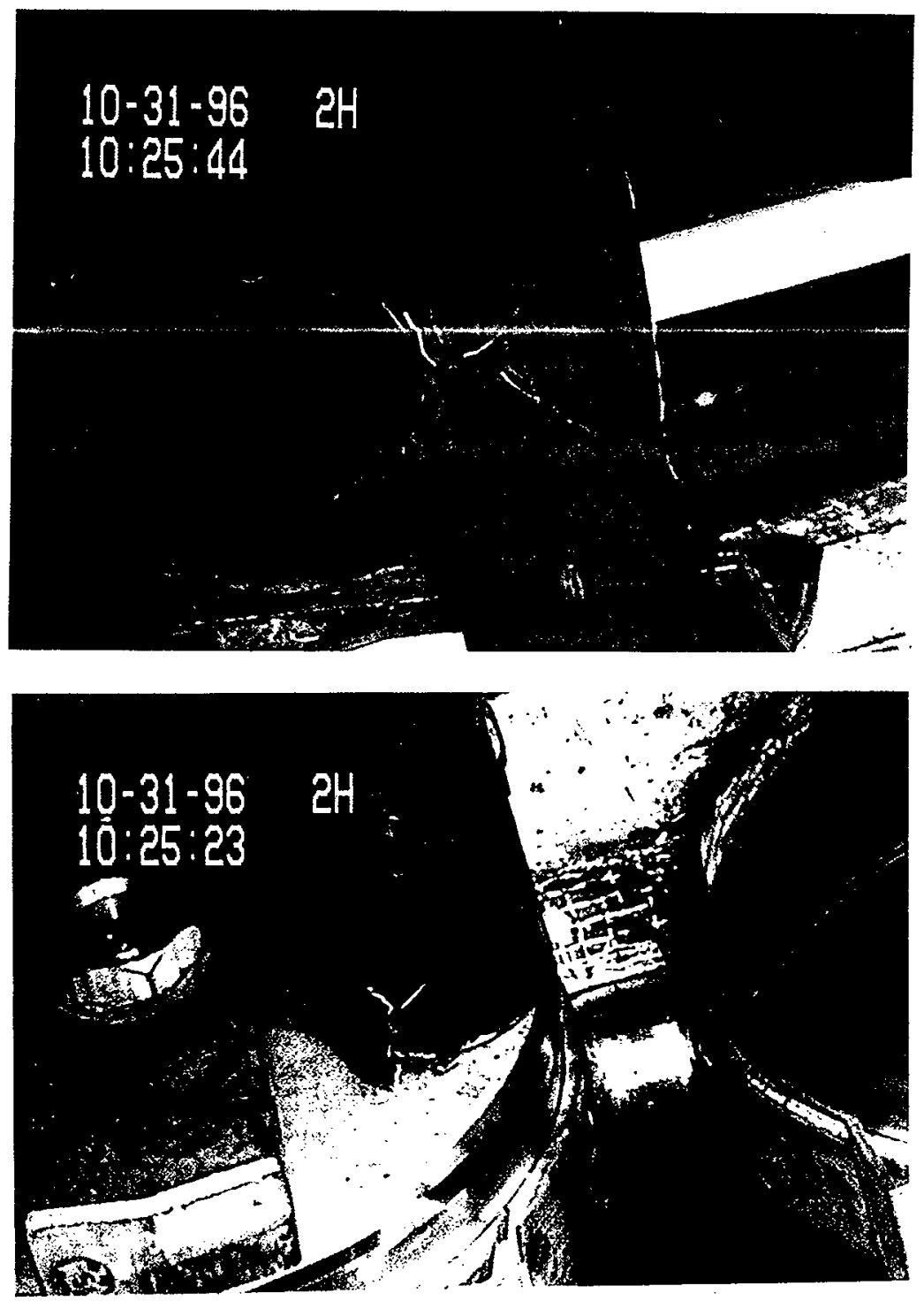
HNF-1527, Rev. 2

Figure 13. Top and Bottom Damage on K East Element 5427E.
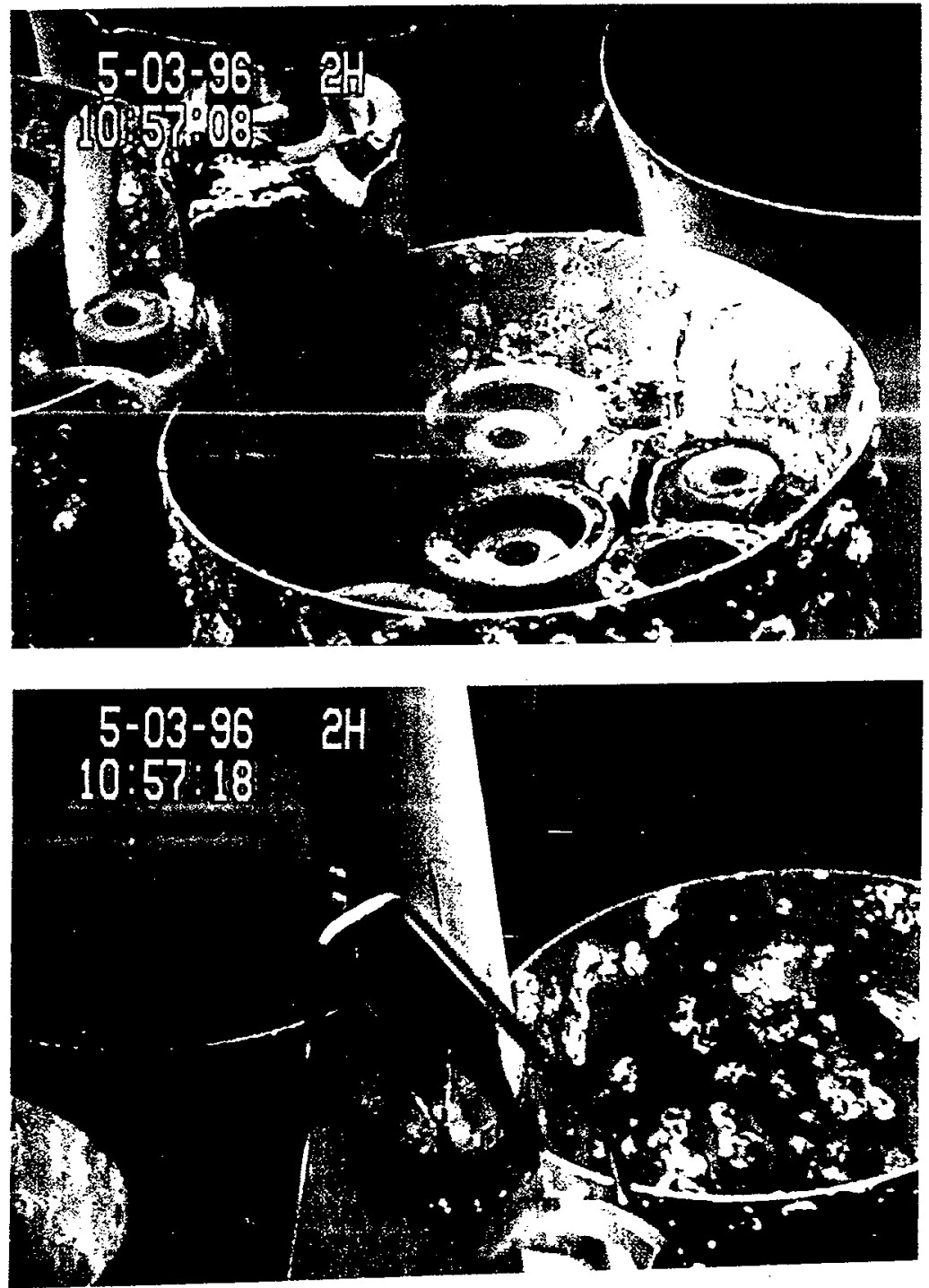
Figure 14. Open Cracks at the Midsection and Bottom of $K$ West Element 7913U.
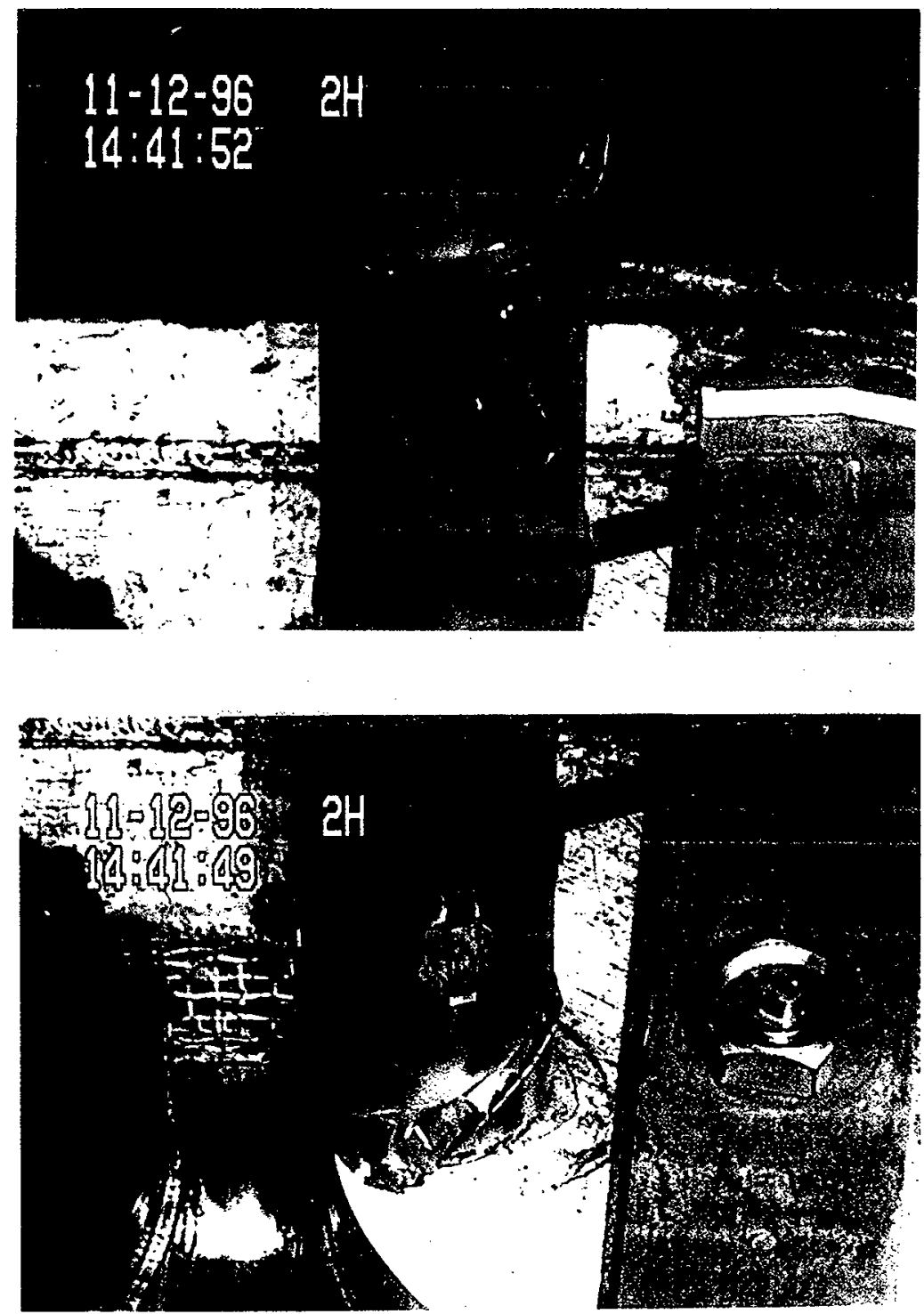
HNF-1527, Rev. 2

Figure 15. Center Damage Area on $6743 \mathrm{U}$ After Peeling and Sampling.

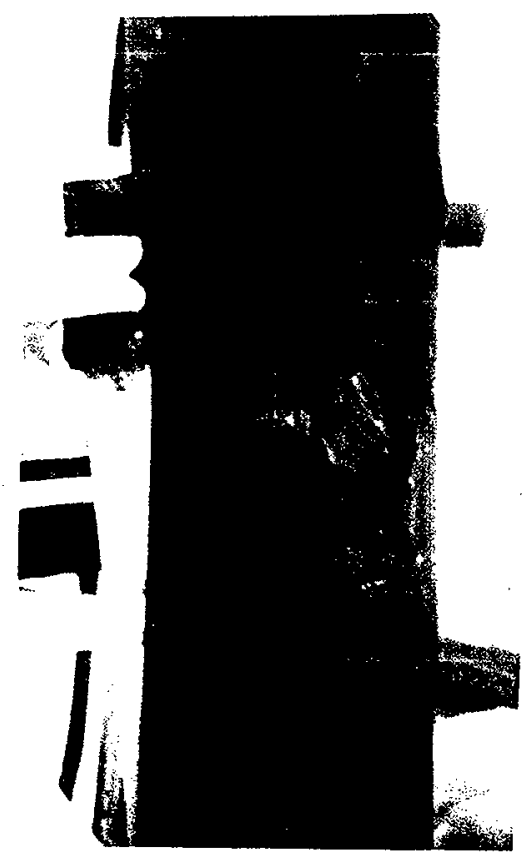


HNF-1527, Rev. 2

Figure 16. Total Particulate Sample Recovered from Top Damage Area of 5427E.

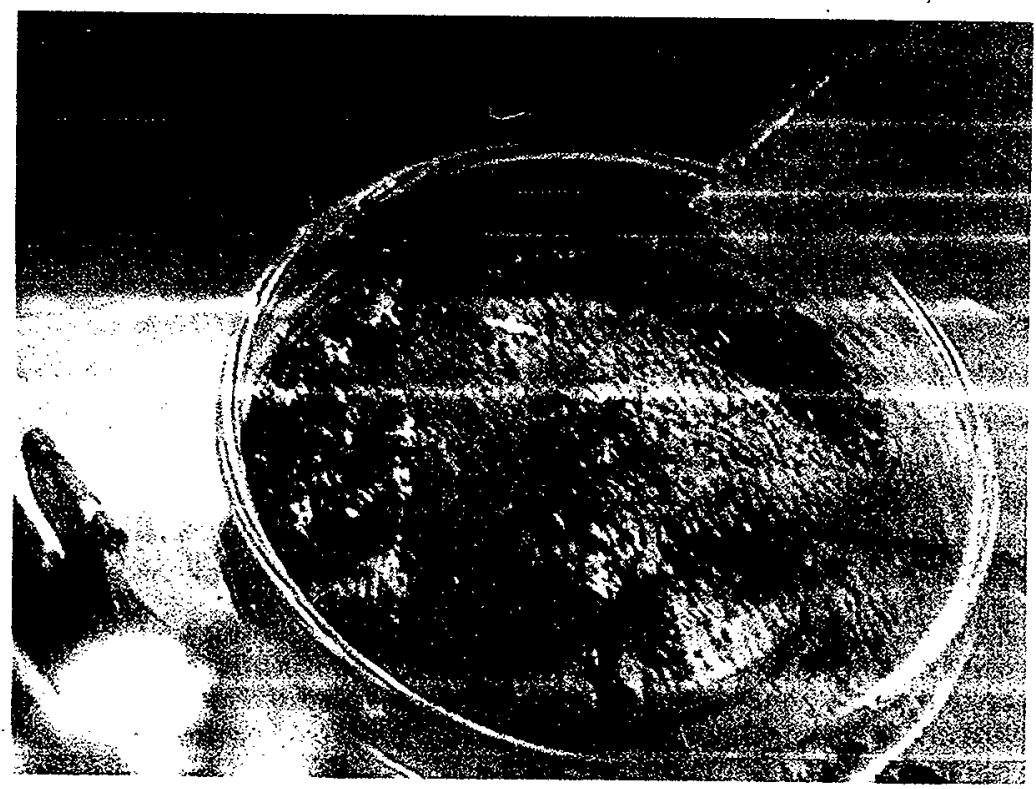


HNF-1527, Rev. 2

APPENDIX A: PANEL 
HNF-1527, Rev. 2

\section{PANEL}

As noted in Section 2.0, a panel was convened to review all available information pertinent to this subject and make judgements on the amounts of particulate that could be expected to in the MCO's.

The review panel was made up of:

Thierry Flament--Numatec Hanford Corporation, Richland, Wa

Lewis Muhlestein--ARES, Richland, Wa

A1 Pitner, DE\&S Hanford, Richland, Wa

Marty Plys--Fauske \& Associates, Burr Ridge, Illinois

Jim Sloughter-Numatec Hanford Corporation, Richland, Wa

Statements of qualifications for each of these panel members are given below.

Martin G. Plys, Fauske \& Associates, Inc.

Martin G. Plys has made several contributions to technical baseline definition and resolution for the SNFP during FY97 including the use of ignition theory to quantify the potential for fuel reactions during processing and shipping, probabalistic estimation of scrap reactive surface area, formulation of basic physical models for fuel thermal and chemical behavior, including water content, and creation and utilization of an integral simulation tool for simulation of Multi-canister Overpack processing, shipping, and staging. He has experience in application of expert judgement through participation in the FY97 Hanford flammable gas elicitation study SCOPE and authorship of the prototype SCOPE analysis tool and participation in the NRC severe reactor accident risk study NUREG-1150. He has experience in chemical reaction, flammability, fission product, and heat transfer modeling for other Hanford facilities including WESF, WRAP, and tank farms. He has contributed to and managed development and validation of the MAAP nuclear reactor severe accident analysis models used worldwide by utilities. Dr. Plys holds an SC.D. in Nuclear Engineering from MIT.

\section{A. L. Pitner - DE\&S Hanford, Inc.}

Al Pitner is a Scientist II in the SNF Fuel Characterization group of Duke Engineering \& Services, Hanford. He is responsible for the video library of characterization work performed on $\mathrm{K}$ Bas in fue 1 , and has issued several reports on observed damage distributions for the fuel stored in the basins. $\mathrm{He}$ also directed the recent hot cell examination and sampling activities conducted on fue $]$ elements transferred from $K$ Basins, and has issued a formal report on the observations and conclusions drawn from these examinations. Mr. Pitner has 25 years experience in irradiation testing of reactor fuels and materials. He graduated with honors from Washington State University with a B.S. in Physics. 
Jim Sloughter - Numatec Hanford Corporation

Jim Sloughter has extensive experience in nuclear chemical plant operation, process engineering, process design, and process development. He has experience in strontium and cesium separations and encapsulation. He developed several of the processes used to purify cesium and strontium and managed the technical aspects of a major process and equipment modification project that more than doubled capsule production rates. He managed chemica] and chemical engineering laboratories that provide process support and technology development. The Taboratories included process chemistry, actinide chemistry and engineering, analytical chemistry, chemical engineering and environmental engineering. He has been the Hanford representative on a national plutonium technology organization, and to the actinide separations conference. He chaired the senior design review team for the Purex Facility Modification Project, and been a member of several other senior design teams. He is currently a senior advisory engineer reporting to the vice president of engineering for Numatec Hanford Company. His recent experience with the Spent Fuel Project has been as a senior adviser for the basin sludge conditioning project. He defined sludge conditioning criteria and process development plans for conditioning of the $K$ Basin fuel sludge. He holds a BS degree in Chemical Engineering from the University of Idaho.

Lewis D. Muhlestein. ARES Corporation

Dr. Muhlestein has supported the SNFP for the past three years in terms of risk-based decision analysis. He was a major contributor to the risk analysis that supported the initial SNFP Recommended Path Forward. He completed the risk analysis for the evaluation of $K$ Basin sludge disposal alternatives. He has completed several uncertainty analyses relative to the fuel particulate contents of a Multi-canister Overpack (MCO), the cumulative oxygen production in an MCO, and oxygen gettering in an MCO after fuel drying. He is a major contributor to the SNFP schedule risk assessment, which is evaluating the present baseline project schedule. Dr. Muhlestein has supported several contractors (both at several DOE sites and the private sector) in regard to risk-based decision analysis. He also has an extensive background in reactor and nonreactor nuclear facility safety analysis. Dr. Muhlestein holds a Ph.D. in Physics from Iowa State University and was a professor of physics at the University of Missouri.

\section{Thierry Flament, Numatec Hanford Corporation}

Thierry Flament is the manager of the Process Engineering organization for Numatec Hanford Corporation. He has made several contributions to the Spent Nuclear Fuel conditioning projects, including review of thermal analysis, interfacing with the characterization project, definition of testing needs for the qualification of the Cold Vacuum Drying and Hot Conditioning System processes, and process and facility design review. He has also been involved with the assessment of thermal excursions in high heat waste tanks and mixer pump Effective Cleaning radius correlation to predict sludge mobilization in the waste storage tanks. He has extensive experience in France with engineering design and operational support to waste processing facilities such as vitrification and alpha contaminated waste incineration. 
HNF-1527, Rev. 2

\section{APPENDIX B: INDEPENDENT REVIEW}


HNF-1527, Rev, 2

\section{REVIEW CHECKLIST}

Document Reviewed:

ECN 648618 -- Revision 2 of HNF-1527. "Estimates of Particulate Mass in Multi-canister Overpacks."

Scope of Review:

Al1 pages where the text (other than the heading) is affected by ECN 648618 (pages $4,22,23,24,30,32,33$, and 34 ).

Yes No NA

\& $\square$

$\otimes \square \square$

* Previous reviews complete and cover analysis, up to scope of this review, with no gaps.

$\square \square \quad \square$

Problem completely defined.

Accident scenarios developed in a clear and logical manner.

ब $\square$

Necessary assumptions explicitly stated and supported.

$\square \square \quad \square$

Computer codes and data files documented.

$凶 \square \square$

Data used in calculations explicitly stated in document.

$\bowtie \square \square$

Data checked for consistency with original source information as applicable.

$\ngtr \square \square$

Mathematical derivation checked including dimensional consistency of results.

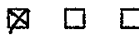

Models appropriate and used within range of validity or use outside range of established validity justified.

$\triangle \square \square$

Hand calculations checked for errors. Spreadsheet results should be treated exactly the same as hand calculations.

Software input correct and consistent with document reviewed.

$\square \square \square$

Software output consistent with input and with resuits reported in document reviewed.

Q Limits/criteria/guidelines applied to analysis results are appropriate and referenced.

Limits/criteria/guidelines checked against references.

冈 $\square \square$

Safety margins consistent with good engineering practices.

\$ $\square \quad \square$

Conclusions consistent with analytical results and applicable limits.

$\otimes \square \square$

Results and conclusions address all points required in the problem statement.

Format consistent with appropriate NRC Regulatory Guide or other standards.

* Review calculations, comments, and/or notes are attached.

\$ $\square \quad$ Document approved.

P. D. Rittmann
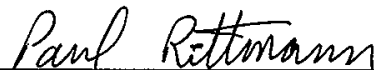

Reviewer (Printed Name and Sighature)

$10 / 20 / 98$

Date

*Any calculations, comments, or notes generated as part of this review should be signed, dated and attached to this checklist. Such material should be labeled and recorded in such a manner as to be intelligible to a technically qualified third party. 
DISTRIBUTION SHEET

\begin{tabular}{|c|c|c|c|c|c|}
\hline \multirow{2}{*}{$\begin{array}{l}\text { To } \\
\text { Distribution }\end{array}$} & \multirow{2}{*}{\multicolumn{3}{|c|}{$\begin{array}{l}\text { From } \\
\text { Process Engineering }\end{array}$}} & \multicolumn{2}{|l|}{ Page 1 of 1} \\
\hline & & & & \multicolumn{2}{|c|}{ Date $10 / 22 / 98$} \\
\hline \multirow{2}{*}{\multicolumn{4}{|c|}{$\begin{array}{l}\text { Project Title/Work Order HNF-1527, Rev } 2 \\
\text { Estimates of Particulate Mass in Multi-Canister Overpacks }\end{array}$}} & \multicolumn{2}{|l|}{ EDT No. } \\
\hline & & & & \multicolumn{2}{|c|}{ ECN No. 648618} \\
\hline Name & MSIN & $\begin{array}{l}\text { Text } \\
\text { With All } \\
\text { Attach. }\end{array}$ & Text Only & $\begin{array}{l}\text { Attach./ } \\
\text { Appendix } \\
\text { Only }\end{array}$ & $\begin{array}{c}\text { EDT/ECN } \\
\text { Only }\end{array}$ \\
\hline
\end{tabular}

D. E. Ba11

G. D. Bazinet

K. H. Bergsman

R. L. Besser

S. A. Brisbin

B. D. Lorenz

D. M. Chenault

D. R. Duncan

J. R. Frederickson

L. H. Goldmann

C. S. Haller

V. L. Hoefer

M. J. Klem

D. E. Krahn

J. J. Irwin

J. D. Mathews

R. H. Meichle

R. P. Omberg

M. J. Packer

A. L. Pajunen

M. G. Piepho

A. N. Praga

M. A. Rei17y

P. D. Rittman

R. A. Sexton

E. J. Shen

D. L. Sherrell

D. J. Sherwood

J. P. Sloughter (5)

D. W. Smith

K. E. Smith

J. A. Swenson

C. A. Thompson

J. E. Turnbaugh

SNF Project Files

DOEJRL READING RoOM

G. Banken

Q-Metrics

12025 115th Ave., NE, B1dg. D. Suite 250

Kirkland, WA 98034

M. G. Plys

Fauske \& Associates, Inc.

16 W070 W. 83rd Street

Burr Ridge, IL 60521

\section{R3-86}

$58-06$

X3-85

$\mathrm{R} 3-26$

R3-86

R3-26

R3-86

R3-86

R3-86

R3-86

R3-11

R3-85

R3-86

R3-26

R3-86

R3-86

$\times 3-79$

$\mathrm{R} 3-26$

R3-86

R3-86

R3-26

R3-86

R3-86

R3-26

R3-86

X3-75

R3-86

R3-86

$\mathrm{H} 0-34$

R3-11

R3-86

R3-11

R3-86

X3-79

R3-11

H2-53 $x$
$x$
$x$
$x$
$x$
$x$
$x$
$x$
$x$
$x$
$x$
$x$
$x$
$x$
$x$
$x$
$x$
$x$
$x$
$x$
$x$
$x$
$x$
$x$
$x$
$x$
$x$
$x$
$x$
$x$
$x$
$x$
$x$
$x$
$x$
$x$

$x$

R. D. Crowe

ARES Corp.

636 Jadwin Ave., Suite B

Richland, WA 99352

Marvin Thurgood John Marvin. Inc. 5335 W. Van Giesen Street West Richland. WA 99352 